UNIVERSIDADE DE SÃO PAULO

INSTITUTO DE GEOCIÊNCIAS

\title{
GEOCRONOLOGIA E PETROTRAMA DE QUARTZO MILONITOS DO DUPLEX TRANSCORRENTE DE LAVRAS DA MANGABEIRA
}

Marcelo de Almeida Freimann

Orientador: Prof. Dr. Carlos José Archanjo

\section{DISSERTAÇÃO DE MESTRADO}

Programa de Pós-Graduação em Mineralogia e Petrologia

SÃO PAULO

2014 


\title{
MARCELO DE ALMEIDA FREIMANN
}

\section{Geocronologia e petrotrama de quartzo milonitos do duplex transcorrente de Lavras da Mangabeira}

\author{
Dissertação apresentada ao Instituto \\ de Geociências da Universidade de \\ São Paulo para obtenção do título de \\ Mestre em Geologia. \\ Área de Concentração: \\ Mineralogia e Petrologia
}

Orientador: Prof. Dr. Carlos José Archanjo

\section{São Paulo}


Dedico àquela que me motiva nas trilhas e está nos meu dias, lembranças e projetos. À companheira arueira, Bruna. 
"Tudo que existe existe talvez porque outra coisa existe. Nada é, tudo coexiste: talvez assim seja certo..." 


\section{AGRADECIMENTOS}

Em minha concepção, esta dissertação não se resume apenas a este volume. Para o leitor distante, é provável que não vá além. Mas os que participaram dessa jornada comigo sabem que carrego, além da bagagem geológica, o amadurecimento pessoal, a convivência com memoráveis pessoas, novos amigos e o mais importante: as novas experiências. As vivências expandem a mente e alimentam nossas inquietações propositivas. Portanto, gostaria de expressar profunda gratidão:

Primeiramente agradeço ao meu orientador, Prof. Archanjo. Pela paciência mesmo nos ensinamentos mais triviais sobre a Província Borborema, terrenos que antes eram completamente novos para mim. Por ter me apontado o rumo nos momentos em que me perdi e por não ter medido esforços quando foi necessário. A amizade certamente foi essencial para tornar os dois anos e meio de mestrado mais construtivos e prazerosos. Muito obrigado!

À minha família (Ordália, Guilherme, Caroline, Rodrigo) por fomentar meus estudos e me formar como pessoa. Sabendo que todas as pessoas normais são dotadas de similar capacidade - e que neste grupo me enquadro -, concluo que são os fatores externos que realmente fazem a diferença em nossa projeção. O que seria mérito meu é, na verdade, de vocês. A vocês, portanto, devo absolutamente tudo. Muito obrigado.

À Bruna, minha companheira, agradeço todo o apoio geológico proporcionado, bem como o carinho, as risadas e acalantos - providenciais - nos momentos de ansiedade. Agradeço também aos demais da família Fiume pela torcida positiva e pelos bons momentos em São Paulo.

Ao meu tio Honório Saito, por todo o apoio nesta grande cidade. Por ser um grande exemplo de valores que deveriam ser básicos, mas que infelizmente são raros de serem encontrados nos dias atuais. Agradeço também à minha avó Helena, avô Walter, tia Aya, à Cida e à Mary Helen pelos momentos de alegria e apoio constante. Não poderia esquecer do geólogo que me apresentou esta bela ciência, a qual nos 
permite desfrutar de tantos segredos desse curioso planeta. Obrigado tio Kiitiro Masuda.

Aos amigos que fiz nesses quase dois anos e meio de USP, agradeço pelas conversas, pela diversão e apoio nos momentos que mais precisei. Obrigado pela agradável amizade e convivência: Tábata (e Aurora!), Emanuel e Rachel. A todos os amigos: Cláu Tokashiki, Muri, Soraia, Ângela, Jeane, Nazaré, Carlos, Alexandra, Natali e Nívea. Ao pessoal da GMP, Pedro Potter, Letícia, Alice, Lesado, Devassa, Fofona e Biloba, bem como aos amigos do LAMO: Rafael, PH, Bruno, Ricardo e Sandra.

Aos amigos que não são da USP, porém não menos importantes, por terem ajudado a me consolidar, desde os tempos de criança, passando pelo CPE, incluindo o departamento de geologia da UFMG e seu corpo docente (especialmente ao amigo Knauer), não-docente e discente.

Agradeço especialmente ao amigo Gustavo Viegas, que muito contribuiu com as correções e elucidações sobre a geologia estrutural, sempre com muita boa vontade, prontidão, clareza. Obrigado por tudo isso, bem como pelos dados EBSD medidos em Montpellier.

Agradeço aos professores e colegas da Alemanha pelas discussões construtivas e momentos agradáveis. Muito obrigado: Jörn Kruhl, Mark Peternell, Christian Stäb, Sakawat Hossain e Florian Steinbach. E agradeço também aos novos e verdadeiros amigos de Munique que me acolheram e que tornaram minha estadia muito mais prazerosa: Leila, René. Sem me esquecer de tia Ruth, pelo caloroso carinho nos momentos difíceis de inverno.

Por fim, agradeço às instituições que viabilizaram a realização deste trabalho: ao Instituto de Geociências da USP e seu Programa de Pós-Graduação em Mineralogia e Petrologia; à CAPES, pela bolsa que me foi concedida; e ao Banco Santander, pela bolsa-exterior concedida em parceria com a USP. 


\section{RESUMO}

FREIMANN, M.A. Geocronologia e petrotrama de quartzo milonitos do duplex transcorrente de Lavras da Mangabeiras. 2014. 83 f. Dissertação (Mestrado) - Instituto de Geociências, Universidade de São Paulo, São Paulo, 2014.

Fatias de rochas compreendendo granitóides, gnaisses bandados, anfibolitos, quartzitos e metapelitos formam um sistema imbricado situado na porção oeste do Lineamento Patos (Província Borborema, NE do Brasil). A estrutura situada no sul do estado do Ceará, inserida no Bloco Assaré, nesse momento ainda carece de estudos geológicos que permitam a sua melhor compreensão. Neste contexto, o presente trabalho foi realizado com o objetivo de trazer novos dados geocronológicos e estruturais para acrescentar no entendimento do duplex transcorrente. Datações de rochas situadas no interior das escamas imbricadas em zircões $(\mathrm{U}-\mathrm{Pb})$ via LA-ICP-MS indicam que o duplex é constituído por unidades (escamas) de idades diferentes. Gnaisses bandados, diques de anfibolito e metaultramáficas da unidade Granjeiro forneceram idades arqueanas (gnaisses: c. $2.8 \mathrm{Ga}$, LM10; c. 3.2 Ga, LM3; dique: c. 3.0 Ga, LM2). Idades siderianas e riacianas foram encontradas em gnaisses e anfibolitos a oeste de Cajazeiras (c. $2.4 \mathrm{Ga}, \mathrm{LM} 1$; c.2.4, LM13) e em augen gnaisses a sul de Cedro (c. $2.2 \mathrm{Ga}$, LM11), respectivamente. Essas sequencias do embasamento encontram-se em contato alóctone com metapelitos e quartzitos agrupados na Formação neoproterozoica Lavras da Mangabeira. Critérios cinemáticos derivados do estudo das microestruturas e das tramas cristalográficas de milonitos ricos em quartzo mostram que a sequência metassedimentar foi empurrada para nordeste. Eixos-c e eixos-<a> de quartzo indicam a ativação de sistemas de deslizamento de alta temperatura durante o desenvolvimento da trama. Estimativas de temperaturas baseadas na abertura de ângulo da trama de eixos-c e em contatos suturados entre grãos de quartzo indicam que a deformação dúctil ocorreu entre 500 e $700{ }^{\circ} \mathrm{C}$. A formação do duplex transcorrente, que constitui uma estrutura única na Província Borborema, possivelmente foi facilitada pela presença de rochas arqueanas que provavelmente se comportaram de forma mais rígida durante a deformação facilitando o cavalgamento oblíquo dos conjuntos litológicos. O arranjo estrutural das fatias imbricadas é portanto consistente com um duplex transcorrente compressivo induzido pela deformação cisalhante destral.

Palavras-Chave: duplex tectônico, Província Borborema, Ceará, geocronologia, trama cristalográfica 


\begin{abstract}
FREIMANN, M.A. Geochronology and milonites quartz fabric of the strike-slip duplex from Lavras da Mangabeira. 2014. 83 f. Dissertação (Mestrado) - Instituto de Geociências, Universidade de São Paulo, São Paulo, 2014.
\end{abstract}

Slices of metaplutonic rocks, banded gneiss, amphibolites and metasedimentary sequences form a strike-slip duplex situated in the west portion of the Patos Lineament (Borborema Province, Northeastern Brazil). U-Pb (LA-ICP-MS) data in zircons from the imbricate slices indicate they are constituted by rocks of different ages. Banded gneiss, orthogneisses and metaultramafic dikes assembled in the Granjeiro Complex yielded Archean ages between 2.8 and $3.2 \mathrm{Ga}$. In contrast, biotite gneisses and amphibolites produced a Siderian (ca. $2.4 \mathrm{Ga}$ ) age and an augen gneiss apparently intrusive in the Siderian sequences yielded a Rhyacian (ca. $2.2 \mathrm{Ga}$ ) age. These basement sequences are in allochtonous contact with metapelites and quartzites grouped in the Lavras da Mangabeira Formation of Neoprotrozoic age. Kinematic criteria deduced from the study of the microstructures and crystallographic fabric of quartz-rich mylonites show that the metasedimentary sequence was thrusted to the northeast direction. Crystalligraphic c- and a- axis of quartz indicated that medium- to high temperature slip-systems were active during the fabric development. Temperature estimations based on the opening-angle of the c-axis fabric and the sutured contacts between quartz-quartz grains indicated that the ductile deformation occurred at 500 and $700^{\circ} \mathrm{C}$. The development of the tectonic duplex was likely facilitated by the occurrence of Archean rocks involved in the shear deformation. They would have acted as a rigid (competent) material that induce the stacking of the sequences during the bulk dextral transcurrent deformation of the Patos Lineament.

Keywords: tectonic duplex, Borborema Province, Ceará, geochronology, crystallographic fabric. 


\section{LISTA DE ILUSTRAÇÕES}

Figura 1 - Localização e acesso da área em estudo (verde) por rodovias federais pavimentadas (vermelho) que atravessam os estados da Paraíba e Rio Grande do Norte. 14 Figura 2 - a) Pêra de ionização gerada em simulação de Monte Carlo; b) Formação dos cones de Kossel e linhas de Kikuchi a partir da difração dos elétrons espalhados nos planos do

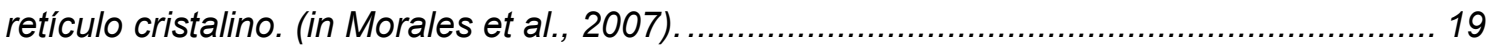

Figura 3 - Visão geral do sistema MEV-EBSD (modificado da fonte: www.dstu.univmontp2.fr/TECTONOPHY/EBSD/EBSDmeasurements.html). ......................................... 21 Figura 4 - Transformada de Hough. Os pontos claros definem bandas de Kikuchi (manual channel H.2, HKL technology; fonte: http://www.igc.usp.br/fileadmin/disciplinasweb/d78/EBSD_USP.pdf). .............................. 22

Figura 5 - Esfera de difração construída a partir de simulação numérica de padrões de difração EBSD (retirado de Schimdt \& Olesen, 1989) .................................................................. 22 Figura 6 - a) Deslizamento de um cristal por propagação de uma borda de deslocamento (dislocation glide). b) Salto de um plano de deslizamento para um nível superior ou inferior (in: Nicolas \& Poirier, 1976). 24

Figura 7 - a) A deformação intracristalina distribui deslocações com orientação sistemática pelo retículo cristalino que reflete visivelmente em extinção ondulante. b) Com a progressão da deformação mais deslocações se agrupam e formam uma banda de deformação. c) $A$ diferença de orientação entre as duas partes se acentua e mais deslocações se concentram na banda de deformação, até que esta separa completamente as duas partes e se torna a borda de subgrão. Modificado de Blenkinsop (2000). 25

Figura 8 - a) Bulging, resultado da migração da borda de um grão dentro de outro grão com uma maior densidade de deslocações. b) Recristalização por rotação de subgrão. c) Recristalização por migração de borda de grão. Modificado de Passchier \& Trouw (2005) e Stipp et al. (2002). 26

Figura 9 - Figuras de polo com padrões de OPC de eixos-c e eixos-<a> esperados em uma deformação coaxial dentro de diferentes áreas do diagrama de Flinn (modificado de Schmidt \& Casey, 1986). 29 Figura 10 - Diagrama de polos mostrando o desenvolvimento de quatro tipos de contorno de padrões de OPC de eixos-c de quatzo (cinza) e eixos-a (listrado) com o aumento do grau metamórfico em deformação progressiva não-coaxial. A variação é causada pela mudança do sistema de escorregamento dominante (retirado de Paschier \& Trouw, 2005).................... 30 Figura 11 - Gráfico com dados de ângulo de abertura de trama de eixos-c de quartzo de vs. temperatura de deformação de rochas naturalmente deformadas de diversas localidades (para localização, ver Morgan \& Law, 2004). A reta verde (estimada através de interpolação visual) permite estimar a temperatura deformacional dentro da faixa entre $300-650{ }^{\circ} \mathrm{C}$. A faixa cinza (por trás do conjunto de dados) representa a incerteza (Modificado de Law, 2014)... 31 Figura 12 - Gráfico de relação entre a temperatura (processos de recristalização) e distância ao longo do perfil em Tonale. As barras pretas verticais são os erros de estimação das isógradas de reação (retirado de Stipp et al., 2002). 32 Figura 13 - Compartimentação tectônica da Província Borborema realçando blocos crustais limitados pelas zonas de cisalhamentos e bacias metassedimentares. O destaque retângulo localiza o Bloco Assaré, foco deste trabalho. (LTB, Lineamento Trans-Brasiliano; MC, Médio Coreaú; J, Bloco Jaguaribe; RP, Rio Piranhas; SE, Seridó; C, Cachoeirinha; EP, Leste 
Pernambuco; SP, Sergipano; RPO, Riacho do Pontal; ZT, Zona Transversal e PEAL, domínio Pernambuco-Alagoas). Modificado de Van Schmus et. al.(2008).................................... 34 Figura 14 - Geologia do Bloco Assaré arquitetada por lascas imbricadas de gnaisses arqueanos e paleoproterozoicos, rochas graníticas e metassedimentares brasilianas e, por fim, coberturas sedimentares fanerozoicas (modificado do Mapa Geológico do Estado do Ceará; Cavalcante et al., 2003)............................................................................. 37

Figura 15 - Duplex de Lavras da Mangabeira situado na junção das zonas de cisalhamento destrais de Patos (PaSZ) e Tatajuba (TSZ). As zonas cisalhadas que delimitam as lentes imbricadas de maiores dimensões, à oeste, são as de Várzea Alegre (VASZ) e Faria Brito (FBSA). As demais zonas de cisalhamento são: PtSZ, Potengui; PrSZ, Portalegre; SPSZ, Senador Pompeu e JSZ, Jaguaribe (modificado de Corsini et al. 1996)............................ 40 Figura 16 - Mapa geológico do bloco Assaré (modificado do Mapa Geológico do Estado do Ceará; Cavalcante et al., 2003) e localização das amostras para análises U-Pb em zircão. 41 Figura 17 - Gnaisse bandado do Complexo Granjeiro (LM10, Fazenda Arrojado).............. 43 Figura 18 - Idades 207Pb/206Pb de zircões com zoneamento oscilatório (LM10).............. 44 Figura 19 - Diagrama concórdia $(A)$ de zircões de um ortognaisse do Complexo Granjeiro. As análises concordantes (destaque no diagrama) permitem calcular uma idade 207Pb/206Pb média $(B)$ atribuída à cristalização dos zircões. $n$, número de análises............................. 45 Figura 20 - Microfotografia do ultramafito com textura nematolepidoblástica (Tr, Tremolita; Chl, Clorita; Tlc, Talco). Aumento 10X. Polarizadores cruzados (LM2).................................. 46 Figura 21 - Diagrama concórdia de zircões de uma ultramáfica associada à gnaisses migmatíticos do Complexo Granjeiro (Povoado Mangabeira, BR-230)............................. 47 Figura 22 - Gnaisse com fino bandamento caracterizado pela alternância de faixas mais claras e escuras relativamente contínuas (BR-116, sitio Felizardo).......................................... 48 Figura 23 - Diagrama concórdia de zircões de um gnaisse bandado fino pertencente ao Complexo Granjeiro (BR-116, Felizardo). .................................................................... 49

Figura 24 - Idades 207Pb/206Pb de zircões com zoneamento oscilatório (LM1)............... 50

Figura 25 - Diagramas concórdia de zircões de um biotita gnaisse e de anfibolito (BR-230,

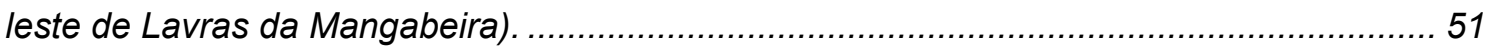
Figura 26 - Augen gnaisse com foliação definida pelo alinhamento de biotita e feldspato estirado mergulhando para sul. A foliação é cortada por dique de pegmatito. (Cedro, CE). 52 Figura 27 - Diagrama concórdia de zircões de augen gnaisse (ver localização na Figura 16).

53

Figura 28 - Localização das amostras coletadas para o estudo de trama cristalográfica no Duplex de Lavras da Mangabeira. Datum WGS 1984. Modificado do Mapa Geológico de Estado do Ceará (1:500.000; Cavalcante et al., 2003).....

Figura 29 - Trama cristalográfica de eixos-c e eixos-[a] de quartzo em medidas automatizadas de EBSD, medidas manuais de eixos-c em platina universal e esqueleto de trama das amostras analisadas. 56

Figura 30 - a) Agregado de quartzo com bordas lobadas em meio a uma matriz de granulação fina composta por feldspatos, mica branca e quartzo (LM-14); b) Subgrãos em extinção tabuleiro de xadrez, típica feição de alto grau em grão de quartzo (LM-15A); c) Estruturas pinning registrando o intenso processo de migração de bordas (LM-16); d) Porfiroclasto de microclina com estrutura manto-núcleo (LM-17); e) Textura geral mostrando ribbons paralelos à foliação em meio a grãos de quartzo com bordas lobadas (LM-18)............................... 59 Figura 31 - a) microestrutura marcada por cristais alongados de quartzo e microclina (sub)paralelos à foliação (horizontal) de muscovita. Sombra de pressão e fenoclastos assimétricos indicam cinemática com topo para ENE (LM-17); b) veio de quarto estirado com 
quartzo recristalizado obliquo ao plano de cisalhamento (horizontal) também são consistentes com topo para ENE. 61

Figura 32 - Gráfico de relação entre ângulo de abertura de trama de eixos-c de quartzo vs. temperatura estimada de deformação adaptado de Law et al. (2004) e pioneiramente proposto por Kruhl (1998). Neles encontram-se plotados os ângulos de abertura das amostras Duplex de Lavras da Mangabeira e suas respectivas temperaturas. 62

Figura 33 - Aplicação do método Krulh \& Nega (1996) em grãos de quartzo com contato suturado (numerados de 1 a 15). A relação entre o comprimento acumulado (L) vs o comprimento da régua ( $r$ ) utilizado em cada contato permite determinar a dimensão fractal e estimar a temperatura de formação da microestrutura (amostra LM-15B).....

Figura 34 - Relação r-L (escala bi-logarítmica) das bordas vetorizadas (ver Figura 33). A inclinação da reta permite calcular a dimensão fractal $D$ (ver texto). 66

Figura 35 - Gráfico de relação entre a dimensão fractal $D$ e a temperatura de formação das bordas suturadas, à esquerda, modificado de Kruhl \& Nega (1996). Os dados obtidos encontram-se em vermelho no gráfico. À direita, histograma com a distribuição normal das dimensões fractais $D$ encontradas. 68

Figura 36 - Resumo das idades U-Pb em zircão para as sequências de embasamento do Bloco Assaré. 70

Figura 37 - Perfil esquemático N-S do duplex transcorrente estruturado em flor positiva assimétrica. O mergulho da foliação cresce à medida que se aproxima da zona de cisalhamento vertical transcorrente destral de Patos (LP). No modelo proposto, a foliação converge e enraíza-se na zona de cisalhamento principal. 


\section{LISTA DE TABELAS}

Tabela 6.1 - Valores dos ângulos de abertura medidos e temperaturas estimadas através do

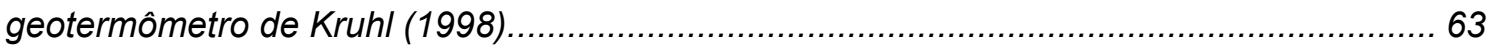

Tabela 6.2 - Resultados da dimensão fractal $D$ para cada borda e respectivo desvio padrão

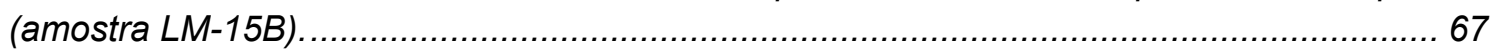




\section{SUMÁRIO}

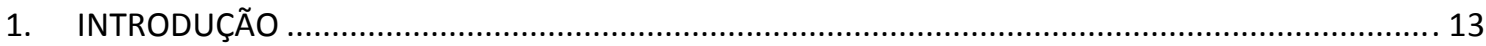

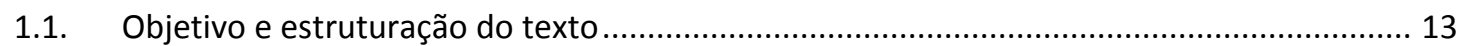

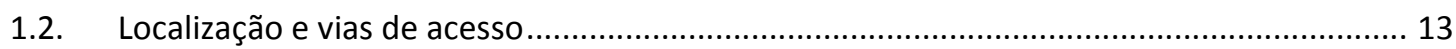

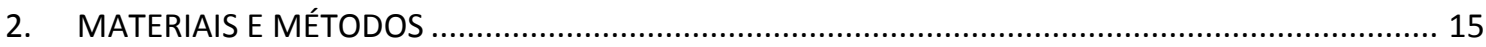

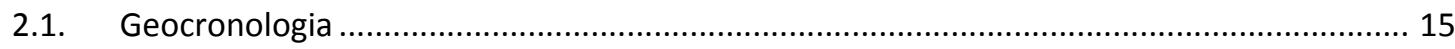

2.1.1. Separação mineral e catação manual .......................................................................... 15

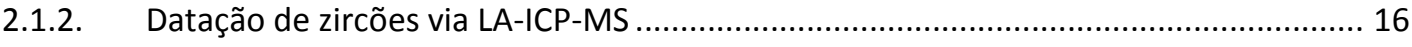

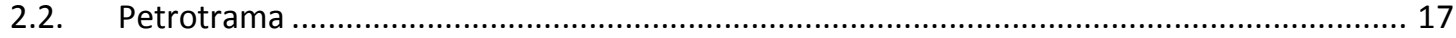

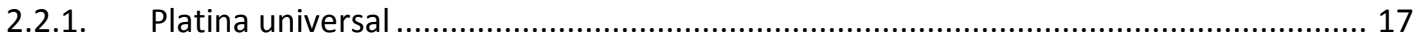

2.2.2. Difração de elétrons retroespalhados - EBSD (electron back-scattered diffraction) ... 18

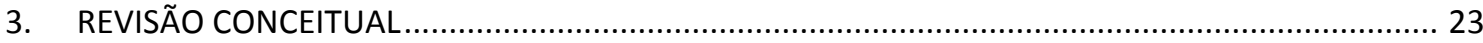

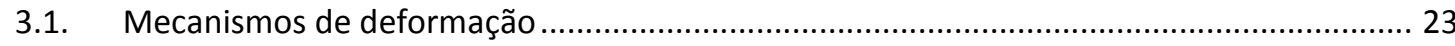

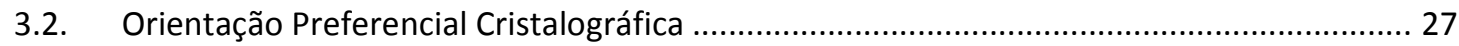

4. GEOLOGIA REGIONAL E CONTEXTO GEOLÓGICO ESTRUTURAL DA ÁREA EM ESTUDO ................. 33

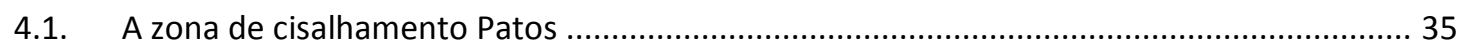

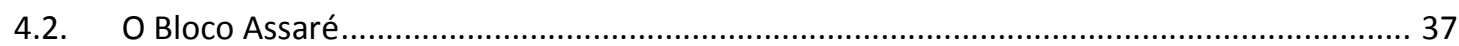

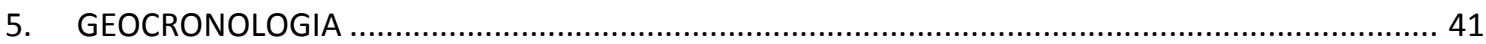

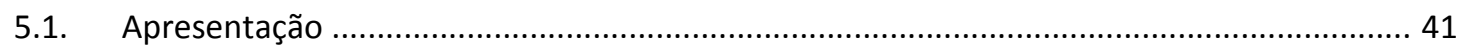

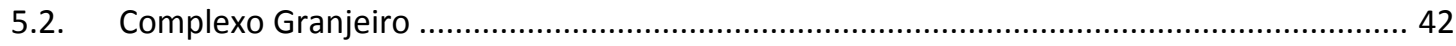

5.3. Unidade Paleoproterozoica (Grupo Caicó, Medeiros, 2008) ….............................................. 49

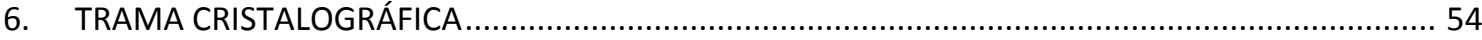

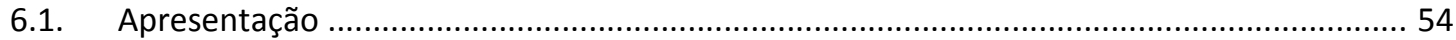

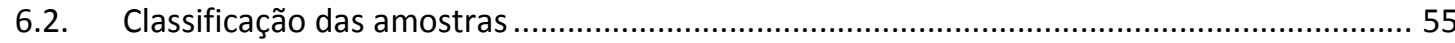

6.3. Microestruturas e interpretação da trama ...................................................................... 57

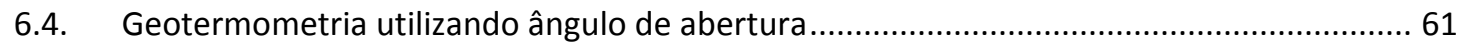

6.5. Geotermetria em bordas suturadas de grãos de quartzo................................................... 63

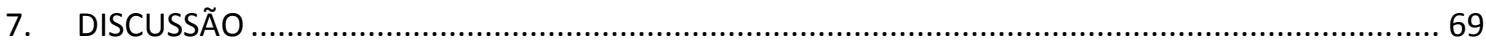

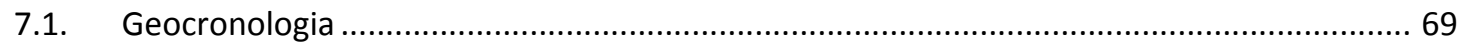

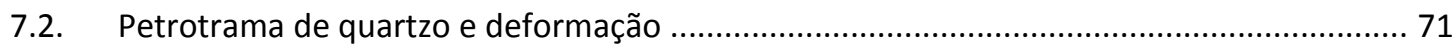

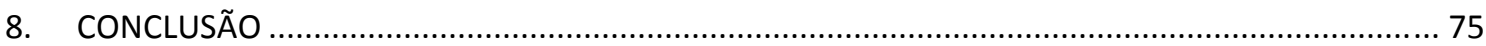

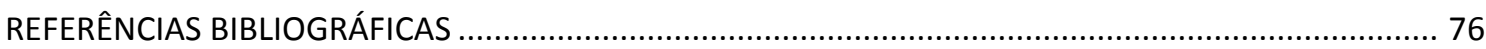

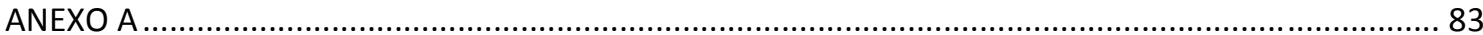




\section{INTRODUÇÃO}

\subsection{Objetivo e estruturação do texto}

O objetivo do estudo consiste (i) na caracterização geocronológica das unidades litoestruturais que compõe o duplex de Lavras da Mangabeira (Província Borborema, NE do Brasil) através da determinação das idades U-Pb em zircão, e (ii) no estudo estrutural de suas escamas imbricadas utilizando a trama cristalográfica de quartzo.

O texto está organizado inicialmente na apresentação das metodologias utilizadas compreendendo a aquisição de dados geocronológicos e a petrotrama. A fim de resgatar a teoria, é apresentada uma revisão conceitual sobre mecanismos de deformação e orientação preferencial cristalográfica (OPC), bem como uma breve introdução aos seus métodos de análise. Apresenta-se então a geologia regional da área em estudo e a contextualização geológica estrutural local.

$\mathrm{Na}$ sequência são apresentados os dados geocronológicos, a trama cristalográfica e a aplicação da geotermometria utilizando eixos-c e bordas suturadas de quartzo. A parte final da dissertação compreende a discussão e a conclusão do trabalho.

\subsection{Localização e vias de acesso}

A área estudada corresponde geomorfologicamente a feições marcadas por expressivas zonas de cisalhamento de escala regional delimitadas aproximadamente pelas latitudes $06^{\circ} 20^{\prime} 00^{\prime \prime} S$ e $07^{\circ} 10^{\prime} 00^{\prime \prime} S$ e pelas longitudes $40^{\circ} 00^{\prime} 00^{\prime \prime} \mathrm{W}$ e 38 30'00"W. Geologicamente corresponde à porção oeste do Lineamento Patos. Tomando como referência a cidade Cajazeiras (PB), pode-se acessar a área em estudo pela BR-230 na Paraíba, que une a capital João Pessoa às cidades de Patos, Pombal, Sousa e Cajazeiras. Outra possibilidade consiste em sair da cidade de Natal, 
capital no Rio Grande do Norte, em direção a Cajazeiras. O acesso principal se faz através da BR-226 passando por Currais Novos e chegando a Cajazeiras (Figura 1). Tanto saindo por João Pessoa como por Natal, a distância percorrida até a área de estudo é de aproximadamente 500 km.

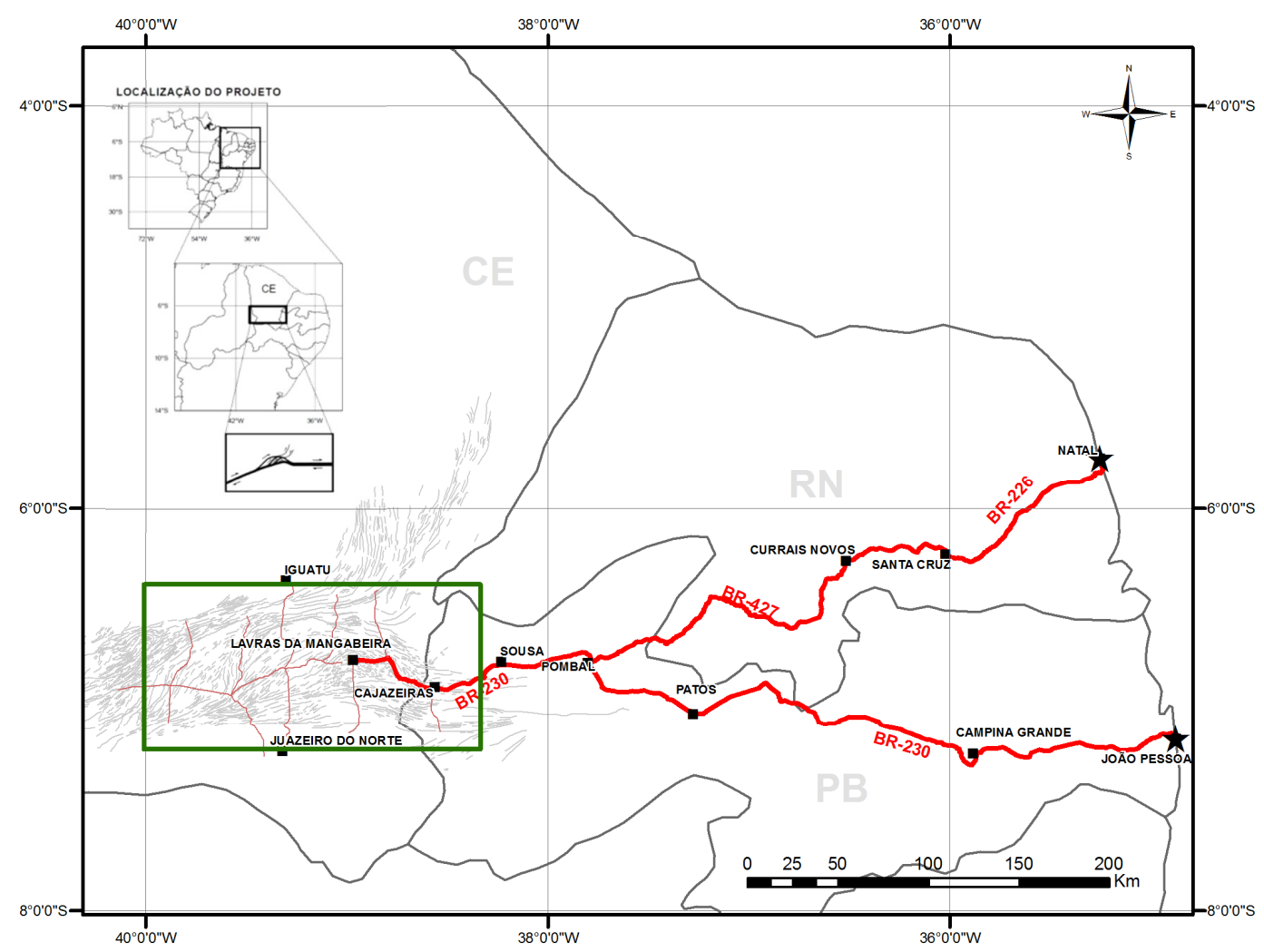

Figura 1 - Localização e acesso da área em estudo (verde) por rodovias federais pavimentadas (vermelho) que atravessam os estados da Paraíba e Rio Grande do Norte. 


\section{MATERIAIS E MÉTODOS}

\subsection{Geocronologia}

As amostras coletadas no campo para fins de estudo geocronológico foram preparadas no Laboratório de Preparação de Amostras do CPGeo-USP sob a supervisão do técnico Vasco Antônio P. Loios. A obtenção de grãos de zircão envolve as seguintes etapas:

\subsubsection{Separação mineral e catação manual}

As amostras foram primeiramente fragmentadas em um britador de mandíbulas e posteriormente pulverizadas em um moinho de disco. Malhas de Tyler permitiram separar o material pulverizado em duas frações, uma entre 100 e 250 meshes e outra $<250$ mesh. Os procedimentos para separar o zircão obedeceram as seguintes etapas:

(i) Mesa de Wiffley: o material pulverizado é lançado em uma mesa vibratória levemente inclinada que recebe um fluxo de água constante. Um sistema de canaletas separa os grãos com diferentes densidades. Os mais pesados (silicatos máficos, granada, monazita, rutilo, zircão, apatita, titanita, óxidos de $\mathrm{Fe}-\mathrm{Ti}$ ), que oferecem mais resistência ao transporte, são escoados pelas canaletas superiores enquanto os mais leves (quatzo, feldspato, micas) seguem pelas inferiores. Duas canecas dispostas adequadamente na lateral da mesa coletam os grãos mais pesados e os leves. $O$ material segue para a secagem sob bulbo incandescente.

(ii) Separação magnética: após a secagem da fração de maior densidade, a magnetita é retirada da amostra com o auxílio de um ímã de mão. Em seguida o material é colocado no separador magnético Frantz sob uma corrente de 0,4 A que fraciona a amostra em uma porção magnética e outra não magnética; nesta última estão concentrados os zircões. 
(iii) Líquidos densos (bromofórmio - $\mathrm{CHBr}_{3}$ ): a fração não magnética é inserida em um funil de vidro contendo bromofórmio. Os grãos mais densos que 2,85 g/cm3 são decantados no funil enquanto os menos densos continuam em suspensão. Os grãos pesados e leves são recolhidos em filtros, lavados com álcool, secados e estocados em recipientes vedados. A fração interessante é a portadora de minerais densos, já que o zircão possui densidade aproximada de $4,6 \mathrm{~g} / \mathrm{cm} 3$.

(iv) Líquidos densos (iodeto de metileno $-\mathrm{CH}_{2} \mathrm{I}_{2}$ ): a fração densa não magnética separada no bromofórmio é inserida em um funil de vidro contendo iodeto de metileno. Os grãos mais densos que $3,8 \mathrm{~g} / \mathrm{cm} 3$ são decantados no funil enquanto os menos densos continuam em suspensão. Ambas as classificações são recolhidas em filtros, lavadas com acetona, secadas e estocadas em recipientes vedados (o item (iv) é uma repetição do (iii)).

(v) Catação manual: após a obtenção do concentrado de minerais pesados e não magnéticos, prossegue-se para a catação manual. Considerando que no concentrado ainda deva existir minerais pesados diversos como apatita, titanita e sulfetos, é necessário separar visualmente os grãos utilizando lupa binocular. Foram selecionados entre 60 e 16 zircões (este último na amostra LM11), com exclusão daqueles com alto grau de fraturamento interno, feições de metamictização ou inclusões.

\subsubsection{Datação de zircões via LA-ICP-MS}

Após polimento, os grãos são imageados utilizando um microscópio eletrônico de varredura (MEV) com detector de luminescência. As análises isotópicas foram realizadas em um ICP-MS multicoletor Neptune (Thermo Scientific) com laser de Ar$\mathrm{F}$ e diâmetro do spot de $29 \mu \mathrm{m}$. As intensidades isotópicas de ${ }^{202} \mathrm{Hg},{ }^{204} \mathrm{Pbcomum}$, ${ }^{206} \mathrm{~Pb},{ }^{207} \mathrm{~Pb},{ }^{208} \mathrm{~Pb}$ e ${ }^{238} \mathrm{U}$ foram adquiridos em 50 ciclos de $1 \mathrm{~s}$, obedecendo a sequência de medida do branco, análises de padrão internacional GJ-11 (idade média de $601 \pm 3.5 \mathrm{Ma}$ ) e análises dos cristais. Maiores detalhes sobre o procedimento analítico podem ser encontrados em Sato et al. (2009).

A escolha de setores do grão para análise pontual foi direcionada às regiões

mais limpas possíveis, evitando-se áreas fraturadas e setores de aspecto metamitizado. As razões isotópicas foram plotadas no diagrama concórdia, com o 
cálculo dos parâmetros estatísticos obtidos no programa ISOPLOT v.3 (Ludwig, 2003). Tanto quanto possível 0 erro analítico das idades foi calculado para $2 \sigma$ (aproximadamente $95 \%$ de confiança). No entanto, para manter o grau de coerência das análises dentro um valor aceitável (MSWD $\leq 5.0$ ), algumas idades estão indicadas para $1 \sigma$.

\subsection{Petrotrama}

\subsubsection{Platina universal}

Para esta etapa foram preparadas 6 seções delgadas de quartzo milonito pertencentes ao Duplex Lavras da Mangabeira. As amostras foram estudadas no plano perpendicular à foliação $(X Z$, onde $X>Y>Z)$ e na direção da lineação de estiramento $(=X)$ do elipsoide de deformação finita.

As medições manuais de eixos-c foram realizadas integralmente no Laboratório de Óptica do IGc-USP utilizando uma Platina Universal de quatro eixos acoplada a um microscópio óptico convencional. Os procedimentos utilizados nas medições são detalhadamente descritos em Wahlstrom (1969) e Santoro (1998).

As orientações dos eixos-c de quartzo estão plotadas em redes de SchmidtLambert projetados no hemisfério inferior. O padrão da trama cristalográfica é apresentado tendo o eixo principal intermediário -Y- de deformação finita na vertical e os eixos X e Z paralelos às direções $E-W$ e N-S, respectivamente. A foliação milonítica e a lineação de estiramento são tomadas como referência e representadas na rede como um plano (achatamento principal vertical $X Y$ ) e uma linha horizontal paralelo ao eixo $\mathrm{X}$, respectivamente. 


\subsubsection{Difração de elétrons retroespalhados - EBSD (electron back-scattered}

diffraction)

O método de difração de elétrons retro-espalhados em um microscópio eletrônico de varredura (MEV-EBSD) fornece o mapeamento completo dos padrões de orientação cristalográfica de agregados poliminerálicos ou grãos individuais sem perder a correlação direta com a microestrutura observada, no caso de rochas deformadas.

A orientação da rede cristalina em rochas deformadas para o estudo da OPC (orientação preferencial cristalográfica) pode ser obtida tanto por medição em um único grão ou por estatística em experimentos de difração (medidas em volume de textura). Os últimos incluem métodos como difração de raio-x ou difração de nêutrons (Wenk et al., 1984, 1986). Medidas em único grão são baseadas na determinação pontual da orientação de direções da rede cristalina ou na completa orientação de cristais individuais em uma amostra. Outros métodos se baseiam na microscopia óptica utilizando a platina universal (e.g. Berek, 1924) e a platina do microscópio, auxiliados por computadores, como CIP (computer-integrated polarization microscopy - Heilbronner \& Pauli, 1993) ou fabric analyser (Wilson et al., 2003, 2007). Todos os métodos citados possuem vantagens em casos específicos, bem como restrições. $A$ técnica EBSD é a maneira mais fácil de adquirir grandes números de dados completos de OPC de minerais individuais.

O princípio da técnica MEV-EBSD é baseado na interação entre feixe de elétrons e superfícies cristalográficas sólidas. Quando um feixe de elétrons atinge a amostra, os elétrons descrevem trajetórias diversas, formando um volume de interação denominado "pêra de ionização" (Figura 2a). Deste volume, uma parcela considerável de elétrons não perde energia significativa, sofrendo o retroespalhamento elástico e apenas mudando a direção ao longo da superfície da amostra.

A interação entre uma superfície cristalográfica fortemente inclinada com o feixe de elétrons causa uma fonte virtual de elétrons retro-espalhados, sendo possível descrever sua trajetória como se fosse emitido de uma fonte pontual, situada dentro da pêra de ionização, próximo à superfície. Os elétrons que escapam da amostra em 
direção à superfície, espalham-se coerentemente nos planos cristalinos sofrendo a difração, que produz dois cones conhecidos como cones de Kossel (Figura 2b). A interação dos elétrons retro-espalhados para formar os dois cones obedece a Lei de Bragg (i):

$$
n \lambda=2 d_{h k l} \sin \theta(\mathrm{i})
$$

onde $n$ é a ordem de reflexão, $d_{h k l}$ a distância interplanar (hkl), $\theta$ o ângulo de Bragg (ângulo de incidência) e $\lambda$ o comprimento da onda ligada à tensão de aceleração dos elétrons.

A intersecção dos elétrons retro-espalhados projetados com a tela de fósforo formam linhas ou faixas denominadas bandas de Kikuchi (Figura 2b). Estas linhas possuem padrão paralelo e têm uma largura distal de cerca de $2 \theta$. Dessa forma, diferentes bandas constituem diferentes padrões de difração de elétrons retroespalhados em uma família de planos reticulares. A linha mediana dos cones representa o plano cristalino que difratou o feixe e a intersecção entre as linhas de Kikuchi, uma direção cristalográfica. Este padrão, portanto, constitui o cerne do método EBSD (Lloyd et al., 1987; Prior et al., 1999; Higgins 2006).
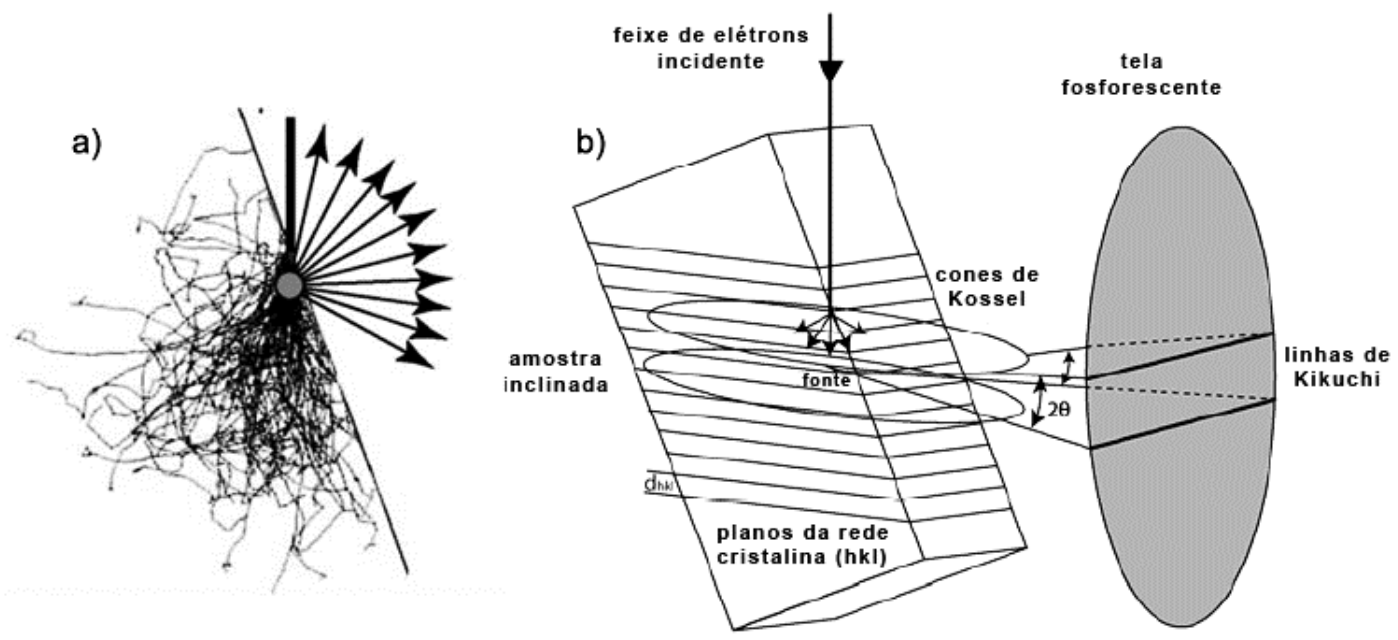

Figura 2 - a) Pêra de ionização gerada em simulação de Monte Carlo; b) Formação dos cones de Kossel e linhas de Kikuchi a partir da difração dos elétrons espalhados nos planos do retículo cristalino. (in Morales et al., 2007). 


\section{Instrumentação e procedimentos analíticos}

Para obter os padrões de difração, é necessário a inserção de uma tela fosforescente que impacte os eletros difratados, dentro da câmera de vácuo do MEV. Um feixe de elétrons emitidos pelo MEV atinge a amostra posicionada em uma superfície que faz um ângulo de $\sim 70^{\circ} \mathrm{com}$ a horizontal $\left(20^{\circ} \mathrm{com}\right.$ o feixe). Essa inclinação é adotada de forma a restringir a penetração no feixe de elétrons na amostra, diminuindo assim as colisões inelásticas e aumentando a probabilidade de espalhamento dos elétrons na superfície da amostra. A tela fosforescente recebe os elétrons retro-espalhados e a interação entre os mesmos gera uma figura de difração (padrão de difração). Uma câmera de captação de baixas luminosidades ( $C B L)$ acoplada ao MEV, externa ao vácuo, captura a imagem do padrão de Kikuchi através de uma janela de quartzo e a converte digitalmente em uma imagem de maior resolução a fim de minimizar os ruídos. Uma síntese do sistema analítico está representada na Figura 3.

O padrão de difração obtido é indexado e comparado com a base de dados minerais dos softwares de tratamento das imagens de difração com o objetivo de obter as informações cristalográficas da amostra analisada (Schimdt \& Olesen, 1989; Prior et al., 1999; Randle \& Engler, 2000).

O mecanismo de indexação dos padrões de difração se dá a partir do reconhecimento automatizado da largura das linhas de Kikuchi e das intersecções entre linhas de Kikuchi (eixos cristalográficos) por um software. 


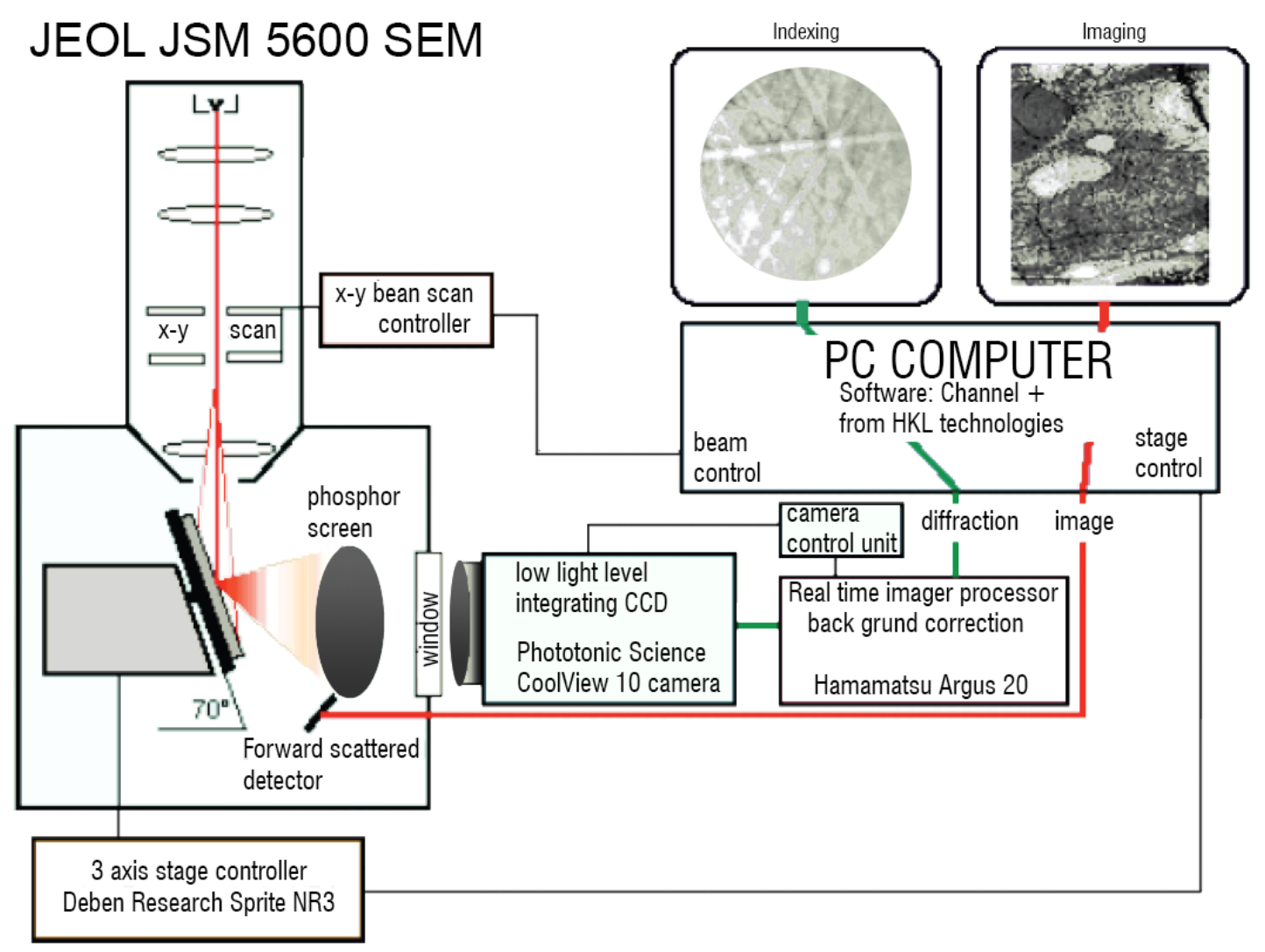

Figura 3 - Visão geral do sistema MEV-EBSD (modificado da fonte: www.dstu.univmontp2.fr/TECTONOPHY/EBSD/EBSDmeasurements.html).

\section{Indexação das figuras de difração}

As orientações dos eixos cristalográficos extraídos da intersecção entre as linhas de Kikuchi são determinadas de forma automatizada a partir da transformada de Hough (1962). Esse procedimento consiste em transformar os padrões simples de intersecção de linhas em pontos claros, os quais são facilmente reconhecíveis pelo computador a partir do algorítimo de detecção de bandas (Figura 4). O software utiliza um modelo de esfera construído através da simulação numérica de EBSPs (electron back-scattered pattern) para comparar com a figura de difração obtida e determinar as orientações cristalográficas do cristal (Figura 5). 

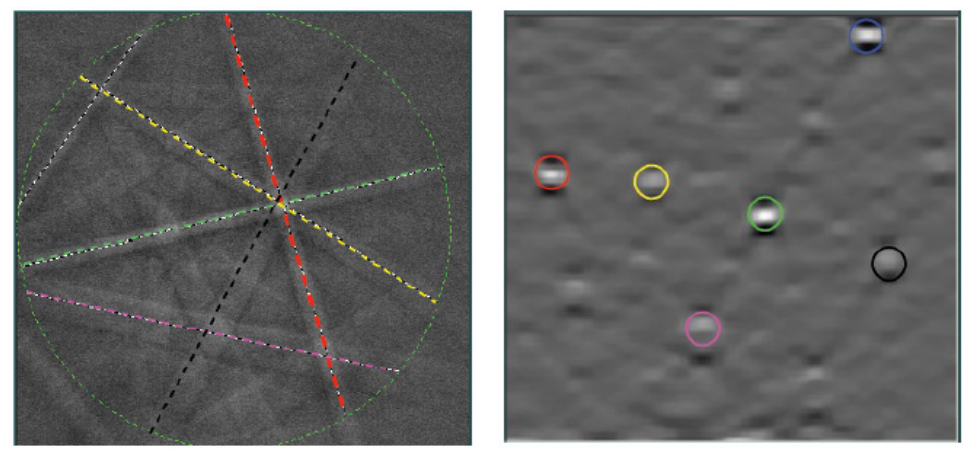

Figura 4 - Transformada de Hough. Os pontos claros definem bandas de Kikuchi (manual channel 4.2, HKL technology; fonte: http://www.igc.usp.br/fileadmin/disciplinasweb/d78/EBSD_USP.pdf).

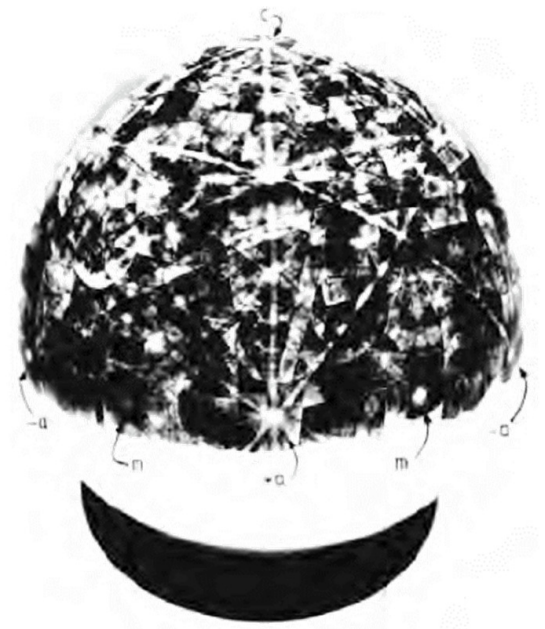

Figura 5 - Esfera de difração construída a partir de simulação numérica de padrões de difração EBSD (retirado de Schimdt \& Olesen, 1989). 


\section{REVISÃO CONCEITUAL}

\subsection{Mecanismos de deformação}

Os mecanismos de deformação garantem a manutenção da coesão entre os grãos, acomodando os problemas de espaço através de bandas de deformação, kinking, microfraturamento (baixas temperaturas), recristalização dinâmica ou deslizamento ao longo das bordas dos grãos (temperaturas mais altas).

O processo rúptil de microfraturamento resulta em descontinuidades planares nos grãos com dilatação e deslocamento, e podem se nuclear em pequenas falhas no retículo cristalino, em bordas de grãos e em inclusões fluidas ou sólidas.

Já o mecanismo de dissolução-precipitação ocorre em decorrência da presença de fluidos intergranulares, que facilitam o processo de dissolução no contato entre grãos quando existe uma alta tensão diferencial aplicada. Esse mecanismo ocorre preferencialmente em condições de metamorfismo de baixo grau devido à necessidade da presença de fluido intergranular. A dissolução ocorre perpendicularmente à direção de maior tensão aplicada e precipita em regiões de menor tensão (Passchier \& Trouw, 2005), como veios e sombras de deformação.

Os cristais geralmente contêm defeitos em sua estrutura cristalina, que podem ser causados tanto por vacâncias e intersticiais pontuais (point defects), como por defeitos lineares (linear defects) ou deslocações (dislocations) resultantes de planos extras de átomos no retículo. A deformação dúctil intracristalina é causada pela migração destes defeitos através do retículo do cristal, sendo uma deformação permanente.

A deformação por movimentação da linha de deslocamento (edge dislocation ou dislocation line) em planos e direções cristalográficas específicas (slip systems) é conhecida como deslizamento das deslocações (deslocation glide, Figura 6a). O tipo de sistema de deslizamento ativado dependerá do rompimento da tensão crítica cisalhante (Critical Resolved Shear Stress - CRSS), que varia com a composição 
química do mineral e condições de metamorfismo. A CRSS de cada sistema de deslizamento muda com a temperatura e a atividade química de certos componentes. Outra movimentação cristalina possível é a migração do plano de deslocamento definido pela linha de deslocamento (edge dislocation) para um plano superior ou inferior caracterizando salto do deslocamento (dislocation climb, Figura 6b). A movimentação pela combinação dos dois tipos de deslocamento (glide e climb), pela formação e destruição de deslocações é chamada de fluência de deslocações dislocation creep (Nicolas \& Poirier, 1976).

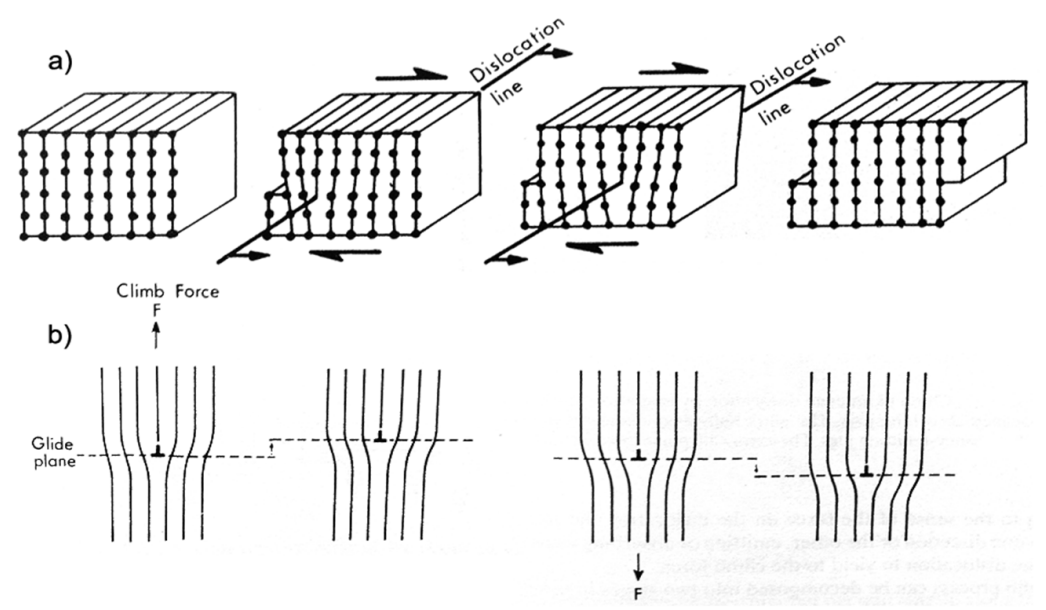

Figura 6 - a) Deslizamento de um cristal por propagação de uma borda de deslocamento (dislocation glide). b) Salto de um plano de deslizamento para um nível superior ou inferior (in: Nicolas \& Poirier, 1976).

Os processos geminação e kinking atuam junto aos os mecanismos de deformação intracristalinos e também resultam na mudança da forma dos cristais. A geminação mecânica ocorre em direções cristalográficas específicas e um plano de deslocações separa o cristal em duas regiões simétricas. Já o processo de kinking não é limitado a nenhuma direção ou plano cristalográfico específico e o limite entre as duas porções do cristal não representa um plano espelhado. Este processo, formase por uma rotação progressiva dos átomos em torno de um eixo paralelo à intersecção de um plano de deslizamento e um limite de uma banda kink (Passchier Trouw, 2005). 
O processo de recuperação (recovery) busca a redução da energia interna de um cristal através da concentração dos defeitos espalhados pelo retículo cristalino em bordas inclinadas (tilt boundaries) por meio de deslocações. Dessa forma, os cristais que forem separados por bordas inclinadas com pequena diferença angular $\left(<10^{\circ}\right)$ entre seus retículos, passam a ser denominados subgrãos (Figura 7).

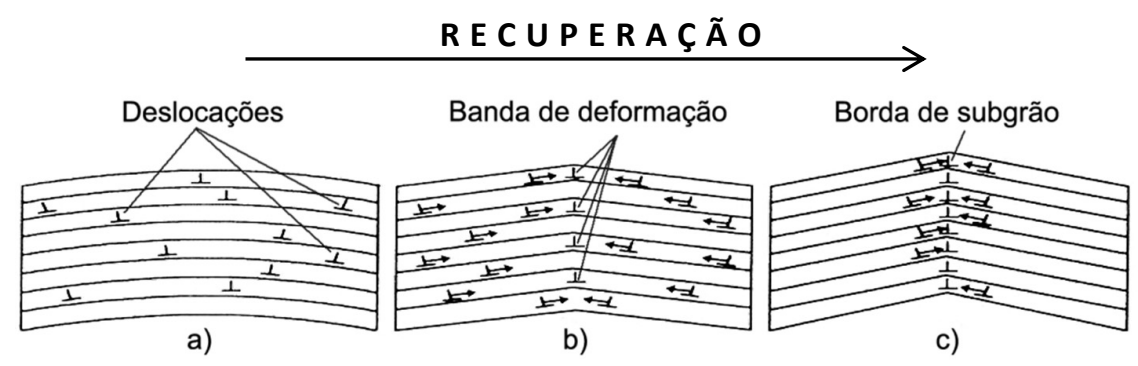

Figura 7 - a) A deformação intracristalina distribui deslocações com orientação sistemática pelo retículo cristalino que reflete visivelmente em extinção ondulante. b) Com a progressão da deformação mais deslocações se agrupam e formam uma banda de deformação. c) A diferença de orientação entre as duas partes se acentua e mais deslocações se concentram na banda de deformação, até que esta separa completamente as duas partes e se torna a borda de subgrão. Modificado de Blenkinsop (2000).

Assim como o processo de recuperação, o processo de recristalização também contribui na dissipação da energia livre diminuindo a densidade de deslocações. A recristalização que ocorre durante o processo deformacional é denominada recristalização dinâmica. Quando se é regida apenas pela influência térmica é chamada recristalização estática (annealing). Na recristalização dinâmica, o mecanismo dominante dependerá da temperatura e da taxa de deformação vigente podendo se dar por (a) migração lenta da borda (Bulging Recrystallization); por (b) rotação de subgrão (Subgrain Rotation Recrystallization); ou (c) migração rápida de borda de grão (Grain Boundary Migration). A recristalização por bulging (Figura 8a) resulta da migração da borda entre um cristal com menor densidade de deslocamentos para o interior de outro com maior densidade de maneira a formar um novo grão de granulação visivelmente mais fina. Esse processo atua nas porções de mais baixa temperatura do regime de fluxo de deslocações e em altas taxas de deformação no qual o salto de deslocações (deslocation climb) não consegue acompanhar a taxa de deformação imposta, aumentando a densidade de deslocações 
em alguns cristais. Esse mecanismo pode ocorrer em todo o entorno de um grão de alta densidade de deslocações podendo, por vezes, gerar texturas tipo manto-núcleo. A recristalização por rotação de subgrão (Figura $8 b$ ) resulta da desorientação progressiva de um subgrão e se torna importante com o aumento da temperatura ou diminuição da taxa de deformação. Acontece quando as deslocações movem livremente entre planos cristalográficos diferentes (climb) de forma suficiente a acomodar recuperação (recovery), aumentando o ângulo entre os retículos cristalinos em ambos os lados da borda do subgrão levando-o a sua rotação. Aumentando ainda mais a temperatura ou diminuindo a taxa de deformação, o mecanismo de migração de bordas (Figura 8c) impera sobre os dois mecanismos supracitados, eliminando assim as deslocações e as bordas de subgrãos, formando bordas lobadas. A recristalização estática ocorre pela diferença de energia livre entre os grãos deformados - que apresentem alta densidade de deslocações - e grãos livres de deslocações. Os últimos começam a crescer espontaneamente de maneira a reduzir a energia livre total da rocha, produzindo textura poligonal.

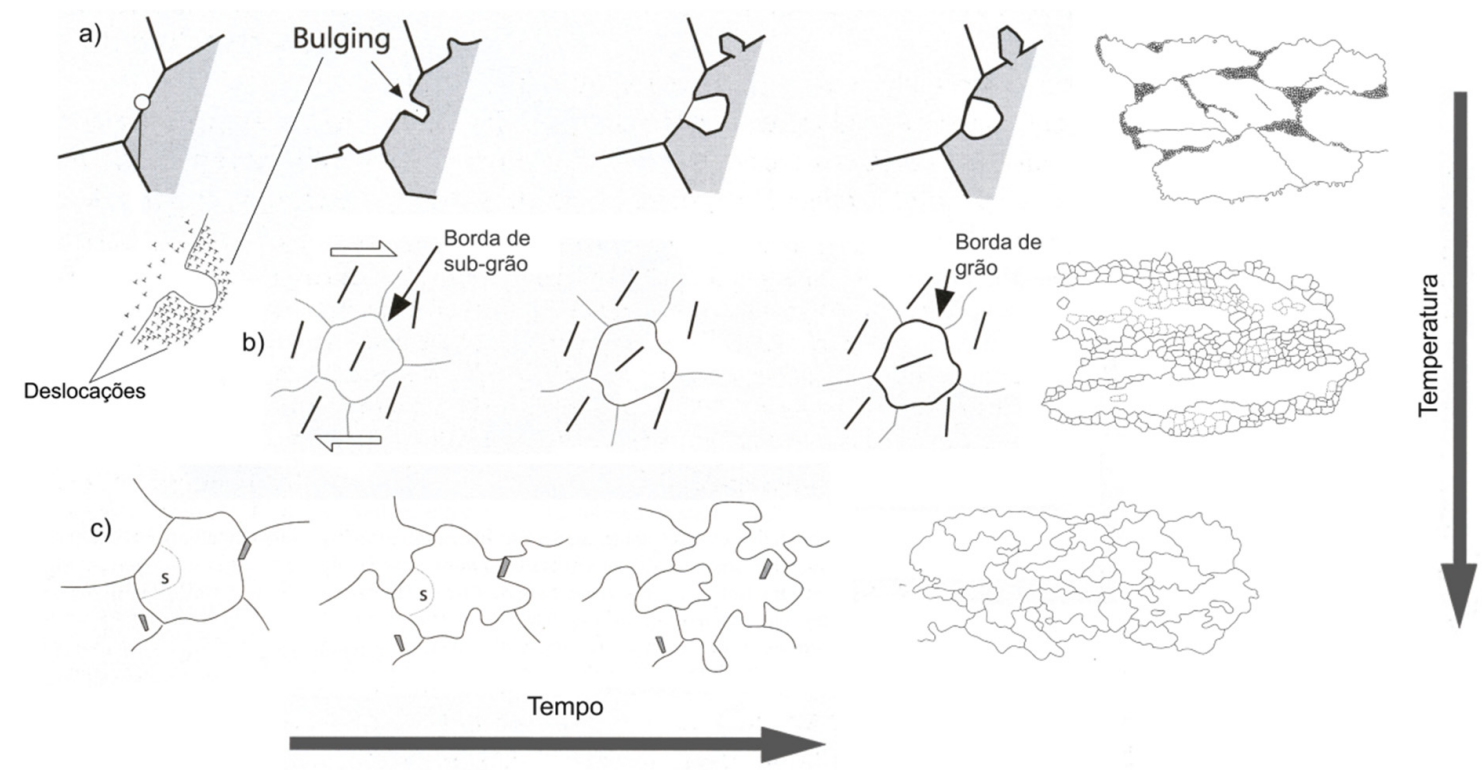

Figura 8 - a) Bulging, resultado da migração da borda de um grão dentro de outro grão com uma maior densidade de deslocações. b) Recristalização por rotação de subgrão. c) Recristalização por migração de borda de grão. Modificado de Passchier \& Trouw (2005) e Stipp et al. (2002). 
Quando uma rocha é deformada em alta temperatura, relativamente à de fusão dos seus minerais constituintes, seus grãos podem se deformar apenas por migração das vacâncias dentro do retículo cristalino. Esse processo é conhecido como fluência difusa em estado-sólido (solid-state diffusion creep - Passchier \& Trouw, 2005) e pode se dar pela difusão das vacâncias na rede cristalina ao longo das bordas dos grãos (fluência Coble - Coble creep) ou pela difusão das vacâncias através do retículo cristalino (fluência Nabarro-Herring - Nabarro-Herring creep).

Outro mecanismo que pode ocorrer em agregados de grãos finos é o deslizamento ao longo das bordas dos grãos (grain boundary sliding -Passchier \& Trouw, 2005) que consiste no deslizamento entre grãos durante o processo deformacional. O desenvolvimento de aberturas (que seriam poros na rocha) entre os cristais é impedido pelo auxílio dos mecanismos difusivos em estado sólido ou via dissolução e precipitação por um fluido de borda de grão. É um mecanismo importante por permitir a acomodação de grande quantidade de deformação em agregados de grãos finos $(1-10 \mu \mathrm{m})$ equidimensionais sem que se desenvolva uma trama bem marcada ou clara OPC. Na geologia, o mecanismo também é chamado de deformação super-plastica (superplastic deformation - e.g. Schmid, 1982).

\subsection{Orientação Preferencial Cristalográfica}

A trama de uma rocha inclui uma completa configuração espacial e geométrica de todos os seus elementos como textura, estrutura e OPC (Hobbs et al., 1976). Em muitas rochas deformadas constituídas por minerais de morfologia planar ou alongada em uma direção preferencial, é relativamente fácil reconhecer uma trama que se traduz como uma foliação ou lineação. No entanto, para rochas formadas essencialmente por minerais como quartzo ou calcita, por exemplo, o reconhecimento de uma orientação preferencial pode ser mais complicado.

De acordo com Schmid \& Casey (1986), o desenvolvimento da trama (fabric) depende essencialmente de fatores como (i) os mecanismos de deformação ativos, (ii) a forma do elipsoide de deformação finito, e (iii) a magnitude e caminho (path) da deformação (kinematic framework). Uma OPC pode ser definida como sendo um 
arranjo espacial sistemático dos retículos cristalinos dos grãos que compõem uma rocha, organizados por processos e mecanismos deformacionais. Diversos mecanismos podem promover uma OPC; entretanto, a fluência por deslocações (dislocation creep) parece ser o mecanismo preponderante (Passchier \& Trouw, 2005).

O desenvolvimento da OPC em uma rocha depende (Schmid, 1994): (i) dos sistemas de deslizamento operantes e do respectivo grau de atividade; (ii) do regime de deformação (plana, constricional ou achatamento), determinante para saber qual a direção de rotação os cristais e, portanto, a forma da trama; (iii) da deformação finita; (iv) do tipo de deformação, tendo em vista que a deformação progressiva não-coaxial gera padrões de OPC com simetria monoclínica, enquanto deformação progressiva coaxial gera padrões com simetria mais elevada; $(v)$ da atividade da recristalização dinâmica por BLG e GBM; (vi) do crescimento de grãos por solução, uma vez que a taxa de crescimento de grãos de muitos minerais dependem da direção cristalográfica, produzindo assim uma orientação preferencial.

Padrões de eixos-c representam apenas uma pequena parte dos indicadores da OPC de quartzo e o estudo da orientação de outras direções cristalográficas - como os eixos-<a> - também precisam ser conhecidas para permitir a correta interpretação do desenvolvimento da OPC.

Em condições metamórficas de baixo a médio grau, o tipo de fluência e a deformação finita controlam a geometria da OPC de quartzo acumulada no cisalhamento puro (Figura 9) 


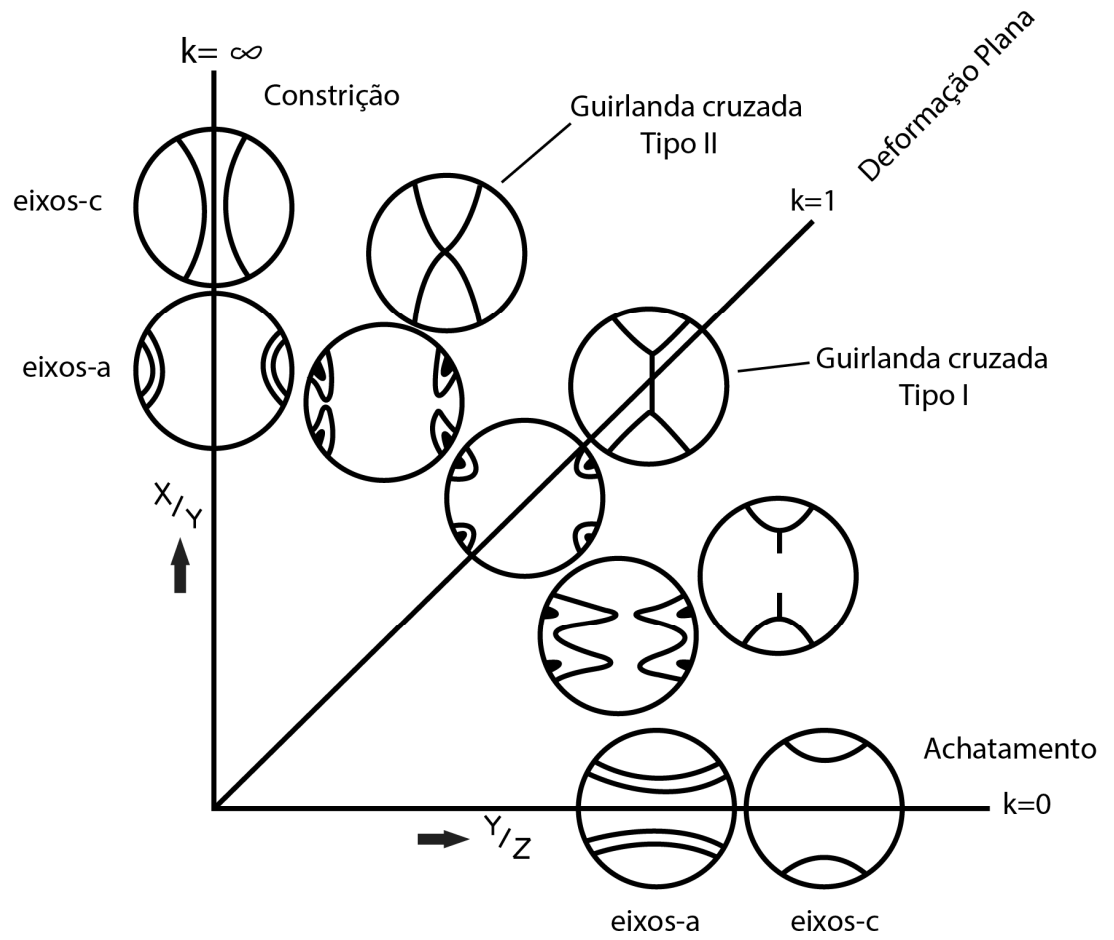

Figura 9 - Figuras de polo com padrões de OPC de eixos-c e eixos-<a> esperados em uma deformação coaxial dentro de diferentes áreas do diagrama de Flinn (modificado de Schmidt \& Casey, 1986).

Guirlandas de pequeno círculo em torno do eixo-Z de deformação são as mais comuns. Entretanto, na deformação plana, elas podem se conectar através de uma guirlanda central produzindo o padrão de guirlandas cruzadas Tipo-I. Outro tipo de guirlanda cruzada que se desenvolve sob deformação progressiva coaxial é a do TipoII, a qual parece se formar em constrição (Bouchez, 1978) com máxima densidade de eixos-c no entorno do eixo-Y de deformação. Ambos os padrões se formam em temperaturas mais altas que os padrões não conectados por uma guirlanda central. Com o aumento da temperatura, o ângulo dos pequenos círculos das guirlandas abrem progressivamente (Kruhl, 1998).

Padrões de eixos-c distintos se desenvolvem no caso de deformação plana não-coaxial progressiva (Figura 10). Os padrões mais comuns são guirlandas cruzadas do Tipo-I levemente assimétricas e guirlandas únicas levemente inclinadas em direção à foliação e lineação de estiramento. Em condições de médio a alto-grau, um máximo distinto ocorre em torno do eixo-Y de deformação, enquanto que em 
temperatura elevada, acima de $650{ }^{\circ} \mathrm{C}$, os máximos concentram-se em torno da lineação de estiramento (Mainprice et al., 1986).

Tais padrões de eixos-c podem ser explicados como efeito da ativação combinada dos planos de deslizamento dominantes no quartzo. Os sistemas principais que atuam em temperaturas abaixo de $650{ }^{\circ} \mathrm{C}$ são o basal $<a>$, rombo $<a+c>$ e prisma $<a>$. Em baixas temperaturas, a ativação do sistema basal <a $>$ é dominante e concentra eixos-c na periferia do diagrama. Por outro lado, em condições médias de temperatura, o sistema romboédrico $<a+c>$ é dominante e sua ativação contribui para a concentração de eixos-c entre o centro e bordas, enquanto em temperatura média a alta, o plano de deslizamento prisma<a> concentra eixos-c no centro do diagrama. Em consequência aos deslizamentos na direção de <a>, os eixos$<a>$ tendem a se aglomerar perto de planos e direções de máxima deformação infinitesimal de cisalhamento.

No achatamento, os eixos-<a> se aglomeram em pequenos círculos no entorno da direção de encurtamento (Figura 9). Em constrição, uma guirlanda de pequeno círculo se forma em torno da direção de extensão e, na deformação plana, eles formam duas direções distintas próximo ao eixo X. (Lister \& Hobbs 1980; Jessel \& Lister 1990; Passchier \& Trouw 2005 e Takeshita et al 1999).

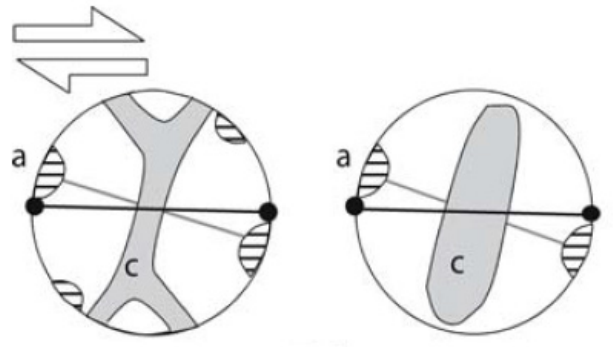

T baixa

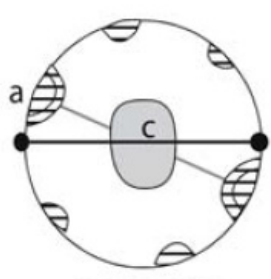

T média

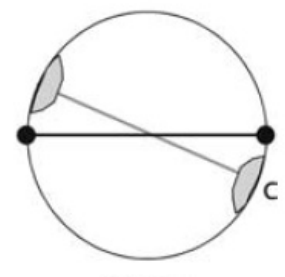

T alta

Figura 10 - Diagrama de polos mostrando o desenvolvimento de quatro tipos de contorno de padrões de OPC de eixos-c de quatzo (cinza) e eixos-a (listrado) com o aumento do grau metamórfico em deformação progressiva não-coaxial. A variação é causada pela mudança do sistema de escorregamento dominante (retirado de Paschier \& Trouw, 2005). 
É possível determinar a temperatura deformacional de tectonitos ricos em quartzo utilizando dados de trama cristalográfica. Alguns termômetros empregados são: (i) o ângulo de abertura (Opening-Angle) em tramas de eixos-c de quartzo, que permite estimar a temperatura quando o processo dominante de recristalização dinâmica é a fluência por deslocações; (ii) a análise das microestruturas de recristalização presentes, baseada nos processos de recristalização dinâmica característicos de determinadas condições metamórficas.

O primeiro método, proposto por Kruhl (1998), relaciona ângulos de abertura de trama de eixos-c de quartzo com a temperatura deformacional. A relação foi desenvolvida a partir da compilação de conjuntos de dados com temperaturas previamente definidas através de termômetros petrológicos (i.e. assembleia mineral). Posteriormente, Morgan \& Law (2004) acrescentaram novos dados e propuseram uma relação linear entre as grandezas baseada em uma maior densidade de dados. Essa relação permite estimar a temperatura de deformação a partir do ângulo de abertura da trama com uma incerteza de $\pm 50^{\circ} \mathrm{C}$ (Figura 11). A incerteza está associada com a sensibilidade do método à taxa de deformação e ao enfraquecimento hidrolítico.

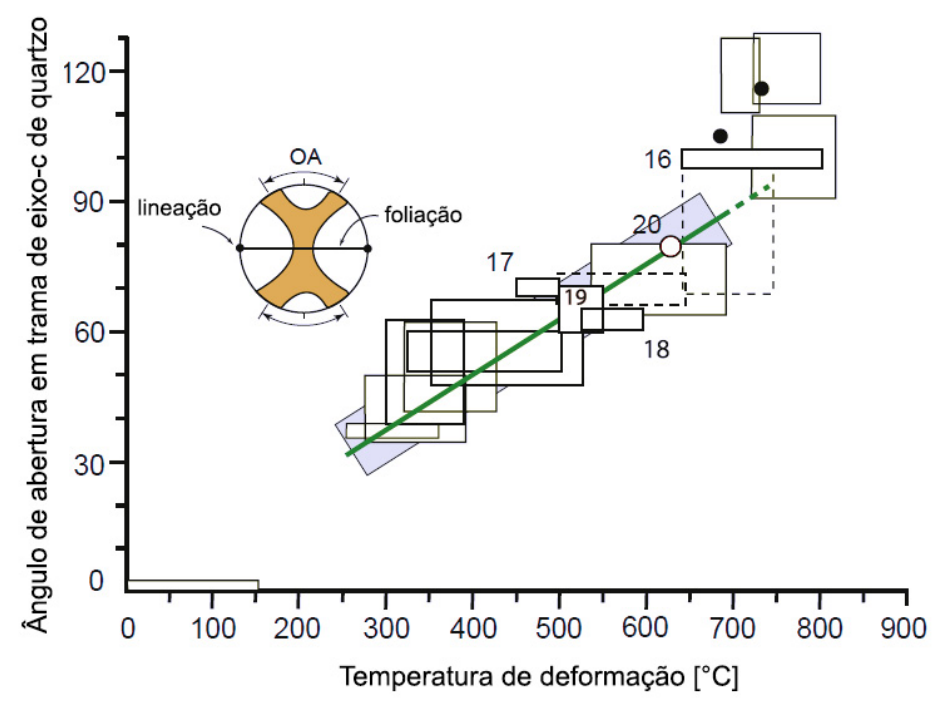

Figura 11 - Gráfico com dados de ângulo de abertura de trama de eixos-c de quartzo de vs. temperatura de deformação de rochas naturalmente deformadas de diversas localidades (para localização, ver Morgan \& Law, 2004). A reta verde (estimada através de interpolação visual) permite estimar a temperatura deformacional dentro da faixa entre 300-650 ${ }^{\circ} \mathrm{C}$. A faixa cinza (por trás do conjunto de dados) representa a incerteza (Modificado de Law, 2014). 
O termômetro baseado em microestruturas de recristalização em quartzo é abalizado nos estudos de Stipp et al. (2002), nos quais foram amostrados veios de quartzo recristalizado em rochas sedimentares metamorfizadas por contato ao longo do pluton Adamello, nos Alpes italianos. De dentro para fora da parede do pluton, três mecanismos de recristalização foram indicados por microestruturas de recristalização (Figura 8) nos veios e associados a temperaturas de assembleias minerais sincinemáticas: GBM (grain boundary bulging recrystallization) em temperaturas mais baixas afastadas do pluton, SGR (subgrain rotation recrystallization) em temperaturas intermediárias da aureola e GBM (grain boudary migration recrystallization) em temperaturas altas. Essas microestruturas de recristalização (Figura 12) poderiam então servir para derivar, ao menos aproximadamente, a temperatura de deformação em milonitos sem assembleias minerais sin-tectônicas disponíveis. Vale ressaltar que o método também é sensível à taxa de deformação e ao enfraquecimento hidrolítico.

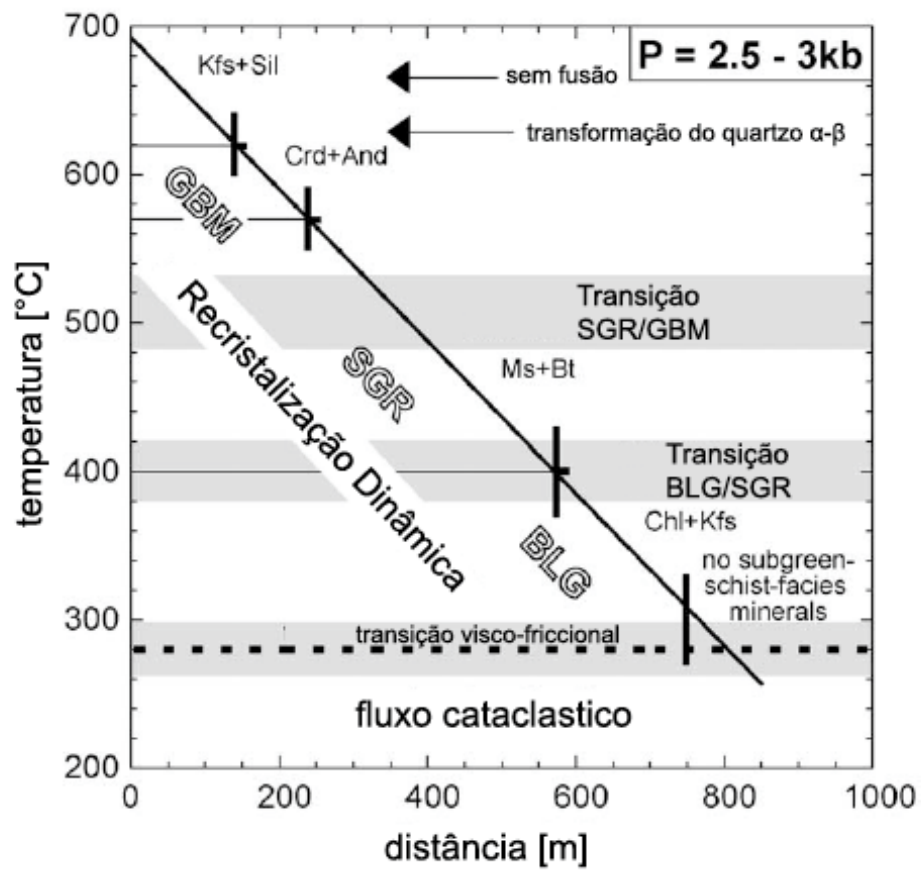

Figura 12 - Gráfico de relação entre a temperatura (processos de recristalização) e distância ao longo do perfil em Tonale. As barras pretas verticais são os erros de estimação das isógradas de reação (retirado de Stipp et al., 2002). 


\section{GEOLOGIA REGIONAL E CONTEXTO GEOLÓGICO ESTRUTURAL DA ÁREA EM ESTUDO}

A Província Borborema compreende a região nordeste da Plataforma SulAmericana arquitetada por orógenos neoproterozoicos separando principalmente sequências paleoproterozoicos e eventualmente núcleos arqueanos (Almeida et al., 1977). A província é limitada ao sul pelo Craton São Francisco e, a oeste, pela Bacia do Parnaíba (Figura 13). Numa reconstrução pré-deriva mesozoica, a Borborema faz parte de uma extensa cadeia orogenética com continuidade na África Ocidental ao longo dos escudos do Benin-Nigéria e Hoggar.

A deformação de continentes submetidos à colisão é frequentemente acomodada por zonas de cisalhamento de escala continental (Tapponnier \& Molnar, 1976). Essas zonas de elevada taxa de deformação geralmente são caracterizadas por corredores de rochas miloníticas reconhecidos em imagens de satélite como "lineamentos". A colagem Brasiliana no NE brasileiro, resultante da colisão dos crátons São Francisco e Oeste Africano, produziu um sistema interconectado de zonas de falhamentos transcorrentes, sendo as mais conhecidas a de Senador Pompeu, Patos e Pernambuco (Figura 13). A complexidade desse arcabouço tectônico tem sido atribuída à aglutinação de terrenos alóctones (e.g. Jardim de Sá et al., 1992; Jardim de Sá, 1994; Santos, 1996), com destaque para o lineamento Patos que separa domínios crustais com histórias geológicas distintas a norte e a sul da estrutura. 


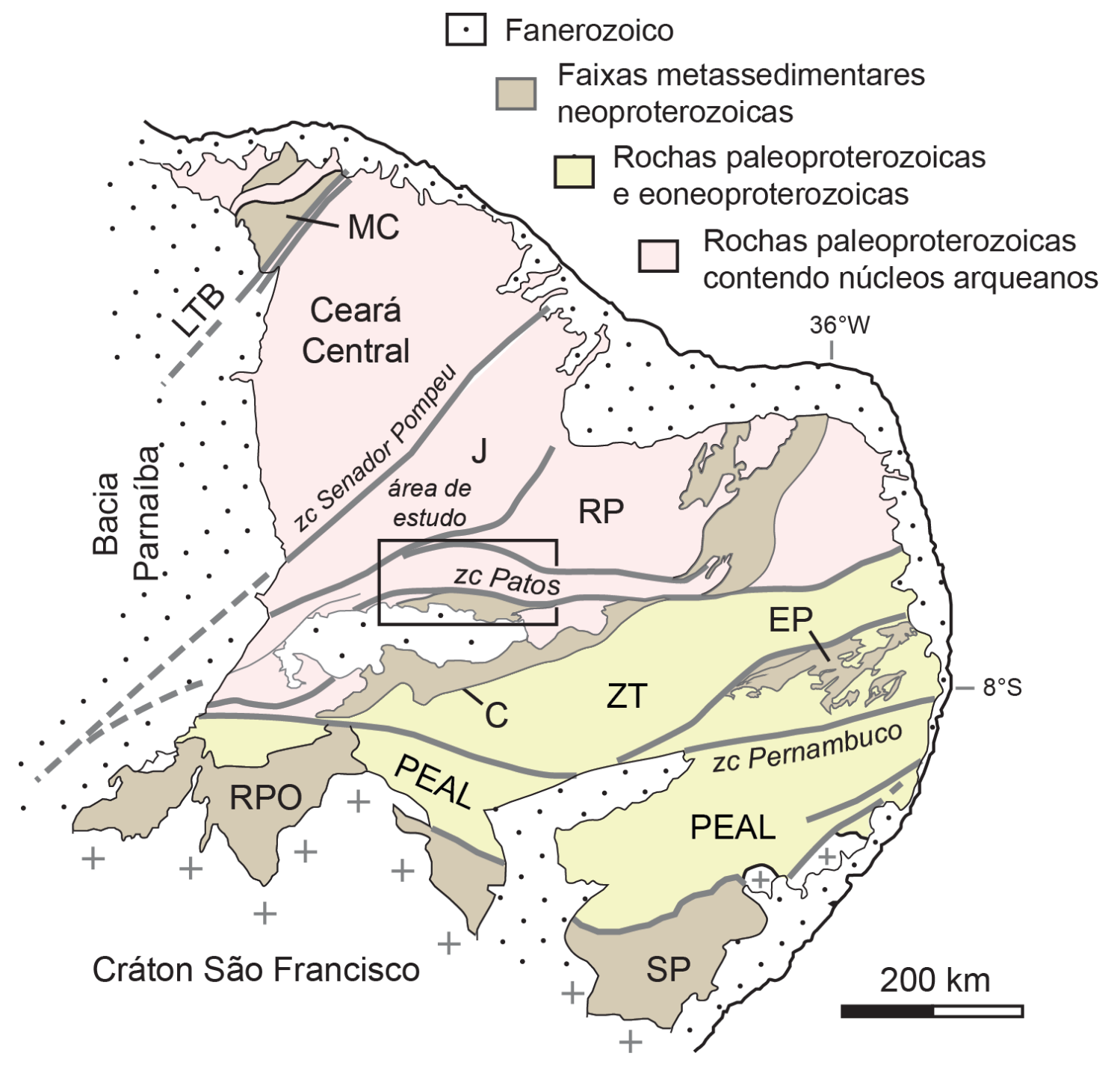

Figura 13 - Compartimentação tectônica da Província Borborema realçando blocos crustais limitados pelas zonas de cisalhamentos e bacias metassedimentares. O destaque retângulo localiza o Bloco Assaré, foco deste trabalho. (LTB, Lineamento Trans-Brasiliano; MC, Médio Coreaú; J, Bloco Jaguaribe; $R P$, Rio Piranhas; SE, Seridó; C, Cachoeirinha; EP, Leste Pernambuco; SP, Sergipano; RPO, Riacho do Pontal; ZT, Zona Transversal e PEAL, domínio Pernambuco-Alagoas). Modificado de Van Schmus et. al.(2008).

As rochas precambrianas situadas a norte do lineamento Patos, em especial no estado do Ceará, tem sido subdivididas em domínios (ou blocos) crustais cujos limites correspondem aproximadamente ao traço das grandes zonas de cisalhamento. No NW do Ceará, o domínio Médio Coreaú é limitado pela falha de Café-Ipueiras (segmento nordeste do lineamento Transbrasiliano). Nele ocorrem metaplutônicas 
siderianas (c. 2,35 Ga) e rochas metassedimentares neoproterozoicas (Santos et al., 2008; Ganade de Araújo et al., 2012). O domínio "Ceará Central" está situado entre a falha de Café-Ipueiras e a zona de cisalhamento de Senador Pompeu, enquanto os domínios Jaguaribeano e Rio Piranhas estão situados a leste da Senador Pompeu. O Ceará Central é caracterizado por metaplutônicas riacianas (c. 2,2 Ga) contendo núcleos arqueanos (unidade Pedra Branca), e sequências metassedimentares clásticas depositadas no neoproterozoico (Ganade de Araújo et al., 2012). Uma feição distintiva do Ceará Central é a presença do arco magmático neoproterozoico de Santa Quitéria, que inclui lentes de rochas de alta pressão formadas em zonas de subducção (Amaral et al., 2012). O domínio Jaguaribeano e Rio Piranhas, por sua vez, incluem faixas vulcano-sedimentares e metaplutônicas orosirianas (c. 1,75 Ga) encaixas em sequências do embasamento riaciano (Sá et al., 1995; Hollanda et al., 2011). O Jaguaribeano é limitado a sul pelas zonas de cisalhamento Tatajuba-Patos-Malta, que por sua vez define a borda setentrional do Bloco Assaré (Fetter, 1999).

\subsection{A zona de cisalhamento Patos}

O Lineamento Patos forma uma faixa contínua de milonitos de direção NE-SW a E-W que se estende por mais de 400 km ao longo dos estados da Paraíba e Ceará (Vauchez et al., 1995). A estrutura é visível em imagens de satélite e claramente detectada em mapas aeromagnéticos e gravimétricos (Oliveira, 2008). Ela deforma e metamorfiza em alto grau rochas de domínios geológicos distintos, como o Rio Piranhas-Seridó a norte e Piancó-Alto Brígida/Alto Mochotó a sul. Na sua porção central ele justapõe unidades do embasamento Paleoproterozoico e suas coberturas depositadas no Neoproterozoico, correspondendo às faixas Seridó e Cachoeirinha.

O lineamento é definido pela presença de rochas miloníticas comumente verticais com penetrativa lineação de estiramento mineral sub-horizontal. Na sua porção oriental os milonitos separam gnaisses e migmatitos de idade paleoproterozoica a norte, de sequências eoneoproterozoicas a sul. A milonitização ocorreu na condição de alta temperatura em meio a mobilizados sin-cinemáticos (Nascimento \& Galindo, 2010). No setor central, a zona de cisalhamento Patos converge para um cinturão metassedimentar de direção NE (Faixa Seridó), cuja 
deformação é caracterizada por foliações em leque associada ao estiramento dúctil de direção NNE (Corsini et al., 1991). No setor ocidental, o lineamento conecta-se à zona de cisalhamento Tatajuba de direção NE-SW. A área em estudo situa-se justamente na junção desses cisalhamentos (Figura 13), também conhecido como Bloco Assaré (Fetter, 1999).

Dados geocronológicos e estruturais recentes do setor central do Patos mostraram que a migmatização sin-cinemática foi um evento relativamente tardio na província. Nesse setor a zona de cisalhamento é formada por um domínio deformado em alta temperatura, chegando a migmatização e, ao longo da borda sul da estrutura, um domínio retrometamórfico na fácies xisto-verde. O estudo geocronológico (U-Pb, SHRIMP) do setor migmatizado mostrou núcleos de zircão com idade paleoproterozoica, em torno de $2.2 \mathrm{Ga}$, o que foi atribuído a uma idade herdada de zircões das rochas regionais parcialmente fundidas e recristalizadas durante a deformação cisalhante (Archanjo et al., 2013; Viegas et al., 2014). Por outro lado, as bordas recristalizadas desses grãos apresentaram idades entre 560 e $570 \mathrm{Ma}$, o que foi atribuído ao evento de alta temperatura que fundiu as rochas paleoproterozoicas.

As microestuturas dos tectonitos do setor migmatizado e da transição para os milonitos de baixa temperatura do setor central do Patos é marcado por uma progressiva redução do tamanho dos grãos acompanhada por recristalização. As tramas de quartzo e plagioclásio indicam que os sistemas cristalográficos foram ativados em alta temperatura através de deslizamento intracristalino associado à fluxo granular em meio parcialmente fundido (Viegas et al., 2013, 2014). A deformação na fácies xisto-verde da margem sul da estrutura foi marcada pela atividade do sistema de deslizamento basal do quartzo, em coerência com as condições de deformação sob temperatura mais baixa (Viegas et al., 2014). 


\subsection{O Bloco Assaré}

As unidades rochosas imbricadas limitadas pelo Lineamento Patos e a zona de cisalhamento Tatajuba compreendem sequências metapelíticas neoproterozoicas repousando sobre um embasamento que compreende ortognaisses e migmatitos paleoproterozoicos do Complexo Caicó (Medeiros 2008) e que inclui ainda uma unidade arqueana denominada "Complexo Granjeiro" (Silva et al., 1997).

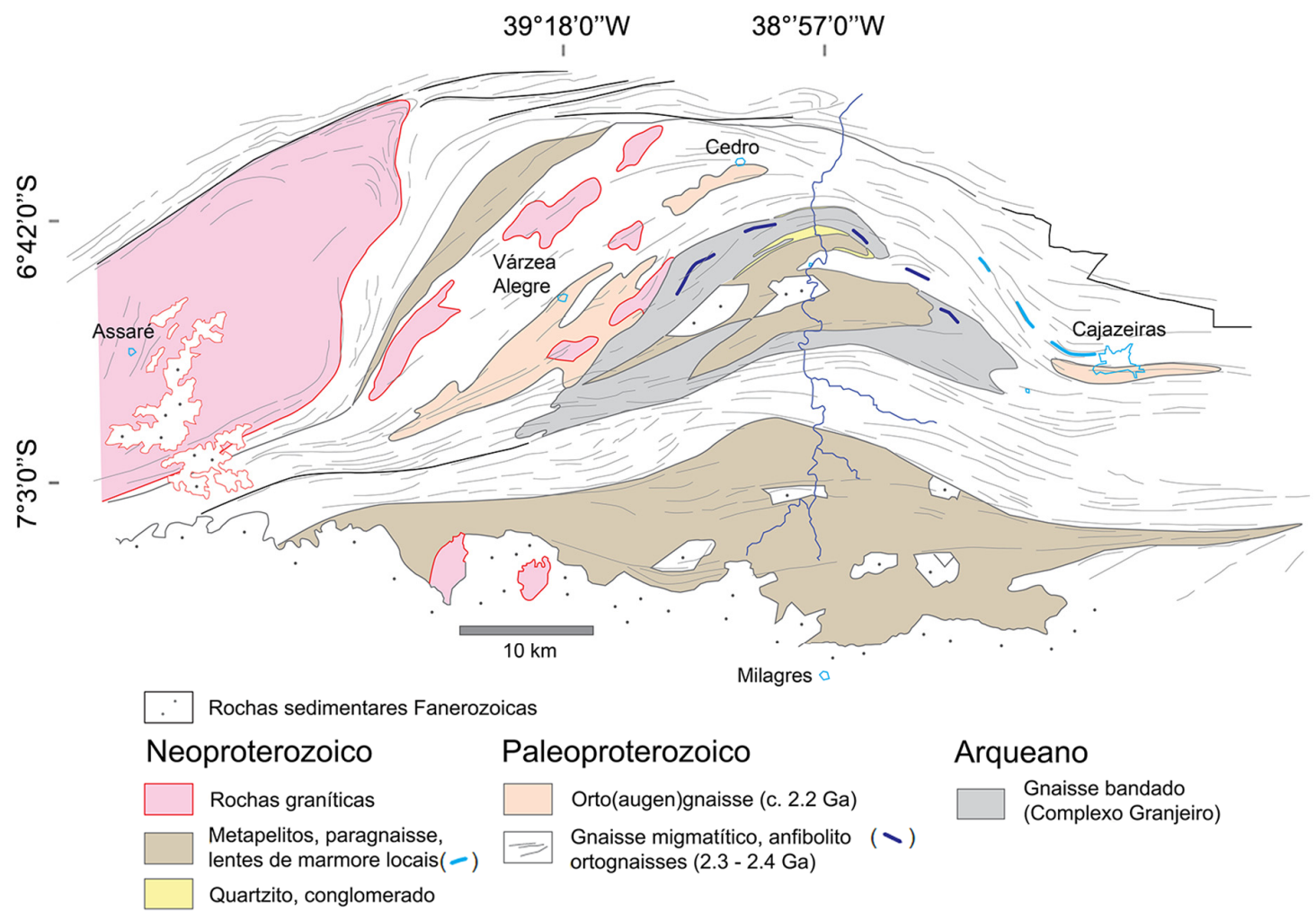

Figura 14 - Geologia do Bloco Assaré arquitetada por lascas imbricadas de gnaisses arqueanos e paleoproterozoicos, rochas graníticas e metassedimentares brasilianas e, por fim, coberturas sedimentares fanerozoicas (modificado do Mapa Geológico do Estado do Ceará; Cavalcante et al., 2003).

A sequência metassedimentar consiste na base de (meta)arenitos localmente conglomeráticos passando, em direção ao topo, para (meta)turbiditos (Figura 14). O grau metamórfico varia de xisto-verde com granada e biotita, a anfibolito com andaluzita e sillimanita notadamente próximo ao contato com o embasamento. Essa sequência metassedimentar repousa discordantemente sobre o Complexo Granjeiro (Figura 14), constituído por ortognaisses máficos-intermediários, metavulcânicas 
máficas, anfibolitos e gnaisses bandados finos, contendo intercalações de metaultramáficas, formações ferríferas, mármores e calciosilicáticas. Os litotipos máficos e ultramáficos normalmente encontram-se bastante intemperizados, sendo que nos termos mais preservados é possível caracterizar: i) anfibolitos com plagioclásio e clinopiroxênio, (ii) metagabros com clino- e ortopiroxênio e, iii) horblenditos/actinolititos com textura nematoblástica e granulação fina a média.

O metamorfismo no Complexo Granjeiro é compatível com condições de baixa pressão e temperatura moderada a alta, mas que pode inclusive chegar a fusão parcial e formação de migmatitos. A idade do complexo é presentemente indefinido, embora haja uma indicação para uma idade neoarqueana obtida em ortognaisse bandado próximo a cidade de Granjeiro (Silva et al., 1997). Datações ${ }^{40} \mathrm{Ar} /{ }^{39} \mathrm{Ar}$ em minerais extraídos de um metapelito (biotita), ortognaisse (muscovita) e anfibolito (hornblenda) forneceram idades platô que variaram de 524 a 549 Ma, e que foram atribuídas a exumação e resfriamento das rochas regionais (Monié et al., 1997).

Envolvendo o Complexo Granjeiro ocorrem sequências referenciadas ao Complexo Caicó (Medeiros, 2008). Os litotipos são representadas por termos metavulcanossedimentares e metaplutônicos comumente milonitizados e/ou migmatizados. O primeiro engloba biotita gnaisses por vezes com anfibólio, gnaisses bandados e metavulcânicas migmatizadas, com intercalações de mármores, anfibolitos, calcissilicáticas, metaultramáficas e mais raramente quartzitos. Os termos metaplutônicos correspondem a ortognaisses graníticos, granodioróticos e tonalíticos acinzentados, além de leucortognaisses e migmatitos, com porções variadas de biotita e anfibólio, geralmente apresentando textura granoblástica media a grossa ou porfiroclástica com augens de K-feldspato.

Determinações geocronológicas mais precisas do Complexo Caicó (métodos $\mathrm{Pb}-\mathrm{Pb}$ e U-Pb em zircão) são referidas na bibliografia em ortognaisses das regiões de Açu, São Vicente, Florânia e Caicó (RN). Nestes foram obtidas idades de 2170 Ma a 2246 Ma (Hackspacher et al., 1990; Legrand et al., 1991; Macedo et al., 1991; Dantas, 1992 e Van Schmus et al., 1995) definindo uma idade riaciana para este magmatismo.

O arcabouço estrutural do duplex foi definido por Corsini et al. (1996; Figura 15). O mergulho da foliação, vertical no Lineamento Patos, torna-se progressivamente menor para norte caracterizando a assimetria do sistema. A geometria da estrutura 
sugere que a trama planar converge em profundidade para uma única zona de cisalhamento e, como um todo, define uma estrutura em flor positiva assimétrica (Corsini et al., 1996). As escamas imbricadas contém uma persistente lineação de estiramento mineral sub-horizontal marcada por agregados de quartzo, feldspatos alongados e sombras de pressão em granadas sin-cinemáticas (Corsini et al., 1996). Indicadores cinemáticos nas zonas verticais que limitam as escamas imbricadas mostram um movimento destral independentemente da direção NE ou E-W das transcorrências. No contato entre as escamas, contudo, não há registro da cinemática envolvida, embora Corsini et al. (1996) postulem que o movimento nas lentes imbricadas teria sido convergente.

As demais unidades que compõe duplex também exibem estruturas penetrativas caracterizadas por uma trama planar sub-horizontal a inclinada que harmoniza em perfeita continuidade com o arranjo das zonas transcorrentes. Nessas estruturas, tanto as camadas quanto a foliação foram assimetricamente dobradas com vergência para norte, com o eixo das dobras paralelo a uma lineação de estiramento mineral presente em todos os litotipos da região. 


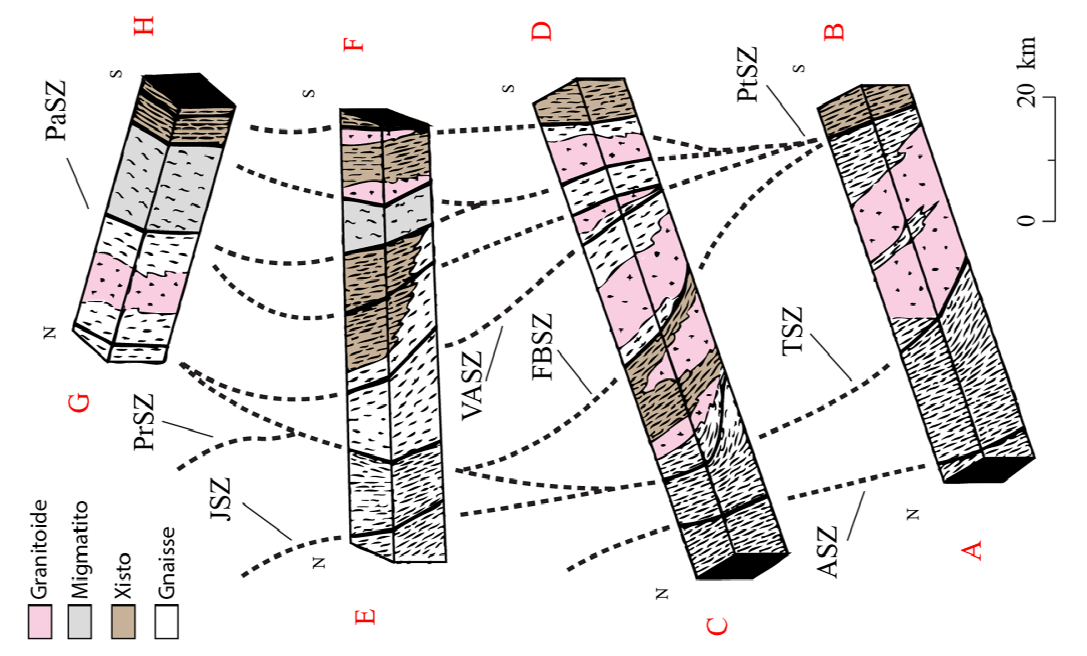

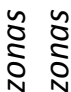

पर $\frac{4}{5}$

ज宛

$5 y$

उें

몽

을

त्ञ

这

ปे के

\&

1
5
0

1
0
0
0

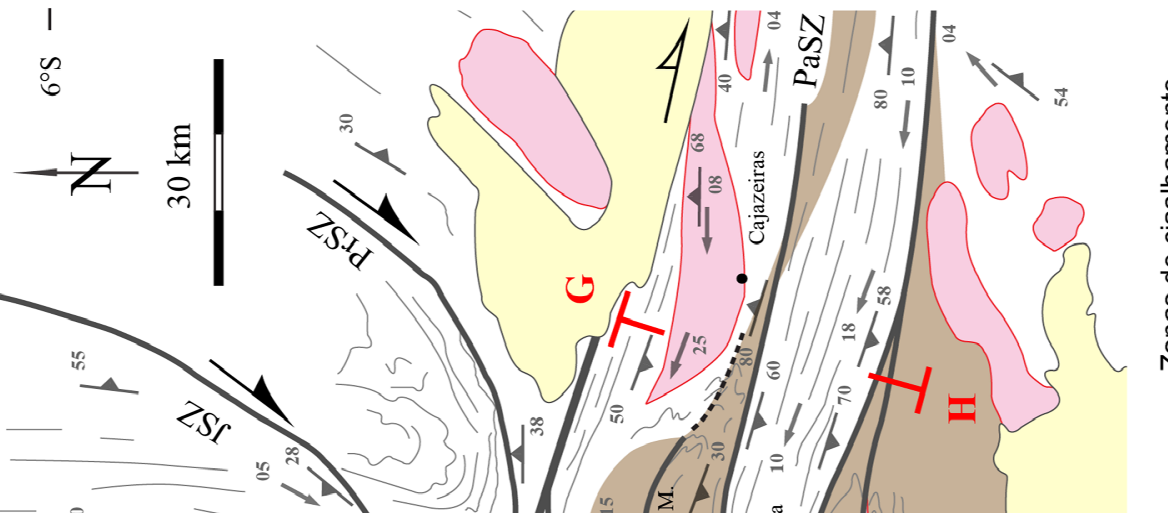

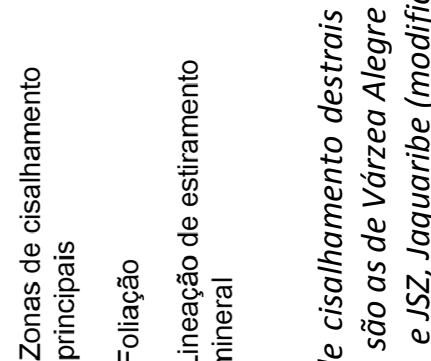

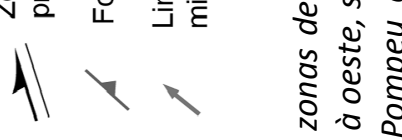

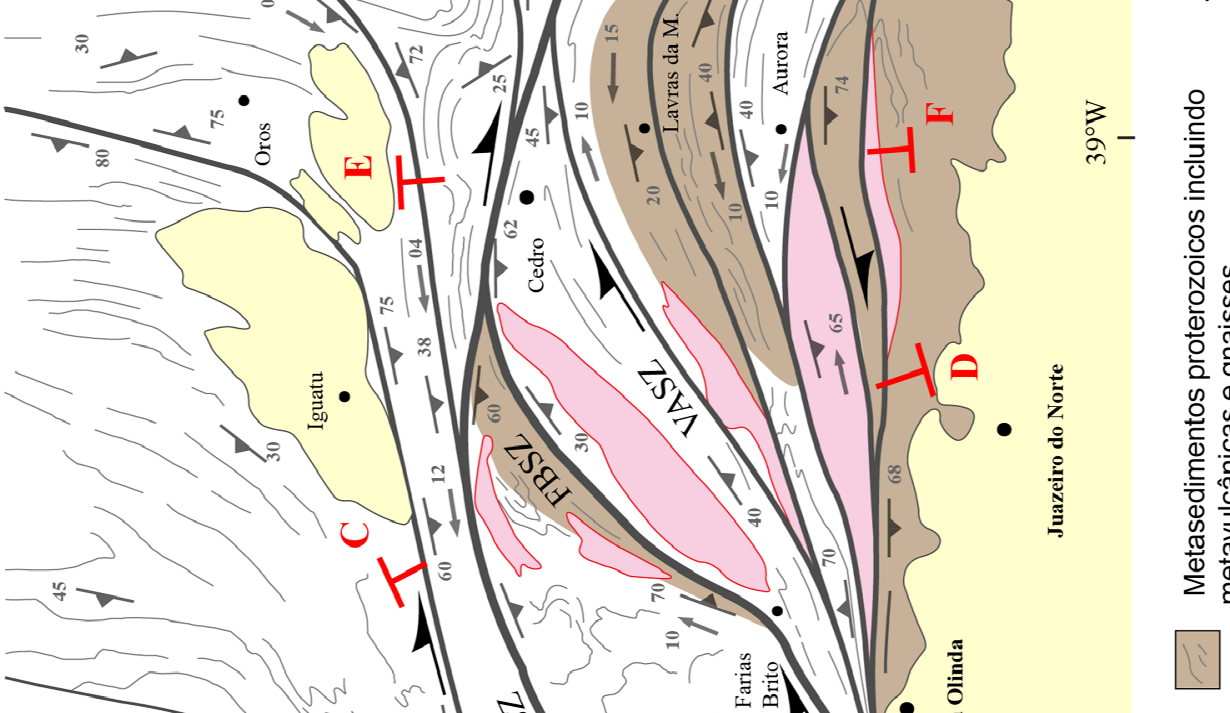

ปั

i⿱ 口)

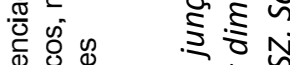

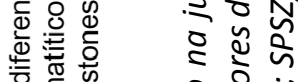

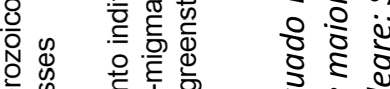

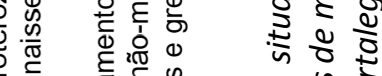

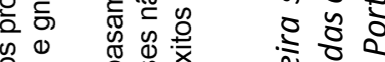

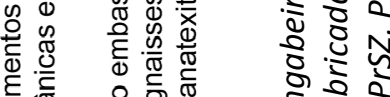

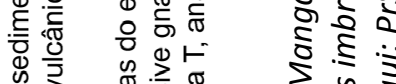

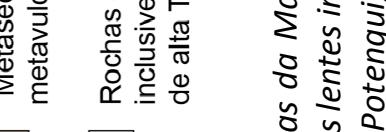

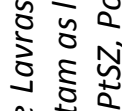

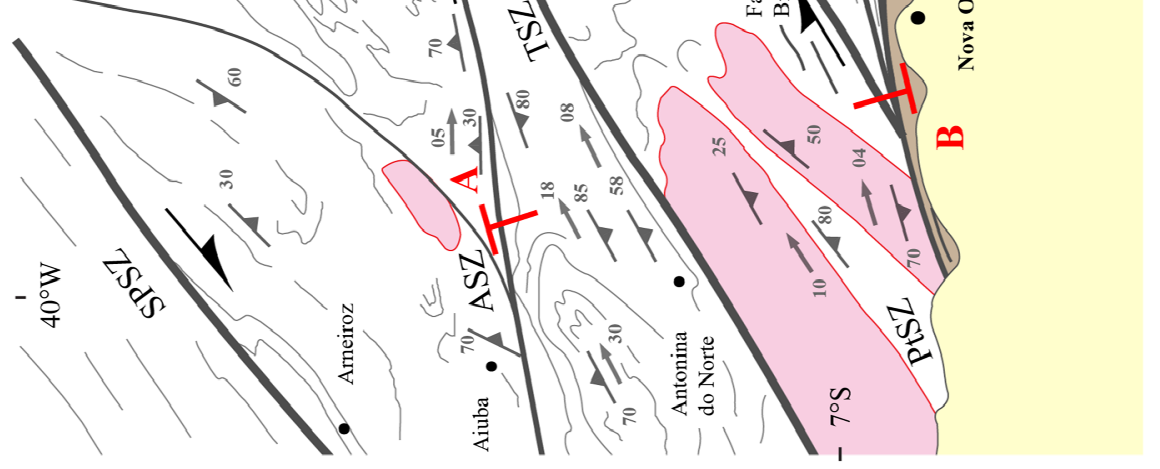

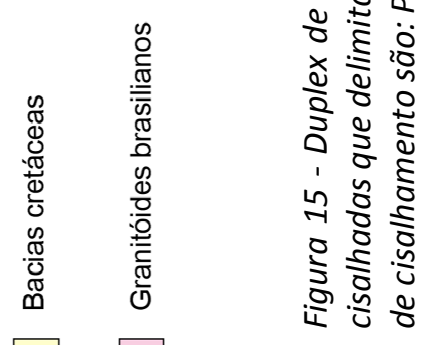




\section{GEOCRONOLOGIA}

\subsection{Apresentação}

Foram analisadas um total de seis amostras (Figura 16) sendo que três estão situadas no Complexo Granjeiro (LM2, LM 3 e LM10), e outras três (LM1, 11 e 13) em uma unidade indivisa $(\mathrm{A} \gamma)$ que, de acordo com o Mapa Geológico do Estado do Ceará (Cavalcante et al., 2003), teria idade arqueana. Os resultados das análises U-Pb em zircão estão listados nas tabelas do anexo A.

- Rochas fanerozoicas sedimentares

\section{Neoproterozoico}

Rochas graníticas

Metapelitos, paragnaisses e lentes de marmore ( $C)$

Quartzito, conglomerado

\section{Paleoproterozoico}

$\square$ Orto(augen) gnaisse (c. $2.2 \mathrm{Ga}$ )

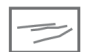
Gnaisse migmatítico, anfibolito ( ) ortognaisse (2.30 - $2.4 \mathrm{Ga})$

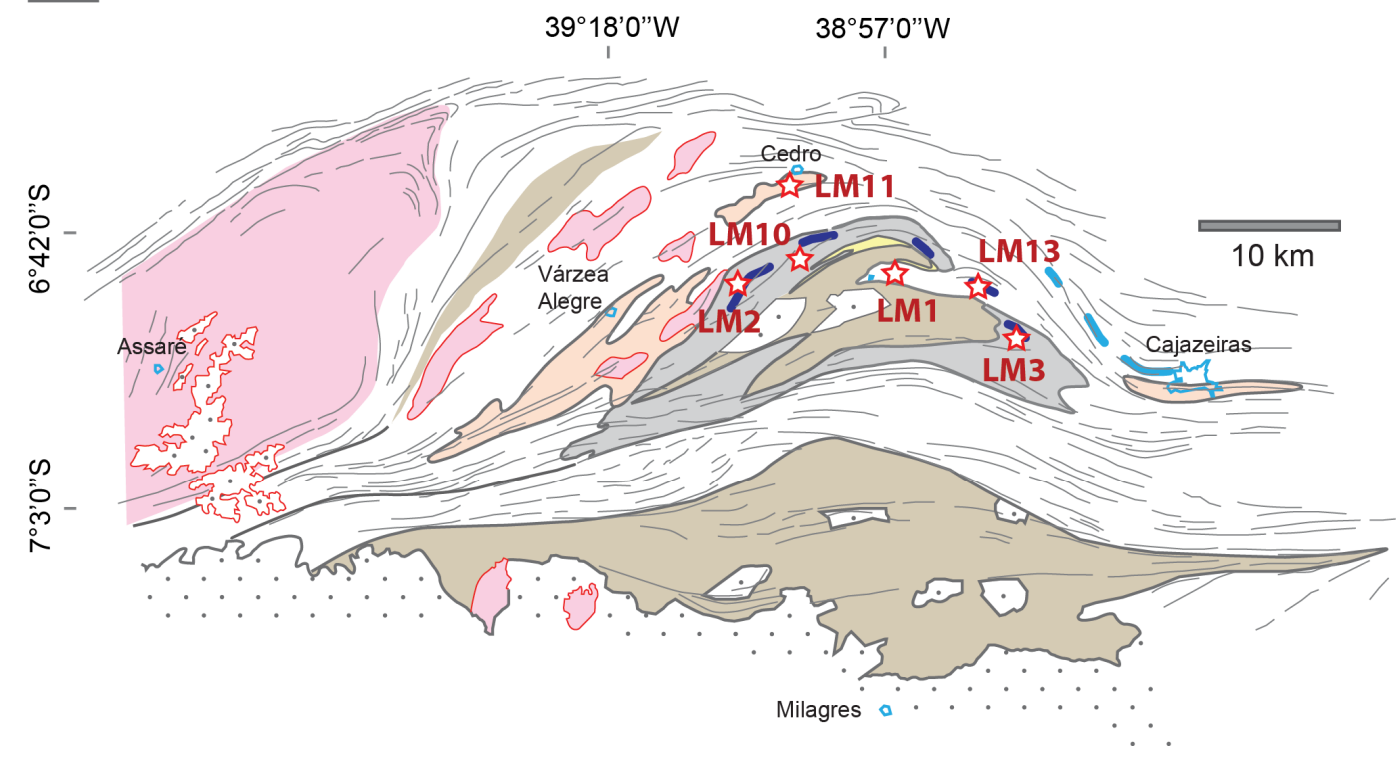

Figura 16 - Mapa geológico do bloco Assaré (modificado do Mapa Geológico do Estado do Ceará; Cavalcante et al., 2003) e localização das amostras para análises U-Pb em zircão. 


\subsection{Complexo Granjeiro}

Três amostras foram analisadas, sendo uma proveniente de um ortognaisse migmatítico (LM10), outra de uma metaultramáfica (LM2) e uma terceira de um gnaisse bandado (LM3). A amostra LM10 foi coletada em corte da estrada de ferro situado entre as cidades de Lavras da Mangabeira e Cedro. A rocha possui um aspecto venulado onde bandas mais claras de orientação regular estão encaixadas num gnaisse cinza de aspecto homogêneo (Figura 17). A amostra foi extraída do gnaisse cinza evitando-se, na medida do possível, os veios quartzo-feldspáticos mais claros. A ultramáfica (LM2) foi coletada no distrito de Mangabeira situado a leste da cidade de Várzea Alegre (CE). A amostra LM3 é proveniente de um corte de estrada na BR-116 próxima a localidade de Felizardo. Trata-se de um gnaisse com bandamento fino caracterizado pela alternância de faixas claras quartzo-feldspáticas, e cinza-escura mais rica em minerais máficos. A amostra foi extraída de uma banda cinza homogênea de aproximadamente 1 metro de espessura.

Amostra LM10 (UTM 500.123 / 9.259.584 SAD69 Z24S)

Trata-se de um ortognaisse de aspecto maciço contendo veios leucocráticos de composição granítica (Figura 17). Os veios, geralmente paralelos entre si e de espessura decimétrica a centimétrica, estão possivelmente relacionados a um evento de migmatização do ortognaisse. A rocha possui textura granolepidoblástica, com mineralogia formada essencialmente por matriz arranjada por grãos de quartzo (50\%), microclina (15\%) e plagioclásio (10\%) com granulação aproximada de $200 \mu \mathrm{m}$ e zircão e apatita (<1\%) como acessórios. Palhetas de muscovita (10\%) são maiores que as de biotita (15\%) e definem uma foliação incipiente. Os grãos de quartzo apresentam bordas levemente lobadas, sendo que alguns grãos se encontram bastante recristalizados e apresentam diâmetro de aproximadamente $1 \mathrm{~mm}$. Os grãos de quartzo apresentam também extinção ondulante, bem como bordas de subgrãos. 


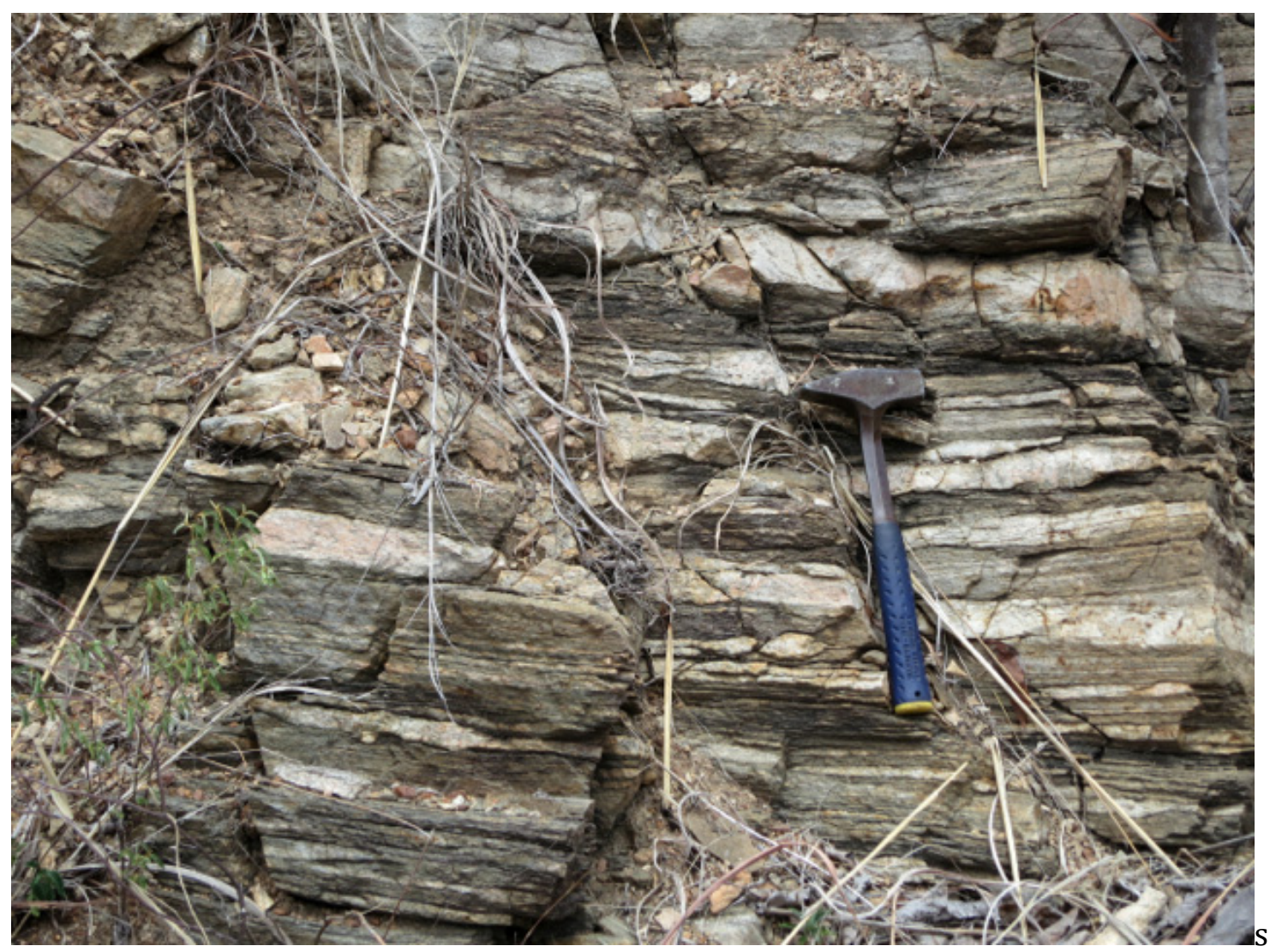

Figura 17 - Gnaisse bandado do Complexo Granjeiro (LM10, Fazenda Arrojado).

Os zircões apresentam tamanho variando entre 340 e $170 \mu \mathrm{m}$ e razão axial (comprimento:largura, a:c) entre 1,5:1 e 4:1. Os grãos são euédricos, pouco a moderadamente fraturados exibindo zoneamento oscilatório bem definido (Figura 18). Alguns zircões apresentam núcleos de aspecto metamitizado, ou caracterizado pelo padrão truncado do zoneamento oscilatório mais antigo por um mais novo. Contudo, a análise de diferentes setores no mesmo grão com zoneamento aparentemente distinto, ou de grãos com diferentes graus de luminescência, produziu idades semelhantes (Figura 18). Não há portanto evidência nesses grãos de superimposição de um novo evento térmico, com a idade mais nova encontrada (2440 Ma) atribuída a perda episódica de $\mathrm{Pb}$. 

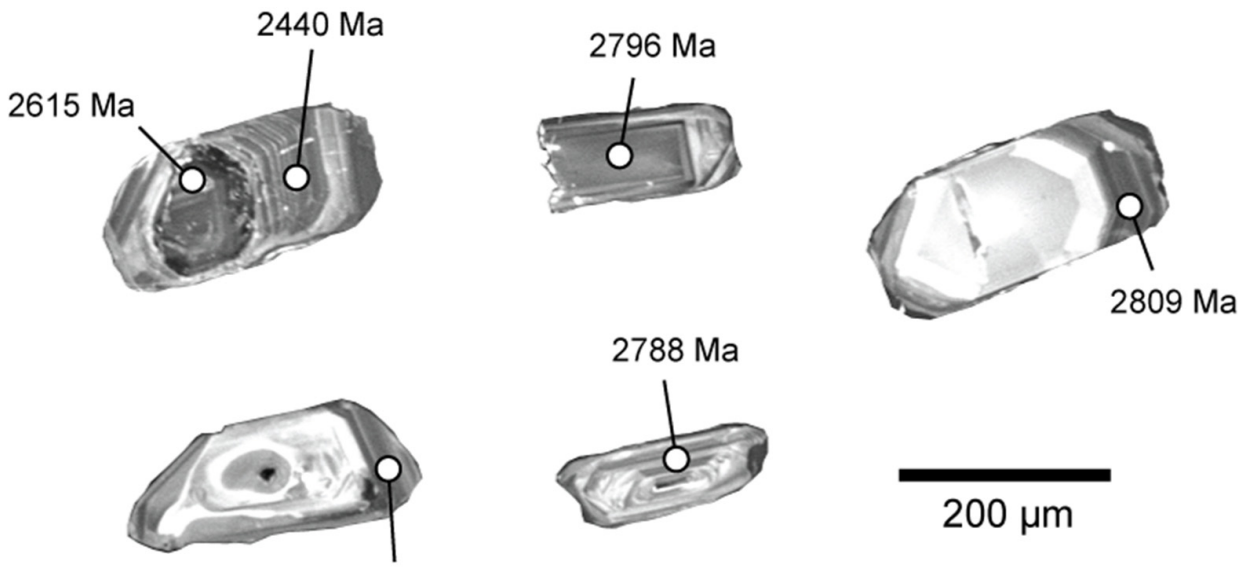

$$
200 \mu \mathrm{m}
$$

$2787 \mathrm{Ma}$

Figura 18 - Idades 207Pb/206Pb de zircões com zoneamento oscilatório (LM10).

Foram realizadas vinte e duas análises dos setores com zoneamento oscilatório. Elas alinham-se em uma discórdia com idade de intercepto superior em $2792 \pm 8 \mathrm{Ma}$ (MSWD = 2,5; Figura 19A). O intercepto inferior fornece uma idade Neoproterozoica (c. $600 \mathrm{Ma}$ ) que atribuímos a um evento térmico posterior que afetou os zircões. Nessa amostra, onze zircões apresentam razões isotópicas concordantes (destaque na Figura 19A), cujo conjunto produz uma idade média ${ }^{207} \mathrm{~Pb} /{ }^{206} \mathrm{~Pb}$ de 2802 $\pm 3 \mathrm{Ma}$ (MSWD = 1,12; Figura 19B). Essa idade não se distingue daquela obtida no intercepto superior quando consideramos os erros analíticos $(2 \sigma)$. Como as análises foram obtidas nos setores com zoneamento oscilatório de origem ígnea (Pidgeon, 1992), a idade média ${ }^{207} \mathrm{~Pb} /{ }^{206} \mathrm{~Pb}$ é considerada a melhor estimativa para a idade de cristalização do ortognaisse. 

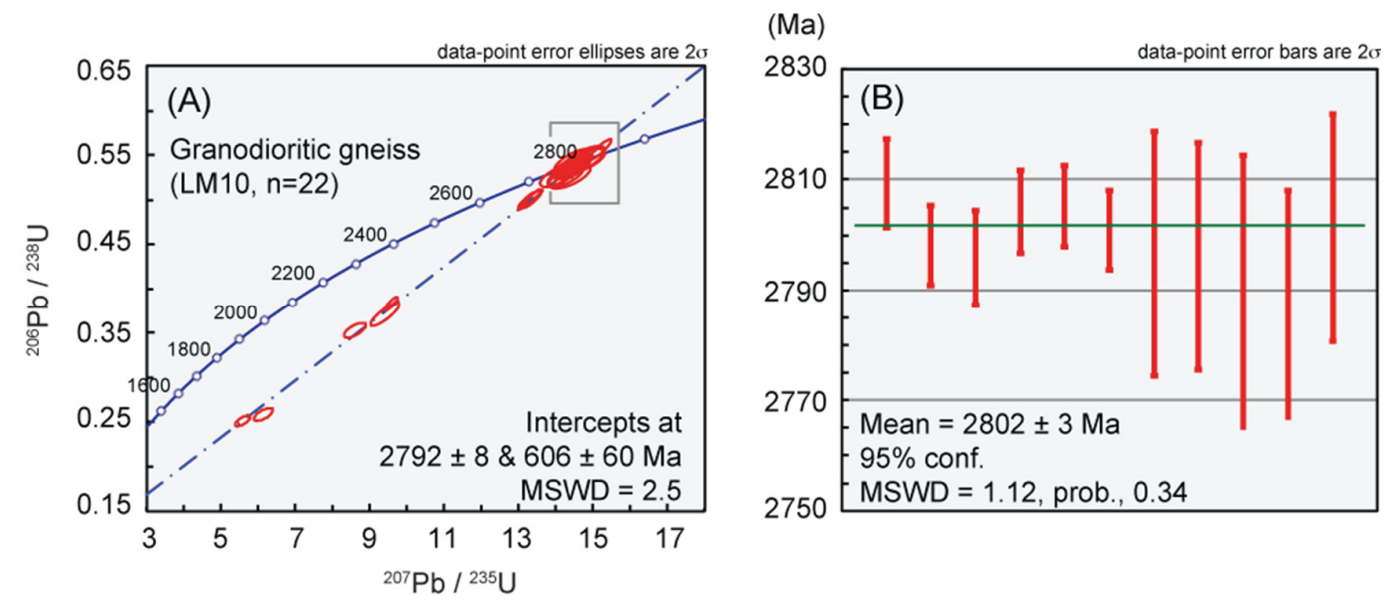

Figura 19 - Diagrama concórdia (A) de zircões de um ortognaisse do Complexo Granjeiro. As análises concordantes (destaque no diagrama) permitem calcular uma idade 207Pb/206Pb média (B) atribuída à cristalização dos zircões. n, número de análises.

Amostra LM2 (UTM 494.442 / 9.252.024 SAD69 Z24S)

O afloramento do qual foi extraído a amostra corresponde a um gnaisse migmatítico estromático, com leucossomas apresentando largura centimétrica e composição quartzo-feldspática. O migmatito encaixa corpos de hornblendito que ocorrem na forma de diques de largura decimétrica a métrica. $\mathrm{O}$ afloramento como um todo está bastante alterado, com as rochas máficas-ultramáficas destacando-se na surperfície como bloco e calhaus de forma arredondada.

A metaultramáfica (Figura 20) possui granulação média a fina e textura nematolepidoblástica dada pela orientação preferencial de anfibólio. É composta por uma matriz a base de clorita (40\%) e talco (35\%), com anfibólio (tremolita, $25 \%$ ) e opacos acessórios (magnetita e hematita, $<1 \%$ ) 


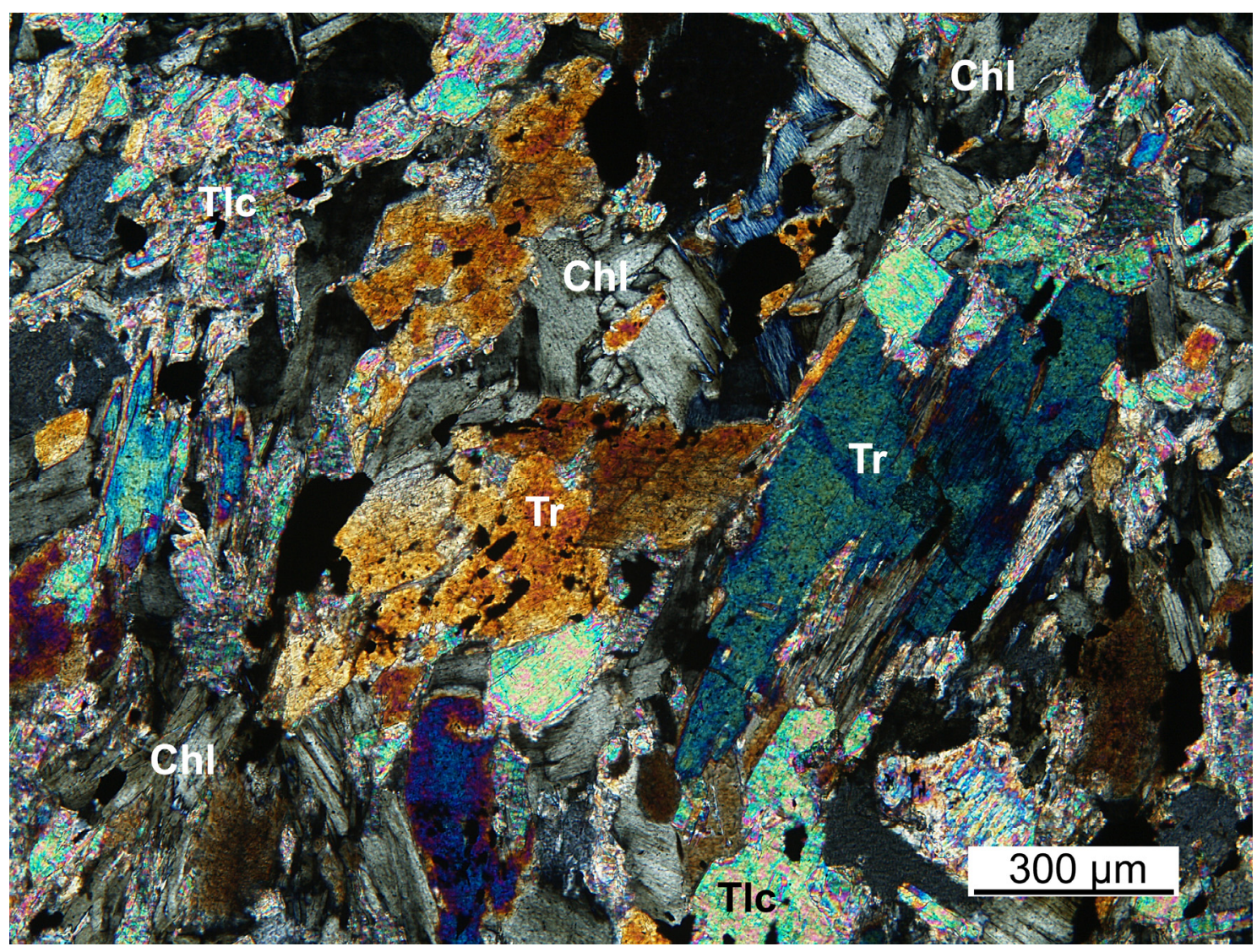

Figura 20 - Microfotografia do ultramafito com textura nematolepidoblástica (Tr, Tremolita; Chl, Clorita; Tlc, Talco). Aumento 10X. Polarizadores cruzados (LM2).

Os zircões selecionados para análise U-Pb possuem tamanho variando de 350 a $100 \mu \mathrm{m}$ e razão axial em torno de 2,5:1; os zircões mais alongados possuem razão axial de até 3,5:1. Os grãos são euédricos e em geral apresentam terminações bipiramidais bem formadas. $\mathrm{Na}$ imagem $\mathrm{CL}$ os zircões exibem uma zonação oscilatória concêntrica a paralela bem definida; alguns grãos apresentam núcleos, em geral mais escuros refletindo um teor de $U$ mais elevado, enquanto outros apresentam bordas mais claras de baixa luminescência.

Foram analisados 20 grãos dos quais três apresentam elevado teor em $\mathrm{Pb}$ comum (\#3.1, \#4.1, \#6.1), duas análises contêm elevado teor de $U$ (> 500 ppm; \#21.1, \#22.1) e duas análises baixa razão Th/U (\#4.1, \#11.1). Descartando essas análises os zircões restantes alinham-se para definir uma idade de intercepto superior em 3026 $\pm 45 \mathrm{Ma}(\mathrm{MSWD}=5.1$; Figura 21). Três zircões que plotam sobre a concórdia fornecem uma idade média ${ }^{207} \mathrm{~Pb} /{ }^{206} \mathrm{~Pb}$ de $3042 \pm 43 \mathrm{Ma}(\mathrm{MSWD}=3,8)$ que, levando 
em conta os erros analíticos, é semelhante a idade de intercepto. Se calcularmos o conjunto de zircões para $2 \sigma$, a idade permanece a mesma porém o MSWD aumenta para 20. O elevado MSWD sugere que os zircões podem não ser cogenéticos (xenocristais). A idade calculada dessa amostra, portanto, deve ser considerada uma idade estimada.

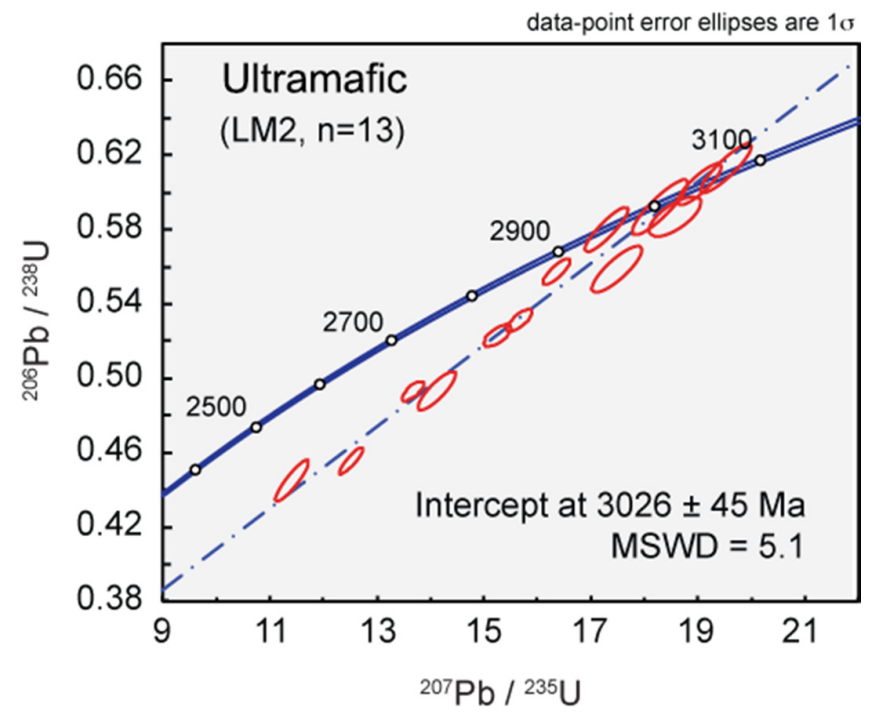

Figura 21 - Diagrama concórdia de zircões de uma ultramáfica associada à gnaisses migmatíticos do Complexo Granjeiro (Povoado Mangabeira, BR-230).

Amostra LM3 (UTM 529.148 / 9.242.040 SAD69 Z24S)

Trata-se de um biotita gnaisse com um bandamento fino marcado pela alternância de faixas relativamente contínuas de tonalidade clara e escura (Figura 22). A amostra selecionada para análise corresponde a um biotita-hornblenda gnaisse de composição granítica, textura granoblástica formada por quartzo (32\%), plagioclásio (12\%), microclina (10\%), biotita (30\%) e hornblenda (15\%). Titanita, opacos, zircão, epídoto e apatita são os principais acessórios. 


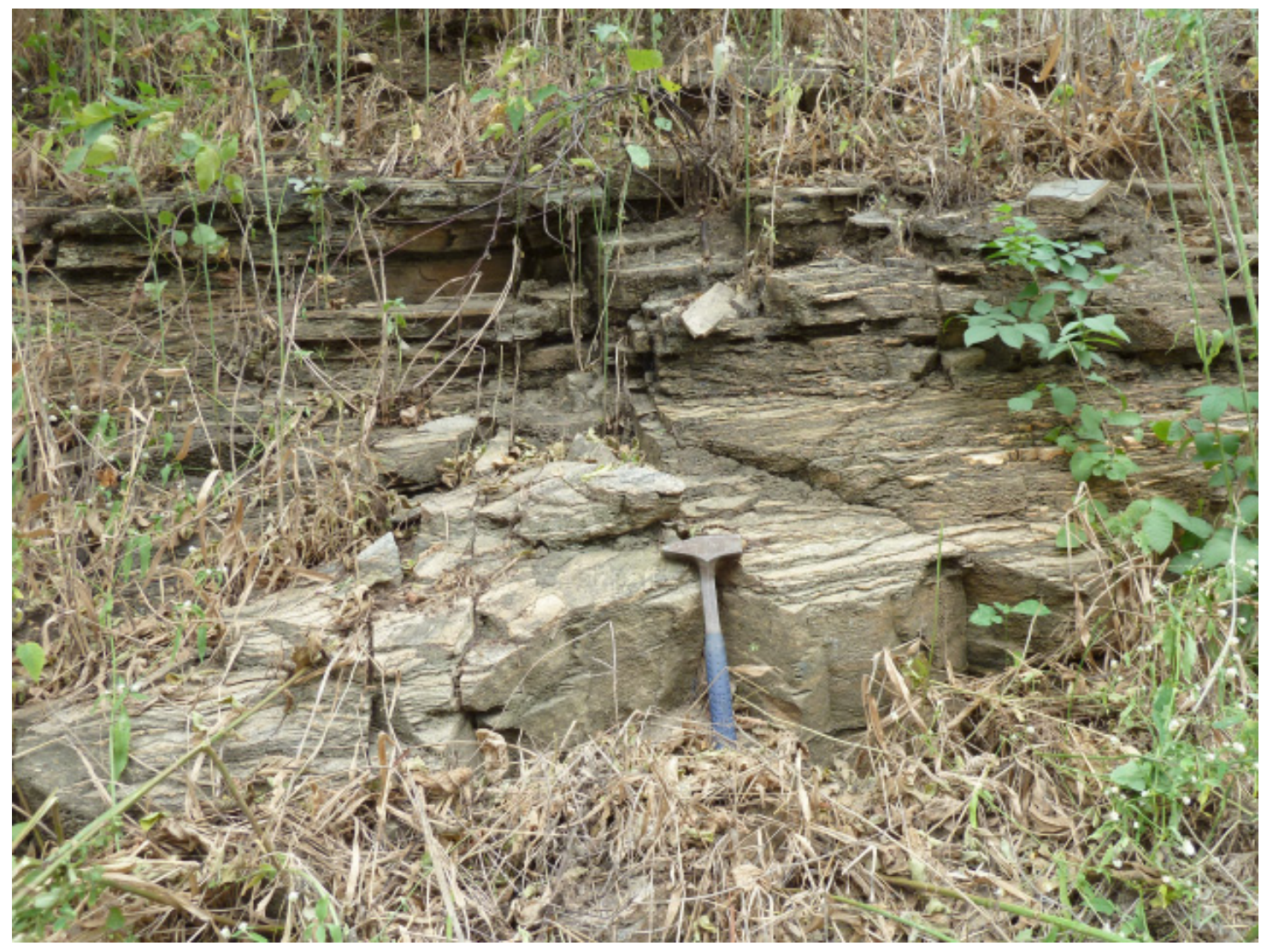

Figura 22 - Gnaisse com fino bandamento caracterizado pela alternância de faixas mais claras e escuras relativamente contínuas (BR-116, sítio Felizardo).

Em torno de 30 zircões foram recuperados, sendo que desses apenas os 13 melhores grãos foram analisados, em dois deles no centro e na borda (\#4 e \#6; ver tabela no anexo A). Os demais grãos apresentam forte metamitização e fraturamento interno, além de aspecto túrbido. Os grãos analisados possuem tamanho variando entre 410 e $70 \mu \mathrm{m}$ e razão axial entre 4:1 e 2:1. As terminações dos cristais são geralmente arredondadas. Internamente são caracterizados por zonação oscilatória, sendo que alguns grãos exibem discreto sobrecrescimento associado à forte luminescência. Treze análises foram feitas nos sítios com zoneamento oscilatório. $O$ comportamento geral das análises é discordante. A melhor discórdia é definida pelo alinhamento de 10 grãos cujo intercepto superior fornece uma idade de $3184 \pm 43 \mathrm{Ma}$ (MSWD = 4.1; Figura 23). Dois grãos com análises no centro e borda mostram comportamentos semelhantes, embora com idade mais jovem na borda. As idades ${ }^{207} \mathrm{~Pb} /{ }^{206} \mathrm{~Pb}$ no centro e borda de um grão (\#6) apresentaram valores semelhantes, em 
torno de 3.0 Ga. Quando calculado para um erro de $2 \sigma$, a idade de intercepto permanece a mesma, porém o MSWD aumenta para 16. A rigor, portanto, a idade fornecida pelo intercepto superior dessa amostra deve ser considerada como uma idade estimada.

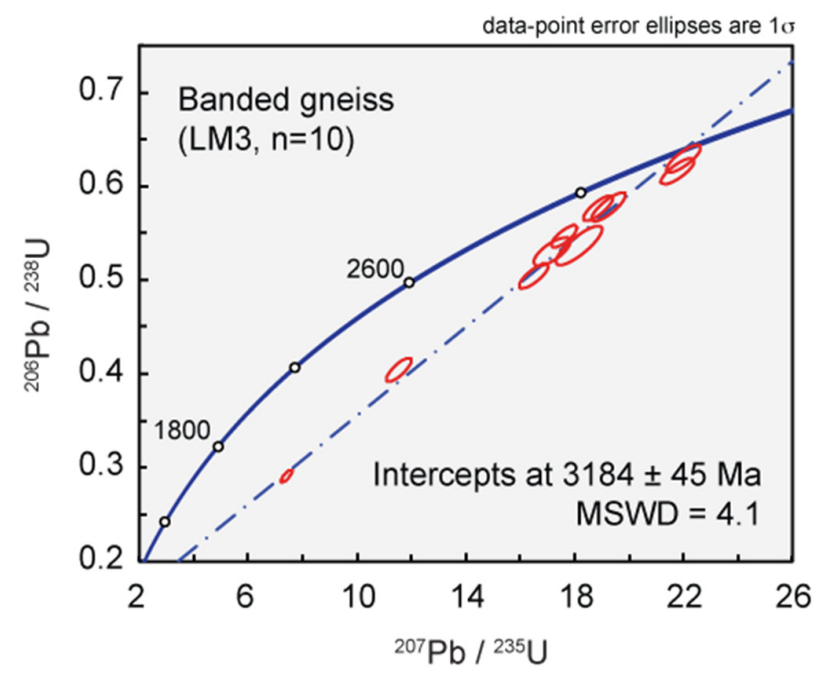

Figura 23 - Diagrama concórdia de zircões de um gnaisse bandado fino pertencente ao Complexo Granjeiro (BR-116, Felizardo).

\subsection{Unidade Paleoproterozoica (Grupo Caicó, Medeiros, 2008)}

Foram coletadas duas amostras na rodovia ligando a cidade de Lavras da Mangabeira à BR-116. Os afloramentos ocorrem em cortes de estrada compreendendo um biotita gnaisse (LM1) e um anfibolito (LM13). Uma terceira amostra, coletada em um augen gnaisse (LM11), situa-se aproximadamente a $2 \mathrm{~km}$ a sul da cidade de Cedro (ver localização na Figura 16).

Amostra LM1 (UTM 507.333 / 9.254.039 SAD69 Z24S)

Consiste de um biotita gnaisse de composição granítica contendo quartzo $(30 \%)$, plagioclásio $(12 \%)$, microclina $(10 \%)$, biotita $(35 \%)$ e hornblenda $(10 \%)$; os minerais acessórios são a titanita (2\%), epídoto, apatita e minerais opacos. A rocha 
apresenta textura lepidogranoblástica média a grossa, com a biotita definindo uma marcante foliação com mergulho para sul; diques de pegmatito de espessura decimétrica métrica cortam a foliação.

Os zircões dessa amostra são euedrais a subeuedrais, muitos deles mostrando terminações bipiramidais. $O$ tamanho dos cristais variam de 100 a $500 \mu \mathrm{m}$ e a razão axial entre variando de 3:1 a 2:1. As imagens de catodoluminescência mostram a presença de zonação ígnea com padrão oscilatório ou setorizado. Algumas bordas de grãos exibem baixa luminescência podendo ser confundidos com recristalização metamórfica, uma vez que a rocha está fortemente deformada. As análises dos sítios com baixa ou elevada luminescência, ou no centro e borda do grão, forneceram idades semelhantes (Figura 24).
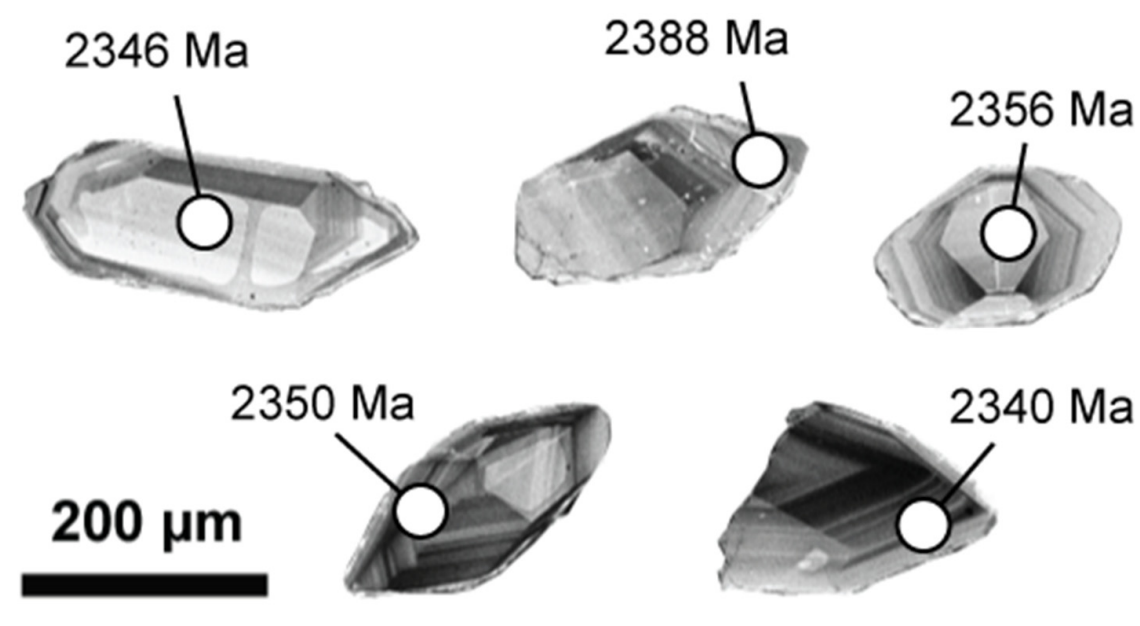

Figura 24 - Idades 207Pb/206Pb de zircões com zoneamento oscilatório (LM1).

Todas as 25 análises nos zircões foram coerentes, com os resultados agrupando próximo à concórdia para fornecer uma idade no intercepto superior de $2356 \pm 12 \mathrm{Ma}$ (MSWD = 0.29; Figura 25). 

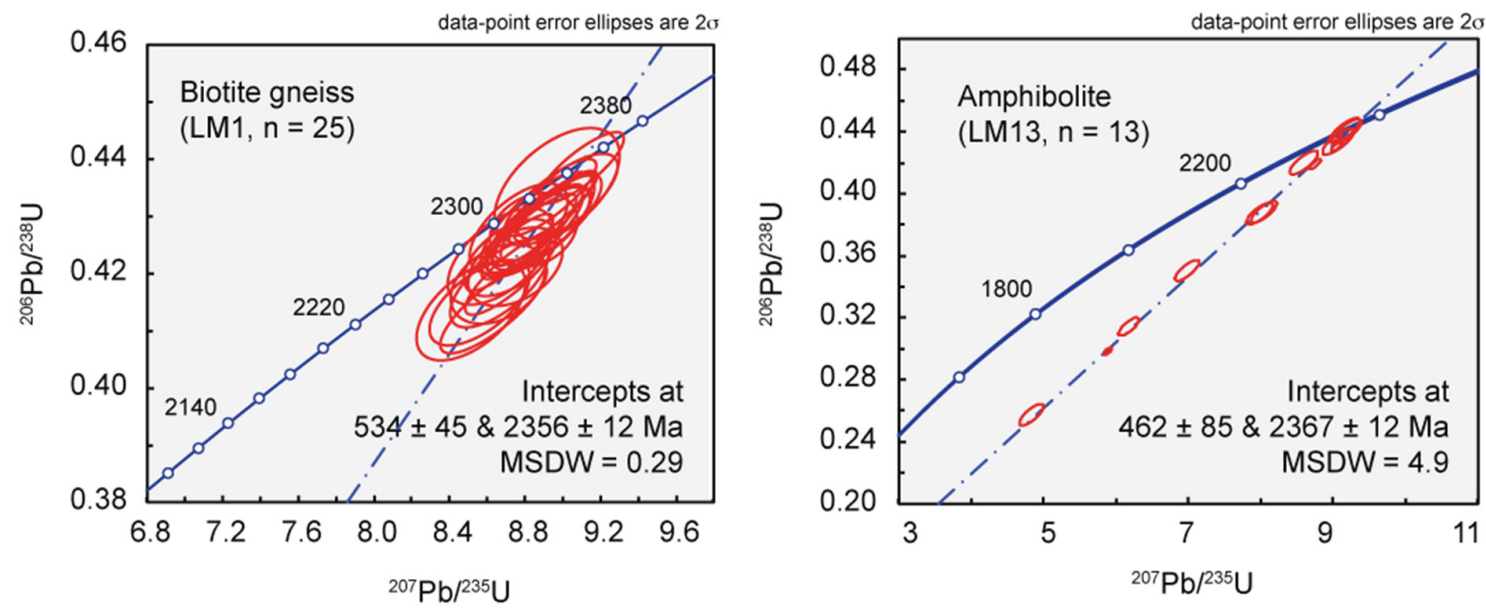

Figura 25 - Diagramas concórdia de zircões de um biotita gnaisse e de anfibolito (BR-230, leste de Lavras da Mangabeira).

Amostra LM13 (UTM 514.020 / 9.252.946 SAD69 Z24S)

Trata-se de um anfibolito de textura nematoblástica, granulação média, localmente cortado por veios pegmatíticos e quartzo-feldspáticos. $O$ anfibolito está em contato com um biotita gnaisse leucocrático. $O$ anfibolito e o gnaisse encaixante estão, contudo, bastante alterados.

Os zircões variam entre 320 e $100 \mu \mathrm{m}$ de comprimento (média de $200 \mu \mathrm{m}$ ) e razão axial entre 4:1 e 1.5:1 (média de 2:1). Alguns grãos apresentam zonamento oscilatório enquanto outros se encontram fortemente metamitizados; esses últimos não foram analisados. De um total de vinte e três análises, uma apresentou elevado teor de $\mathrm{Pb}$ comum (\#22.1) e outras duas, elevado Th/U (\#10.1 e \#15.1) sendo, portanto, descartadas. Do conjunto restante, treze zircões alinham-se para definir uma discórdia com intercepto superior em $2367 \pm 12 \mathrm{Ma}$ (MSWD = 4.9; Figura 25). Essa idade é semelhante à do biotita gnaisse (LM1) confirmam, portanto, a ocorrência de rochas félsicas e máficas siderianas nesse setor do Bloco Assaré. 
Trata-se de um augen gnaisse (Figura 26) caracterizado por fenoclastos de feldspato centimétricos a sub-centimétricos imersos em uma matriz com quartzo, feldspato e biotita. A rocha está bastante alterada. Porfiroclastos estirados de feldspato e palhetas de biotita definem uma foliação com mergulho moderado a suave para sul.

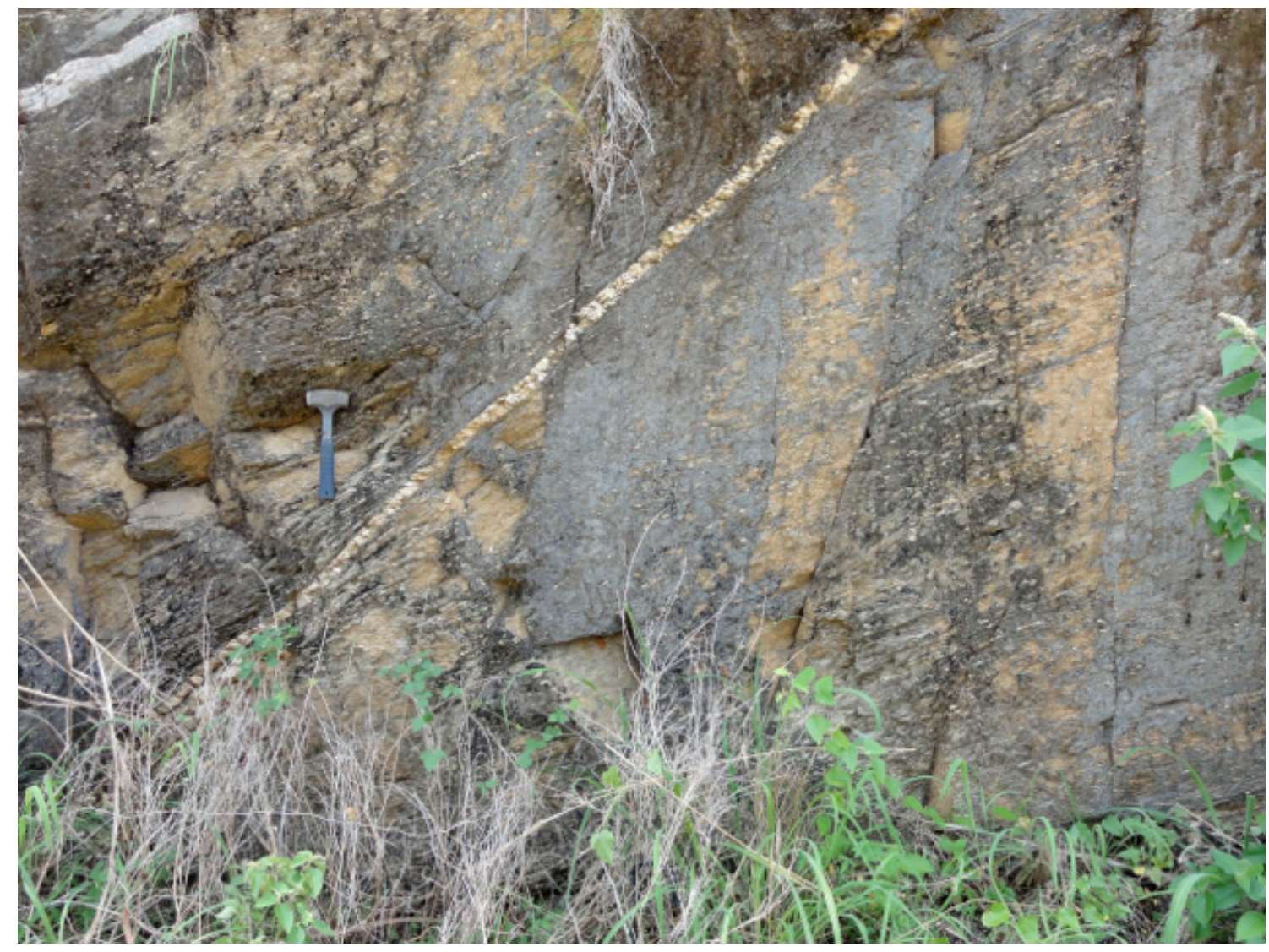

Figura 26 - Augen gnaisse com foliação definida pelo alinhamento de biotita e feldspato estirado mergulhando para sul. A foliação é cortada por dique de pegmatito. (Cedro, CE).

Uma pequena quantidade de zircão foi recuperada da amostra. Eles variam em tamanho de 70 a $550 \mu \mathrm{m}$ e razão axial entre 1,5:1 e 3.5:1. Na imagem CL os zircões exibem zoneamento ígneo, com alguns grãos apresentando regiões centrais de baixa luminescência circundada por setores de alta luminescência. Um total de treze análises foram efetuadas nos grãos, sendo duas análises (\#8.1 e \#12.1) realizadas no 
centro dos grãos com baixa luminescência. Esses núcleos apresentaram idade paleproterozoica, enquanto as regiões mais periféricas de alta luminescência forneceram idades concordantes neoproterozoicas. As demais análises fornecem um padrão discordante que, junto às análises das idades mais jovens, alinham-se em uma discórdia com interceptos superior e inferior de, respectivamente, $2209 \pm 12$ Ma e 589 $\pm 13 \mathrm{Ma}$ (MSWD = 3.0; Figura 27). A idade de intercepto inferior é interpretada como a do evento que, em parte, recristalizou o zircão e deformou a rocha.

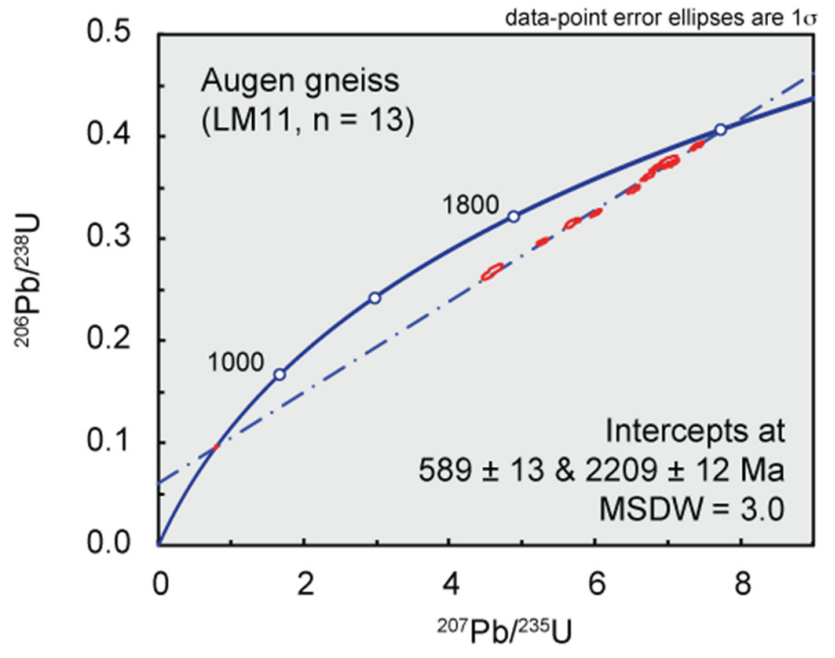

Figura 27 - Diagrama concórdia de zircões de augen gnaisse (ver localização na Figura 16). 


\section{TRAMA CRISTALOGRÁFICA}

\subsection{Apresentação}

As tramas cristalográficas de eixos-c de quartzo (Platina Universal e EBSD) de 6 amostras selecionadas nos milonitos no entorno da lente metapelítica da região de Lavras da Mangabeira (sudeste de Cedro) serão apresentadas na forma de figuras de polo (rede de Schmidt, hemisfério sul) e encontram-se sumarizadas na Figura 29.

.' Rochas sedimentares Fanerozoicas

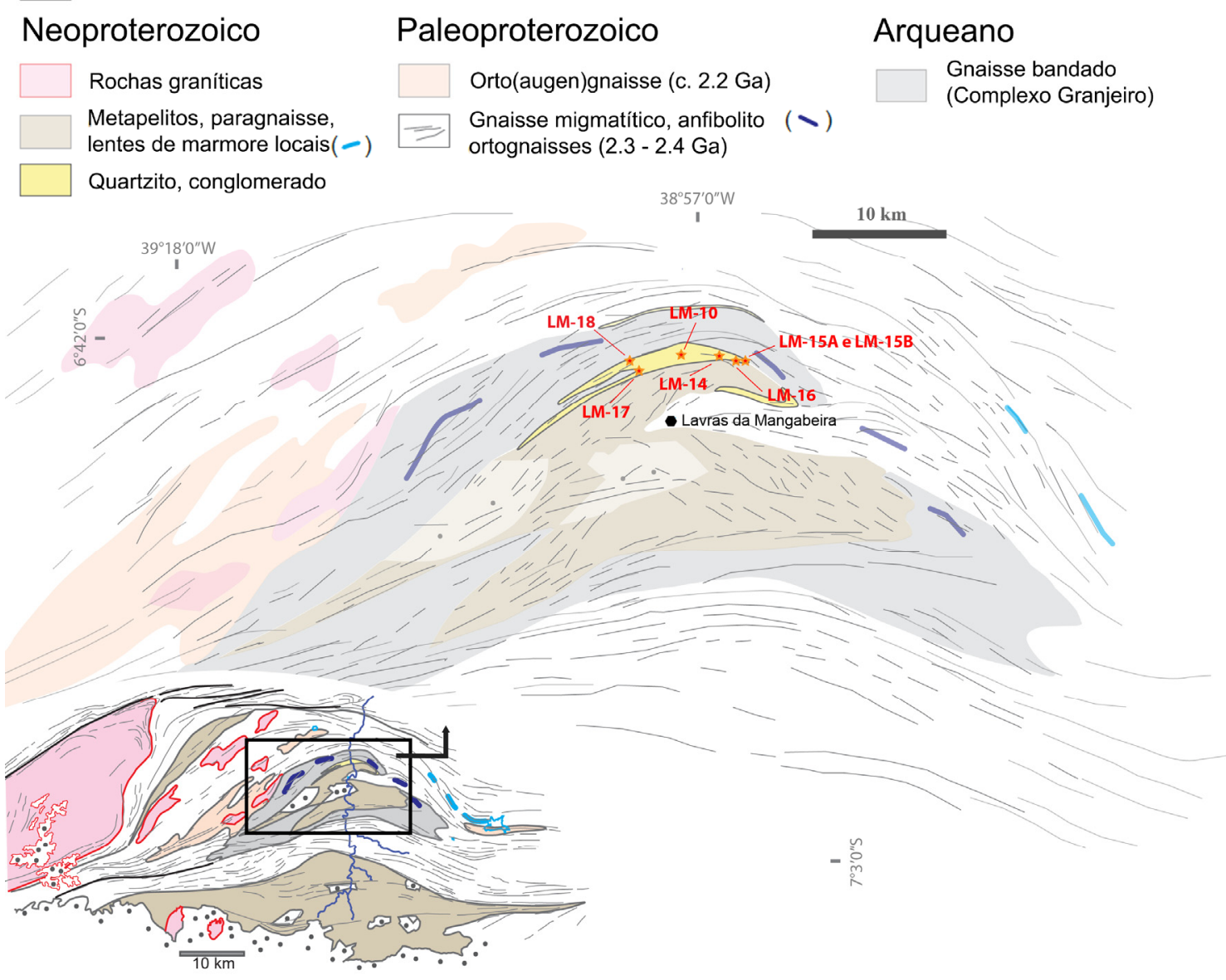

Figura 28 - Localização das amostras coletadas para o estudo de trama cristalográfica no Duplex de Lavras da Mangabeira. Datum WGS 1984. Modificado do Mapa Geológico de Estado do Ceará (1:500.000; Cavalcante et al., 2003). 


\subsection{Classificação das amostras}

As amostras foram classificadas com base no padrão de eixos-c, compreendendo guirlandas de círculo mínimo (small-circle guirdles), guirlandas quebradas (cleft guirdle), simples de círculo máximo assimétricas, cruzadas do tipo I e Il e cruzadas do tipo I assimétricas (Tullis 1977, Lister \& Willians 1979, Lister e Hobbs 1980, Price 1985, Schmid \& Casey 1986 e Paschier e Trouw 1996).

Dois tipos de guirlanda foram obtidos no Duplex de Lavras da Mangabeira: guirlanda cruzada tipo I levemente assimétrica e guirlanda de círculo máximo assimétrico, sendo a assimetria das amostras dominantemente destral.

Guirlandas do tipo I assimétricas (LM-14, LM-17 e LM18) possuem arranjos de eixos-c com concentrações máximas levemente assimétricas, evidenciando tanto uma componente de cisalhamento simples destral quanto forte componente de cisalhamento puro. Os eixos-c nestas amostras concentram-se entre $\mathrm{Y}$ e Z . A amostra LM-18 exibe uma trama de eixos-c de difícil interpretação, exibindo máximos também entre $Y$ e $Z$, entretanto mais próximo de $Y$. No entanto foi classificada como guirlanda cruzada do tipo I com o auxílio da trama cristalográfica de eixos-<a>.

Guirlanda de círculo máximo assimétrico (LM-16) apresenta leve inclinação em direção à foliação e exibe concentração de eixos-c entre $Z$ e Y. Este tipo de padrão caracteriza uma deformação não-coaxial progressiva.

As amostras LM-15A e LM-15B apresentam concentração máxima próxima à lineação mineral, sendo a primeira mais bem definida. Apesar do elevado número de medições via EBSD, essas amostras devem ser consideradas com ressalvas por possuírem um problema estatístico oriundo da grossa granulação (chegam até $5 \mathrm{~mm}$ ) e não oferecem, na limitada área das seções delgadas, uma população de grãos razoável. 


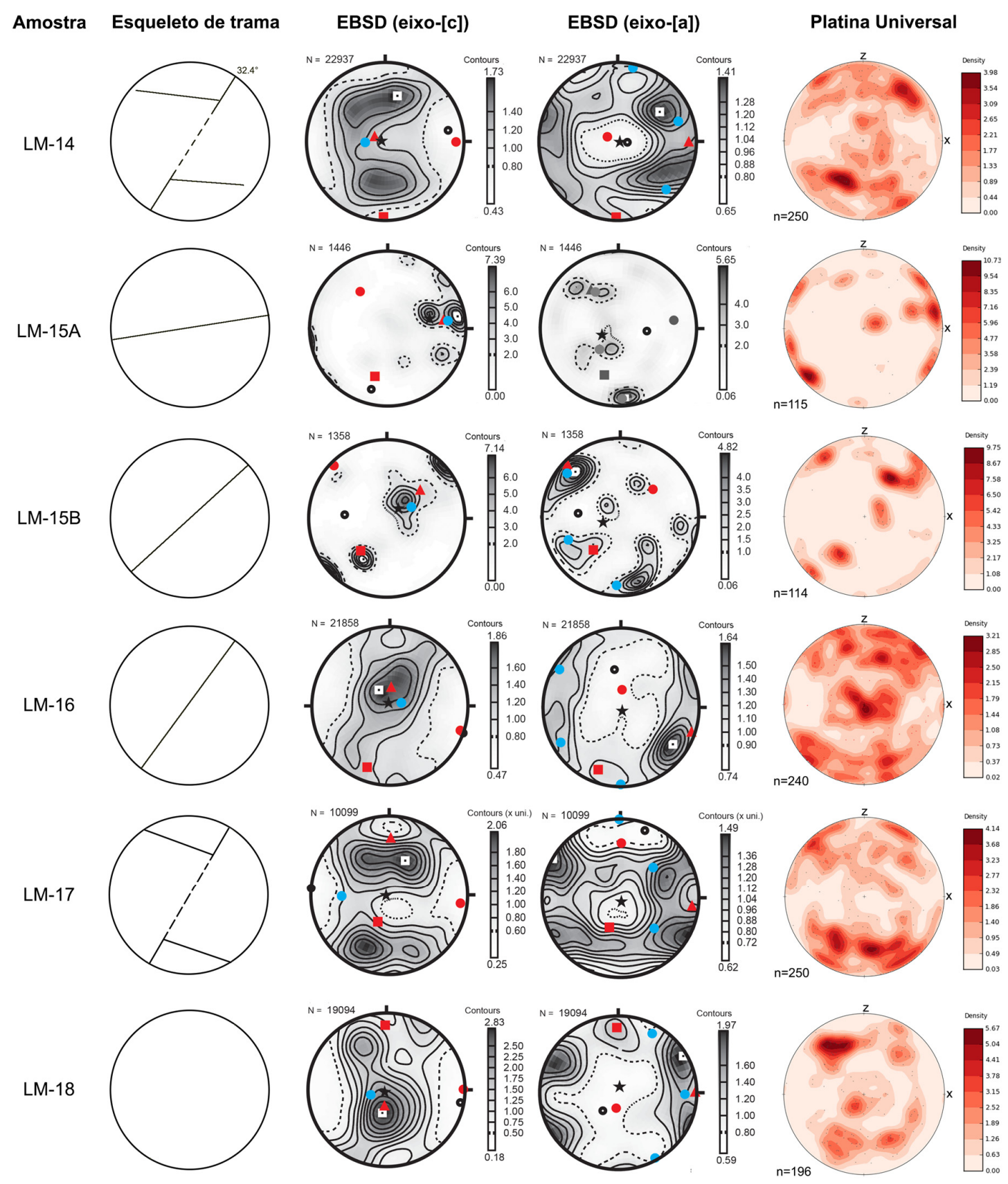

Figura 29 - Trama cristalográfica de eixos-c e eixos-[a] de quartzo em medidas automatizadas de EBSD, medidas manuais de eixos-c em platina universal e esqueleto de trama das amostras analisadas. 


\subsection{Microestruturas e interpretação da trama}

As microestruturas encontradas nas lâminas (Figura 30) corroboram, de certa forma, as condições de temperatura apontadas na análise da trama de eixos-c. $\mathrm{Na}$ amostra LM-16, os grãos de quartzo se encontram organizados dentro de finas bandas. O tamanho do grão, que varia entre 200 - $800 \mu \mathrm{m}$, parece ser sensível à largura das bandas. Portanto, quanto mais larga é a banda, maiores são os grãos que a compõem. As bandas são limitadas, em geral, por uma foliação espaçada definida por muscovita. Apesar do conteúdo micáceo (capaz de absorver a deformação pela facilitação do deslizamento ao longo das bordas e dissolução por pressão), grãos recristalizados de quartzo mostram extinção ondulante, ribbons, bordas de subgrãos e vaga extinção tabuleiro de xadrez (estágio inicial de deslizamentos basal <a> e prisma [C] combinados - Kruhl, 1996), indicando temperaturas superiores a $500^{\circ} \mathrm{C}$. A migração de borda de grãos é o processo dominante de recristalização e também indica temperaturas acima de $500{ }^{\circ} \mathrm{C}$ (Stipp et al., 2002). O crescimento das bordas dos grãos por migração (GBM - grain boundary migration) está registrado por frequentes estruturas pinning (Figura 30c) e pequenas palhetas de mica branca orientadas no interior dos grãos de quartzo.

A amostra LM-14 apresenta agregados (finas camadas ou lentes, Figura 30a) de grãos de quartzo mais grossos (aprox. $230 \mu \mathrm{m}$ ) distintos da matriz definida por muscovita e feldspato potássico (aprox. $100 \mu \mathrm{m}$ ). Os limites dos grãos de quartzo são curvados por migração de bordas. No entanto a poligonização parece ter um papel importante e produz também grãos com limites retos e junções tríplices. Além disso, é frequente a ausência de deformação no interior dos grãos de quartzo, o que possivelmente reflete a diminuição da energia através da acumulação de defeitos intracristalinos na superfície exterior dos retículos, formando paredes de subgrãos ou promovendo a migração de bordas. Outros apresentam extinção ondulante e bordas de subgrãos. Os grãos de K-feldspato exibem geminação da microclina, que podem começar a formar-se logo abaixo de $400^{\circ} \mathrm{C}$ (Passchier \& Trouw, 2005) e geminação em cunha (formadas acima de $400^{\circ} \mathrm{C}$ ). 
As amostras LM-15A e LM-15B possuem grãos de quartzo muito grossos (até $5 \mathrm{~mm}$ ) com bordas lobadas produzidas principalmente por GBM. Localmente as bordas de grãos exibem microestruturas do tipo bulging (Hirth \& Tullis 1992) sobre as bordas lobadas, registrando a diminuição da temperatura durante a deformação com a troca do mecanismo de deformação dominante. Os grãos frequentemente possuem bordas de subgrãos (oblíquos à lineação) e típicos subgrãos tabuleiro de xadrez (Figura 30b) indicativos da transição entre quartzo $\alpha-\beta$ (Kruhl, 1996) e temperaturas de deformação acima de $500^{\circ} \mathrm{C}$. Parte dos grãos antigos foram obliterados por novos grãos pelo processo GMB, sendo ainda possível encontrar restos de grãos antigos. Os grãos novos, no entanto, não aparentam estar livres de deformação indicado pela presença de extinção ondulante, mostrando o contínuo papel da recristalização dinâmica no processo deformacional.

A amostra LM-17 exibe bandas de grãos de quartzo (aprox. $220 \mu \mathrm{m}$ ) separadas por bandas finas compostas essencialmente por feldspato potássico recristalizado (grãos de aprox. $50 \mu \mathrm{m}$ ). Porfiroclastos de K-feldspato (aprox. 1,3 mm, Figura 30d) exibem frequentemente geminação da microclina, estrutura manto-núcleo e dominante sentido destral de cisalhamento. Os grãos alongados de quartzo e microclina são subparalelos à foliação definida pela trama de muscovita. O processo dominante de recristalização no quartzo é GBM formando bordas curvadas e lobadas. Alguns agregados de quartzo recristalizados obliquamente à foliação também são consistentes com uma cinemática destral. Apenas alguns grãos de quartzo mostram extinção ondulante e bordas de subgrãos. Geralmente os grãos de quartzo aparentam-se livres de deformação possivelmente por uma rápida recristalização e recuperação, processos esses dominantes em condições de alto grau (Passchier \& Trouw, 2005). As bandas de feldspato, por sua vez, provavelmente foram originadas da total recristalização de porfiroclastos de feldspato.

A amostra LM-18 possui ribbons de quartzo (Figura 30e) e grãos grossos (aprox. $340 \mu \mathrm{m}$ ) achatados evidenciando, em conjunto com a trama de eixos-c no entorno de Z, a importância da componente de cisalhamento puro característico de uma deformação no campo oblato do diagrama de Flinn. As bordas dos grãos são em parte curvadas e lobadas por GBM e, com menor frequência, retas. Portanto a poligonização também teve um papel no processo de recristalização. Os grãos exibem ainda bordas de subgrãos, bem como extinção ondulante em alguns casos. Ocorrem 
também finas bandas compostas por grãos de K-feldspato recristalizado (aprox. 100 $\mu \mathrm{m})$ conectados a porfiroclastos de microclina com estruturas manto-núcleo.
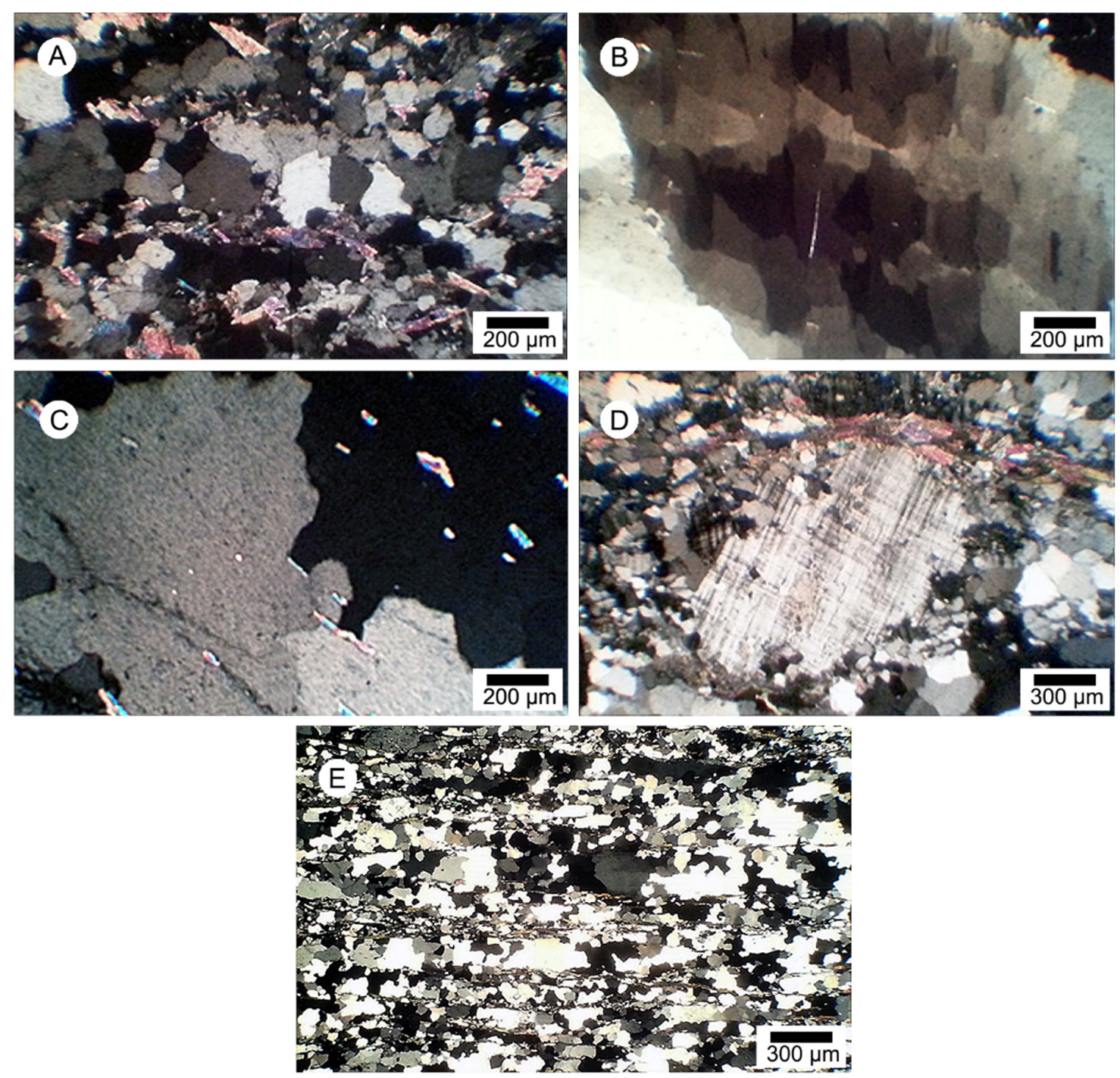

Figura 30 - a) Agregado de quartzo com bordas lobadas em meio a uma matriz de granulação fina composta por feldspatos, mica branca e quartzo (LM-14); b) Subgrãos em extinção tabuleiro de xadrez, típica feição de alto grau em grão de quartzo (LM-15A); c) Estruturas pinning registrando o intenso processo de migração de bordas (LM-16); d) Porfiroclasto de microclina com estrutura manto-núcleo (LM-17); e) Textura geral mostrando ribbons paralelos à foliação em meio a grãos de quartzo com bordas lobadas (LM-18). 
O regime deformacional não-coaxial em que as zonas de cisalhamento do Bloco Assaré foram submetidas deixaram vastos registros da assimetria. Nos quartzo milonitos ao norte de Lavras da Mangabeira, as microestruturas evidenciam o cisalhamento com topo para para ENE (Figura 31). No entanto, as tramas de eixos-c simétricas (LM-17, LM-18) e assimétricas (LM-14, LM-15A, LM-15B, LM-16) confirmam uma deformação composta tanto por uma componente compressional quanto componente de natureza cisalhante, respectivamente, caracterizando um regime transpressional de deformação.

Guirlandas simples ou cruzadas do tipo I com concentrações de eixos-c em torno de $\mathrm{Z}$ e $\mathrm{Y}$ e transição mais próxima de $\mathrm{Y}$ indicam deslizamento dominante de planos romboédricos $\langle a+c\rangle$ e prismáticos na direção do eixo cristalográfico $<a>$, respectivamente. As amostras LM-14, LM-17 e LM-18 possuem concentração de eixos-c no entorno de $Z$ (basal) e entre $Z$ e $Y$, se bem que a amostra LM-18 mostra concentração de eixos-c pouco mais perto de $\mathrm{Y}$, o que pode ser interpretado como uma transição de escorregamentos entre planos romboédricos $\langle a+c\rangle$ e prismático $<a>$. O caráter transitório entre máximos em $Y$ passando para deslizamento nos planos romboédricos e basais sugere uma maior participação da deformação na ativação dos sistemas de deslizamento (Stipp et al., 2002). O deslizamento de planos dominantemente rombo e prisma nessas amostras pode ser correlacionado a uma temperatura em condições de médio grau (Hirth \& Tulis, 1992).

A guirlanda simples assimétrica LM-16 apresenta concentrações máximas de eixos-c entre $Z$ e $Y$, no entorno de $Y$ e também ao redor de $Z$. Propõe-se então a dominância de escorregamentos no sistema romboédrico $\langle a+b\rangle$. Já as guirlandas simples assimétricas das amostras LM-15A e LM15B mostram concentrações de eixos-c no entorno de $\mathrm{Y}$ e uma concentração na periferia do diagrama, próximo à lineação. Elas evidenciam a transição entre escorregamentos de planos prismáticos na direção <a> para planos prismáticos na direção [c], respectivamente. Sabendo que a transição entre a ativação do prisma <a> para o prisma [c] é estimada em temperaturas da ordem de $550-600^{\circ} \mathrm{C}$ (Mainprice et al. 1986; Okudaira et al. 1995), estimamos que as amostras experimentaram deformação sob condições de alto grau com temperaturas acima da linha de transição supracitada. É importante ressaltar que 
estimativa de temperatura pela análise do padrão de eixos-c de quartzo é influenciada por diversos fatores como recristalização, tamanho dos grãos e presença de outros materiais capazes de absorver a deformação. Contudo esses fatores são mais importantes quando a deformação ocorre em condições de baixo grau metamórfico, onde a pressão nas bordas dos grãos facilita a dissolução e precipitação. Entretanto, em média-alta temperatura, a difusão é mais importante e a recristalização ocorre a partir de rearranjo dos átomos no interior do retículo. As tramas cristalográficas das amostras de Lavras da Mangabeira sugerem condições de médio a alto grau. Nesse contexto o mecanismo de deformação dominante seria a fluência de deslocações.

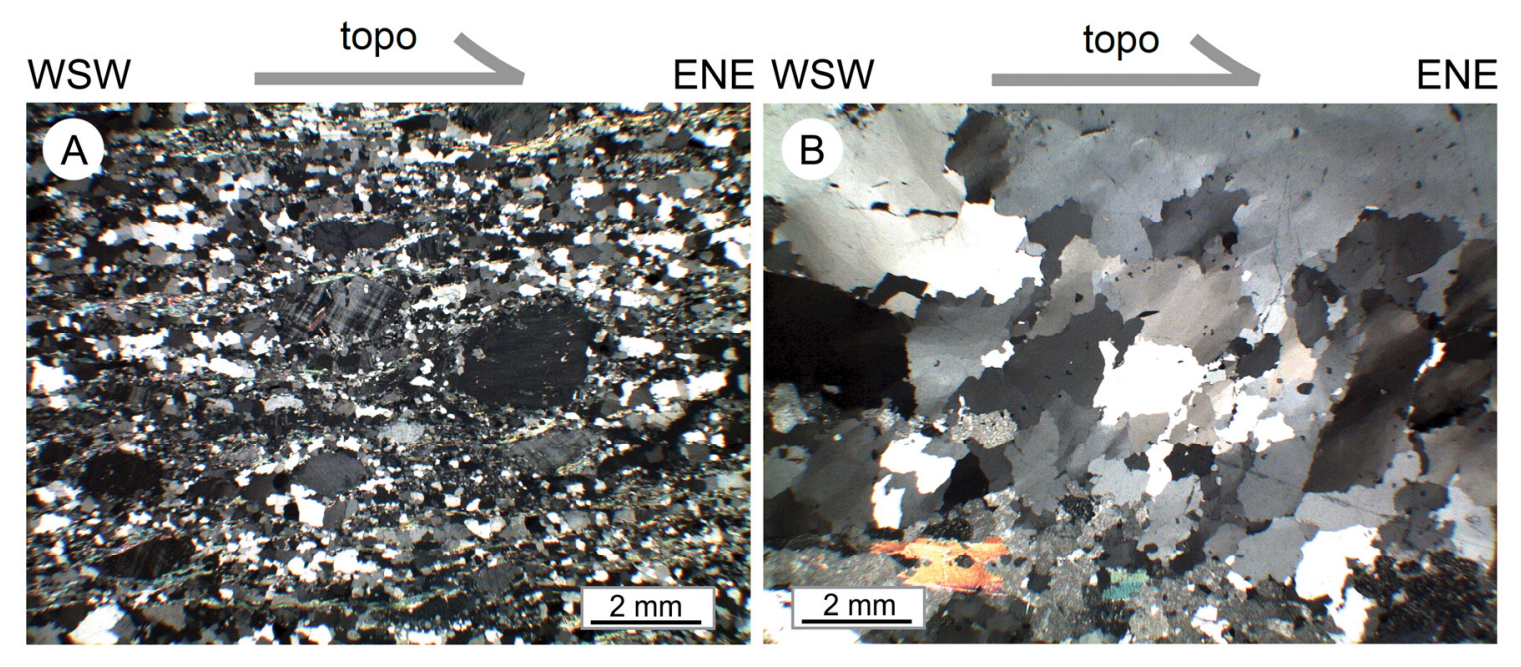

Figura 31 - a) microestrutura marcada por cristais alongados de quartzo e microclina (sub)paralelos à foliação (horizontal) de muscovita. Sombra de pressão e fenoclastos assimétricos indicam cinemática com topo para ENE (LM-17); b) veio de quarto estirado com quartzo recristalizado obliquo ao plano de cisalhamento (horizontal) também são consistentes com topo para ENE.

\subsection{Geotermometria utilizando ângulo de abertura}

De acordo com Kruhl (1998), o ângulo de abertura (OA - Opening Angle) dos padrões de eixos-c de quartzo em tramas deformadas obedecem uma relação linear com a temperatura num intervalo aproximado entre 300 e $650{ }^{\circ} \mathrm{C}$ (Figura 32). Para uma deformação natural, esse ângulo de abertura forneceria temperaturas de deformação com uma incerteza de $\pm 50^{\circ} \mathrm{C}$ devido à influência de taxas de deformação e quantidade de enfraquecimento hidrolítico normalmente presentes em deformações naturais. Entre 650 e $800{ }^{\circ} \mathrm{C}$ existe um incremento maior no ângulo de abertura em 
relação à temperatura, possivelmente em consequência da transição $\alpha-\beta$ do quartzo e dominância na ativação do sistema de deslizamento prismático [c] em detrimento do prismático <a>.

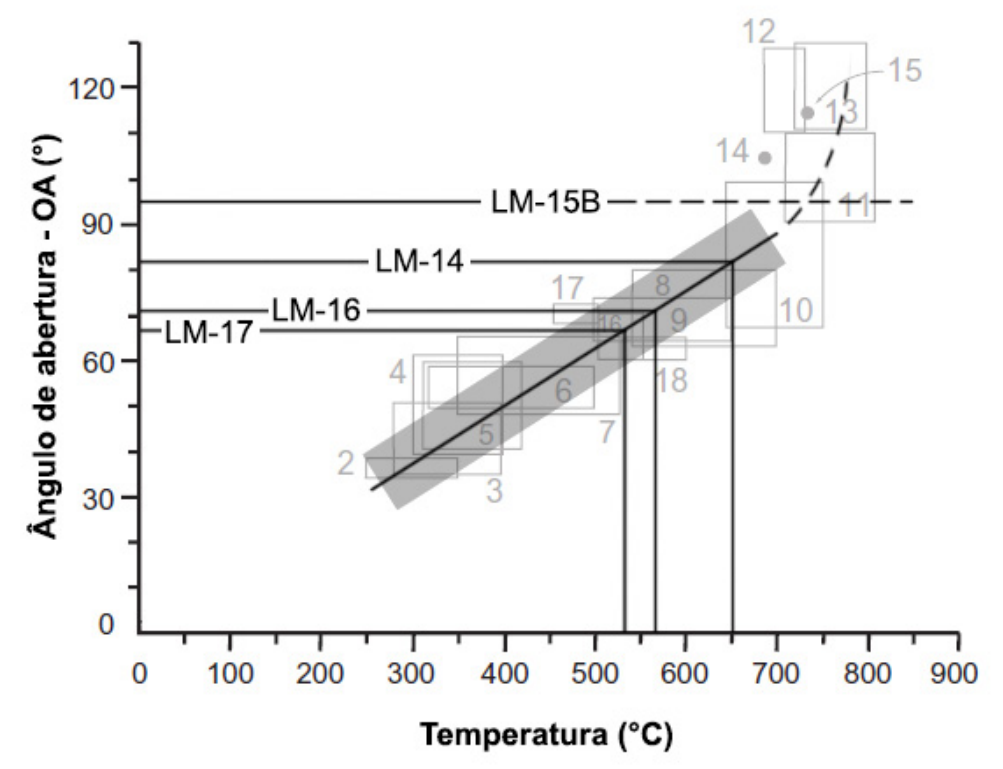

Figura 32 - Gráfico de relação entre ângulo de abertura de trama de eixos-c de quartzo vs. temperatura estimada de deformação adaptado de Law et al. (2004) e pioneiramente proposto por Kruhl (1998). Neles encontram-se plotados os ângulos de abertura das amostras Duplex de Lavras da Mangabeira e suas respectivas temperaturas.

Dentre as amostras, apenas três possuem valores do ângulo de abertura dentro do intervalo de relação linear entre a temperatura e ângulo de abertura. Os valores dos ângulos medidos para as amostras com tramas classificadas como guirlandas simples assimétricas foram espelhados em relação ao plano $\mathrm{YZ}$ e receberam valores duplicados. Por ter trama cristalográfica complexa de difícil interpretação, descartamos a amostra LM-18 desse cálculo (Tabela 6.1). 
Tabela 6.1 - Valores dos ângulos de abertura medidos e temperaturas estimadas através do geotermômetro de Kruhl (1998).

\begin{tabular}{ccc}
\hline Amostra & Ângulo de abertura (OA): & Temperatura \\
\hline$L M-14$ & $81,9^{\circ}$ & $654 \pm 50{ }^{\circ} \mathrm{C}$ \\
$L M-15 A$ & $160,4^{\circ}$ & $>650^{\circ} \mathrm{C}$ \\
$L M-15 B$ & $95,8^{\circ}$ & $>650{ }^{\circ} \mathrm{C}$ \\
$L M-16$ & $71^{\circ}$ & $567 \pm 50^{\circ} \mathrm{C}$ \\
$L M-17$ & $67,4^{\circ}$ & $534 \pm 50^{\circ} \mathrm{C}$ \\
$L M-18$ & - & - \\
\hline
\end{tabular}

Os resultados mostram que as amostras foram deformadas em condições de médio e alto grau metamórfico, sendo a amostra LM-17 a única com temperatura inferior a $500{ }^{\circ} \mathrm{C}$ considerada a margem de erro. Os resultados obtidos corroboram com a análise dos planos ativados e microestruturas e indicam que a deformação no duplex ocorreu em alta temperatura.

\subsection{Geotermetria em bordas suturadas de grãos de quartzo}

Grãos com bordas quartzo-quartzo suturadas podem ser utilizados para calcular a temperatura de deformação (Kruhl \& Nega, 1996). Os contatos suturados que são estatisticamente autossemelhantes entre uma e duas ordens de magnitude podem ser representados por curvas de Koch (Mandelbrot, 1983). As dimensões fractais D (Hausdorff-Besicovitch dimension: Hausdorff, 1919) de bordas de grãos suturados de diferentes graus metamórficos variam entre 1,05 e 1,30 (adimensional), com os valores de $\mathrm{D}$ diminuindo com o aumento da temperatura.

A granulação relativamente grossa do quartzo nas amostras LM-15A e LM15, embora seja um fator limitante na análise da trama eixos-c, permite facilmente a determinação da temperatura deformacional através do estudo da dimensão fractal do contato dos grãos. O método foi aplicado na amostra LM-15B cujos grãos de quartzo exibem contatos suturados nítidos e bem desenvolvidos.

O método Dividers (Stoyan, 1994) é um dos métodos mais simples para estimar a dimensão fractal de linhas irregulares e objetos que possuam um contorno definido. Trata-se de um método exato apenas para curvas autossemelhantes. Ele é baseado 
no fato do perímetro de um fractal ser proporcional ao tamanho de uma régua $(r)$ usada para medir o seu contorno. Inicialmente escolhemos os grãos com as suturas mais longas e livres da influência de feldspato. Estas bordas são vetorizadas manualmente (Figura 33). Os limites vetorizados são transformados em imagens binárias e exportados para o software Benoit 1.3, utilizado para calcular a dimensão fractal D. Utilizando réguas divisoras (Dividers), o programa constrói um gráfico bi-logarítmico que relaciona o comprimento acumulado $(L)$ com o tamanho das réguas $(r)$ e calcula o valor de $D$ interpolando uma equação do tipo $Y=A^{*} e+B^{*} X^{D}$ (Figura 34). É importante observar o tamanho das suturas e selecionar apenas dados válidos de tamanhos de réguas, pois réguas maiores que um terço ou um quarto do tamanho do segmento de uma sutura produzem, no diagrama L-r, dados espalhados e sem significado. Quando as dimensões de r são menores que o segmento reto da curva de Koch, os polígonos se aproximam de um formato euclidiano invalidando assim a relação L-r.

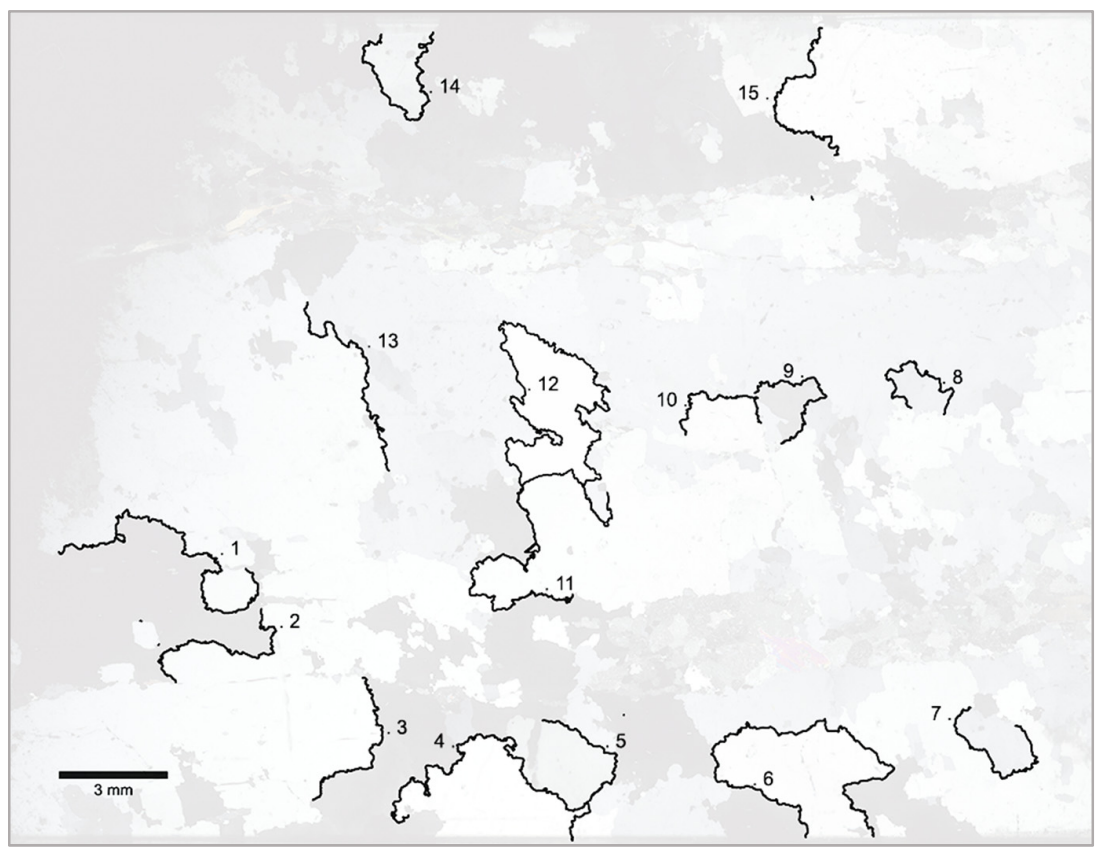

Figura 33 - Aplicação do método Krulh \& Nega (1996) em grãos de quartzo com contato suturado (numerados de 1 a 15). A relação entre o comprimento acumulado (L) vs o comprimento da régua ( $r$ ) utilizado em cada contato permite determinar a dimensão fractal e estimar a temperatura de formação da microestrutura (amostra LM-15B). 

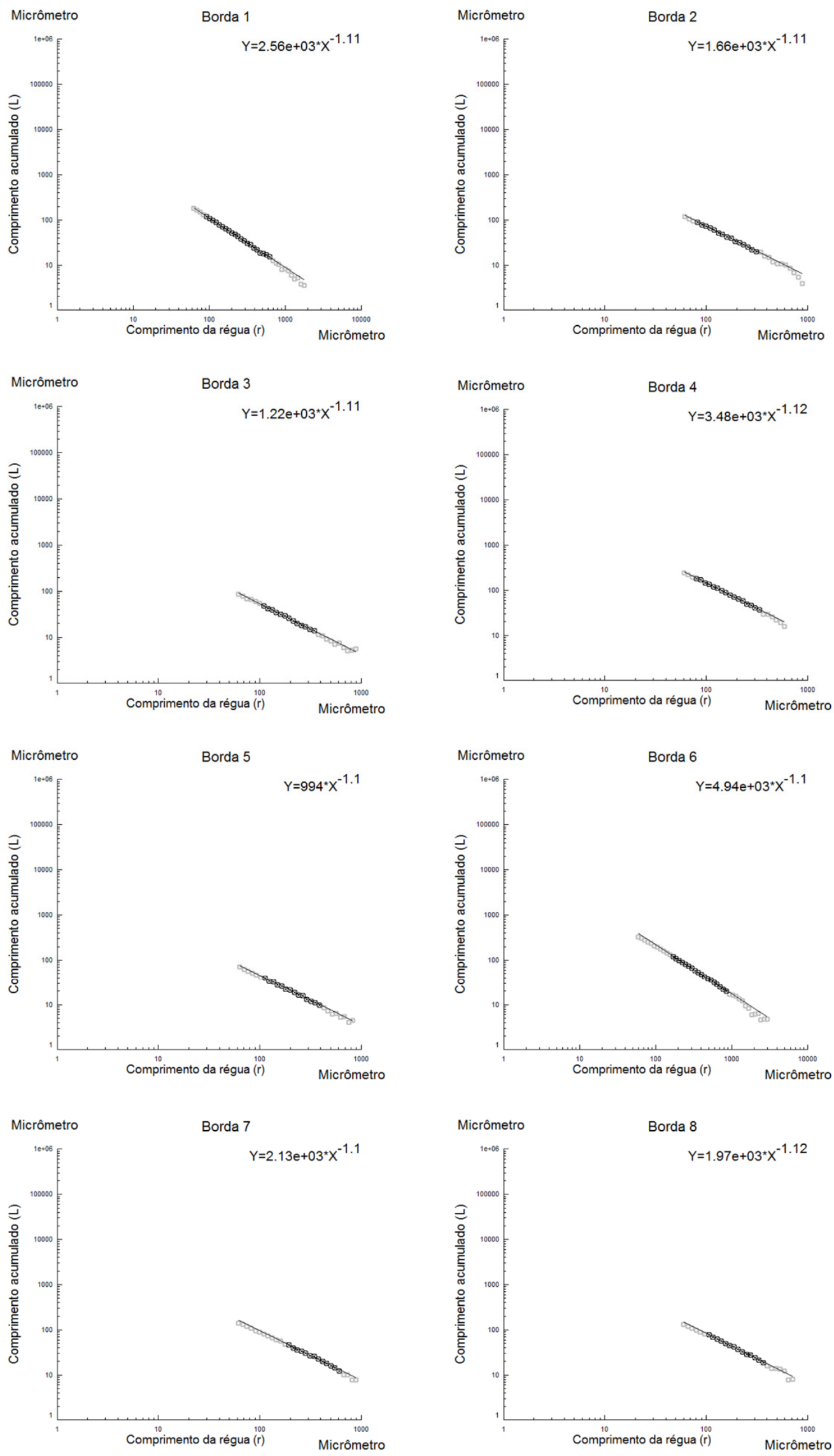

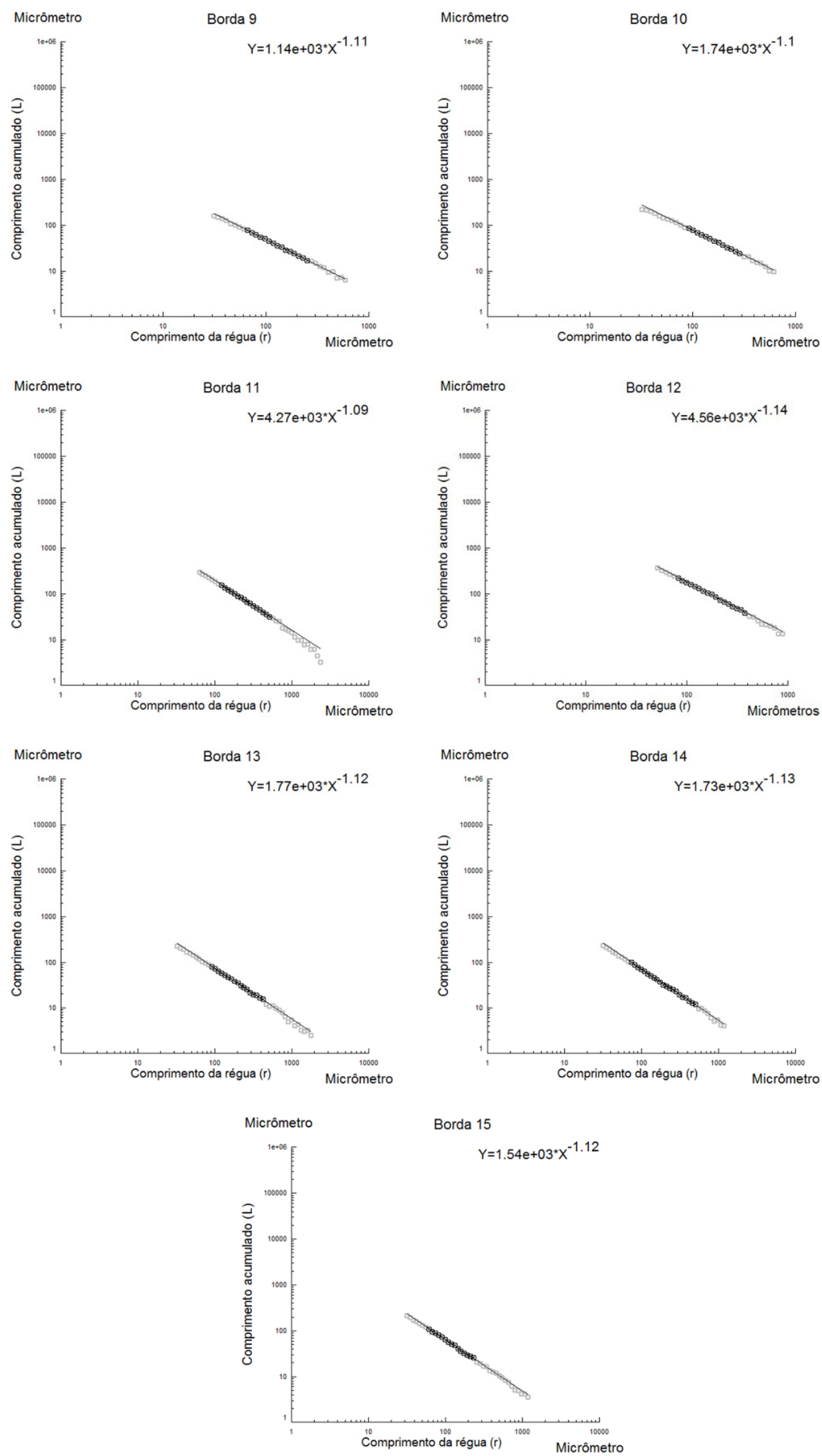

Figura 34 - Relação r-L (escala bi-logarítmica) das bordas vetorizadas (ver Figura 33). A inclinação da reta permite calcular a dimensão fractal $D$ (ver texto). 
Os valores obtidos de D (Tabela 6.2) variam entre 1,103 e 1,119, com o valor médio de $D$ igual a 1,111 (desvio padrão $=0,014,95 \%$ conf.). Plotando os dados no gráfico que relaciona a temperatura de formação das suturas e a dimensão fractal, encontramos uma temperatura da ordem de $662 \pm 50{ }^{\circ} \mathrm{C}$ (Figura 35). Esse valor está de acordo com grau metamórfico indicado pelas microestruturas descritas na amostra LM-15B, e em consistência com a temperatura calculada utilizando o método do ângulo de abertura da trama de eixos-c (cf. Figura 32).

Tabela 6.2 - Resultados da dimensão fractal D para cada borda e respectivo desvio padrão (amostra LM-15B).

\begin{tabular}{ccc}
\hline Borda & Dimensão fractal (D) & $\boldsymbol{\sigma}$ \\
\hline 1 & 1,106 & 0,00231 \\
2 & 1,1071 & 0,00102 \\
3 & 1,1064 & 0,00155 \\
4 & 1,1218 & 0,00075 \\
5 & 1,1006 & 0,0023 \\
6 & 1,0986 & 0,00089 \\
7 & 1,0985 & 0,00272 \\
8 & 1,1201 & 0,00102 \\
9 & 1,1122 & 0,0006 \\
10 & 1,0966 & 0,00045 \\
11 & 1,0892 & 0,00082 \\
12 & 1,143 & 0,00082 \\
13 & 1,1174 & 0,00178 \\
14 & 1,1277 & 0,00208 \\
15 & 1,1224 & 0,00163 \\
\hline
\end{tabular}



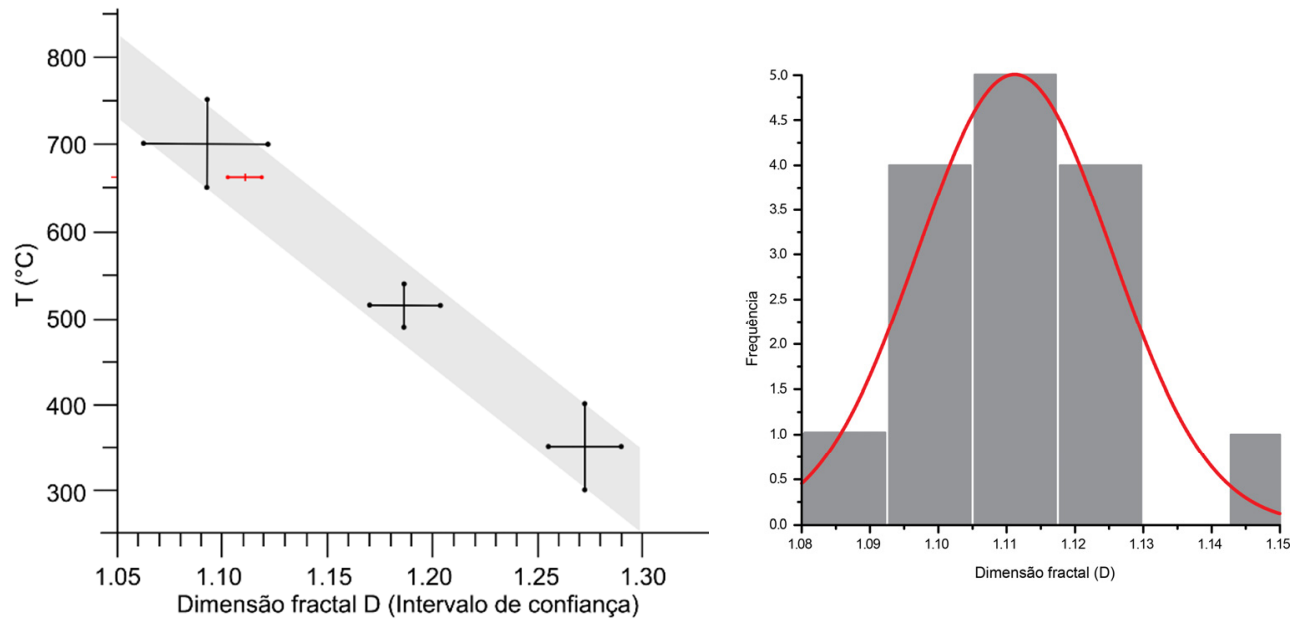

Figura 35 - Gráfico de relação entre a dimensão fractal $D$ e a temperatura de formação das bordas suturadas, à esquerda, modificado de Kruhl \& Nega (1996). Os dados obtidos encontram-se em vermelho no gráfico. À direita, histograma com a distribuição normal das dimensões fractais $D$ encontradas. 


\section{DISCUSSÃO}

\subsection{Geocronologia}

As razões isotópicas sistema U-Pb foram medidas nos setores dos zircões com zoneamento setorizado ou oscilatório. Essas texturas, identificadas principalmente através da catodoluminescência, são caracterizadas por bandas ricas em urânio (faixas escuras na $\mathrm{CL}$ ) que se alternam com bandas mais pobres em urânio (faixas claras). Esse zoneamento tem sido tradicionalmente atribuído ao crescimento do grão em ambiente magmático (Pidgeon, 1992; Harley et al., 2007). Dessa forma, a idade U-Pb obtida nas amostras do Bloco Assaré referem-se às idades de cristalização dos zircões.

No entanto, essas rochas foram variavelmente deformadas e metamorfizadas. Evidências de migmatização foram encontradas em rochas do Complexo Granjeiro (Figura 17). Além disso, as amostras que forneceram idades paleoproterozoicas (LM1 e LM13) exibem uma forte deformação marcada por penetrativa foliação de biotita e feldspato, geralmente truncada por veios quartzo-feldspáticos e pegmatíticos (Figura 26). Por sua vez os dados analíticos são consistentes com uma deformação e metamorfismo ocorridos no Neoproterozoico, como indicam as idades de intercepto inferior das amostras LM10 (Figura 19), LM1 e LM13 (Figura 25), e LM11 (Figura 27). Nessa última amostra, foram obtidas idades concordantes em zircão em torno de 600 Ma. Esse dado indica que o augen gnaisse foi formado no Riaciano enquanto o evento que deformou e metamorfizou o protólito granítico ocorreu no Ediacarano.

As idades U-Pb em zircão no bloco Assaré estão sumarizadas na Figura 36 . O estudo pioneiro de Silva et al. (1997) encontrou uma idade neoarquena (2.54 Ga) em gnaisses bandados situados a sul da cidade de Granjeiro (CE) e riaciana (2.19 Ga) em augen gnaisses situados na cidade de Várzea Alegre (CE). No Mapa Geológico do Estado do Ceará (Cavalcante et al., 2003) o "Complexo Granjeiro" foi definido como uma sequência de ortognaisses, metaultramáficas, anfibolitos e supracrustais, esta última principalmente de origem vulcanogênica. Essa sequência estaria posicionada 
em contato tectônico com uma unidade metaplutônica que inclui intrusões paleoproterozoicas (agora ortognaisses) e granitóides neoproterozoicos. Sobre as unidades do embasamento foram depositados sequências terrígenas neoproterozoicas agrupadas no mica-xisto Caipú e quartzitos, xistos e filitos do Grupo Lavras da Mangabeira (Fetter, 1999; Bautista 2012).

. Rochas fanerozoicas sedimentares

Neoproterozoico Paleoproterozoico Arqueano

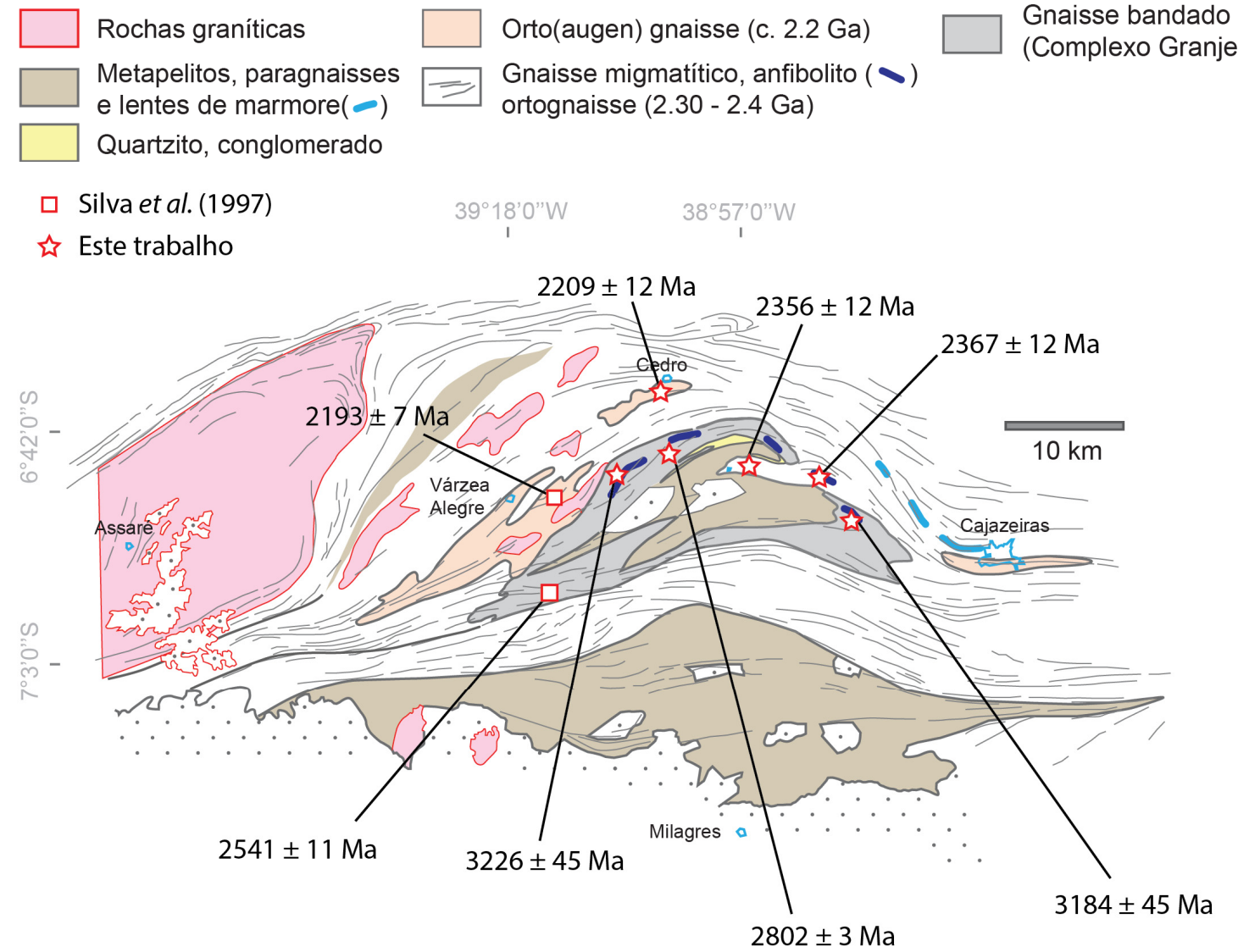

Figura 36 - Resumo das idades U-Pb em zircão para as sequências de embasamento do Bloco Assaré.

Os resultados confirmam uma idade arqueana do Complexo Granjeiro. Os zircões da amostra LM10 forneceram uma idade precisa em c. $2.8 \mathrm{Ga}(\mathrm{MSWD}=1,12$, $2 \sigma)$ que consideramos a melhor estimativa para a cristalização do ortognaisse. Duas outras amostras, uma metaultramáfica (LM2) e um gnaisse bandado fino (LM3) forneceram idades em torno de $3.2 \mathrm{Ga}$. Porém, neste caso, a precisão da idade é comprometida pelo elevado MSWD (> 15;2 $\sigma)$, o que sugere uma população 
heterogênea (herança ?) de zircão. No entanto, e em que pese a imprecisão analítica, a distribuição das análises no diagrama de concórdia sugere claramente que essas amostras foram formadas no arqueano.

Idades siderianas e riacianas foram encontradas em gnaisses e anfibolitos a oeste de Cajazeiras (Figura 36) e em augen gnaisses a sul de Cedro, respectivamente. A presença de rochas siderianas no Bloco Assaré apoia-se na análise do biotita gnaisse (LM1) que forneceu uma idade precisa em c. $2.36 \mathrm{Ga}$ (MSWD $=0,29,2 \sigma)$. O anfibolito, embora contendo uma população de zircão

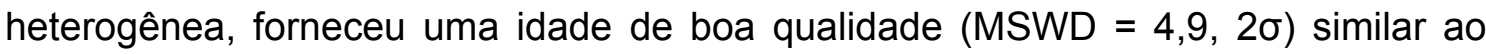
biotita gnaisse. Como essas duas amostras estão relativamente próximas uma da outra, estimamos que o anfibolito represente uma intrusão máfica na encaixante ortognáissica.

O augen gnaisse (LM11) fornece uma idade de c. $2.21 \mathrm{Ga}$. Embora a qualidade analítica não seja das melhores $(M S W D=3,1 \sigma)$, a rocha e a respectiva idade são semelhantes ao augen gnaisse de Várzea Alegre datado em 2.19 Ga (Silva et al., 1997). De acordo com o contexto regional, os augen gnaisses podem ser interpretados como intrusões graníticas tanto nas unidades siderianas como em metaplutônicas riacianas do Complexo Caicó. Os dados analíticos extraídos dos zircões mostram que a deformação e metamorfismo do Bloco Assaré, incluindo as coberturas psamo-pelíticas, ocorreram no Ediacarano durante o ciclo Brasiliano.

\subsection{Petrotrama de quartzo e deformação}

O arcabouço lito-estratigráfico do duplex, conforme indicam as idades das sequências imbricadas, consiste numa cobertura metassedimentar neoproterozoica repousando sobre diferentes unidades rochosas justapostas com idades em torno de 2.2 Ga, 2.35 Ga e entre 2.5 - 3.2 Ga. Essas unidades se organizam em uma geometria do tipo flor positiva assimétrica (Figura 37), com os milonitos verticalizados do setor sul da estrutura correspondendo ao Lineamento Patos. O contato do embasamento paleoproterozoico e arqueno com os quartzitos e conglomerados situados na base da sequência metassedimentar mergulha para sul no setor norte da estrutura. A foliação, 
tanto nos quartzitos como nos mica xistos sotopostos, associa-se a um dobramento recumbente a invertido com vergência para norte. A lineação de intersecção entre o bandamento composicional nos quartzitos e a foliação regional, bem como o estiramento de agregados de quartzo é sub-horizontal de direção NE a ENE. Os critérios cinemáticos observados em porfiroclastos de quartzo com sombra de pressão assimétrica indicam que a sequência metassedimentar moveu-se para ENE comparada ao seu embasamento gnáissico (Figura 31).

NEOPROTEROZOICO

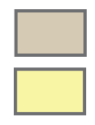

Metapelito

Quartzito, conglomerado

PALEOPROTEROZOICO

Metaplutônicas, augen gnaisse (c. $2.20 \mathrm{Ga}$ )

Gnaisse e anfibolito (c. $2.35 \mathrm{Ga}$ )

ARQUEANO (Complexo Granjeiro)

Gnaisse bandado, ortognaisse tonalítico-granodiorítico,

anfibolito, metaultramáfica $(2.5-3.2 \mathrm{Ga})$

Figura 37 - Perfil esquemático $N$-S do duplex transcorrente estruturado em flor positiva assimétrica. $O$ mergulho da foliação cresce à medida que se aproxima da zona de cisalhamento vertical transcorrente destral de Patos (LP). No modelo proposto, a foliação converge e enraíza-se na zona de cisalhamento principal.

Segundo Corsini et al. (1996), o duplex transcorrente se formara devido a uma perturbação no campo cinemático associado à mudança de fluxo de rochas de NESW para EW. Datações deste presente trabalho e de Silva et al. (1997) indicam a presença de rochas arqueanos no interior do duplex, o que pode ter contribuído para a perturbação do campo deformação local e desenvolvimento das escamas imbricadas. As rochas arqueanas nesse caso atuariam como litotipos de maior competência (mais frios ?) levando a formação de instabilidades mecânicas durante a deformação cisalhante e o consequente cavalgamento dos diferentes conjuntos litológicos. 
A trama de eixos-c dos quartzitos situados próximos ao contato com o embasamento gnáissico variam de simétricas (LM-17, LM-18) a assimétricas (LM-14, LM-15A, LM-15B, LM-16). Esse arranjo da trama é interpretado como resultante de uma deformação híbrida de natureza coaxial e não-coaxial, respectivamente. Esse regime deformacional registrado na trama reforça o modelo transpressional postulado por Corsini et al. (1996), sendo ainda corroborado por outros indicadores tais como dobramentos no interior das lentes e lineação oblíqua. Essas feições caracterizam uma componente de empurrão subsidiária no interior das zonas de cisalhamento que delimitam as unidades imbricadas. A cinemática registrada na assimetria das tramas de eixos-c e microestruturas é compatível com uma movimentação dominantemente destral.

Para Corsini et al. (1996), a deformação do duplex transcorrente se deu em condições retrógradas, inicialmente em condições de alto grau. No entanto, os padrões de eixos-c com concentrações máximas entre $Z$ e $Y$ e próximas de $Y$ nas amostras estudadas indicam que a deformação ocorreu sob condições de médio a alto grau. Os ângulos de abertura das tramas de eixos-c e bordas de grãos suturados de quartzo estão em conformidade com as mesmas condições metamórficas durante a deformação. As amostras LM-15B e LM15A aparentam ter sido deformadas sob temperaturas entre 600 e $700{ }^{\circ} \mathrm{C}$, isto é, um pouco mais altas do que as demais amostras. Sobrepondo-se às longas suturas das bordas de quartzo migradas aparecem, em menor escala, pequenas suturas formadas por bulging indicando a superposição dos processos de recristalização dinâmica. A superposição de processos de alta temperatura sobre os de mais baixas temperaturas (BLG sobre GBM) indicam condições retrógradas de metamorfismo durante a deformação.

Os milonitos do duplex de Lavras da Mangabeira possuem microestruturas semelhantes à sua porção central descritos em Viegas et al. (2014). Esses autores documentaram suturas de alta temperatura, paredes de subgrãos e quartzo fitado de granulação grossa em milonitos associados a migmatitos, que indicam uma deformação por mecanismo de fluência de deslocações em alta temperatura. Adicionalmente, descreve a ativação do sistema de escorregamento prisma <a> e rombo <a+c> no quartzo, típicos de deformação em condições de alto grau e taxas de deformação crescentes. A deformação por fluxo granular em meio parcialmente 
fundido descrita em Viegas et al. (2014) não atuou nos quartzo milonitos estudados neste trabalho. 


\section{CONCLUSÃO}

A caracterização geocronológica (U-Pb em zircão, LA-ICP-MS) das lentes imbricadas define a presença de rochas arqueanas, bem como siderianas e riacianas no interior do duplex transcorrente de Lavras da Mangabeira. As datações complementam e enriquecem o conhecimento da região, até então ainda pouco pesquisada. O estudo geocronológico mostrou que as idades do Complexo Granjeiro variam entre 2,5 e 3,2 Ga. O complexo está em contato alóctone com sequências metassedimentares neoproterozoicas e com gnaisses e anfibolitos datados em torno de $2.35 \mathrm{Ga}$. Orto(augen)gnaisses (c. $2.2 \mathrm{Ga}$ ) aparentemente estão encaixados nas rochas siderianas como também ocorrem ao longo do contato entre o Complexo Granjeiro e a sequência metassedimentar. A presença de rochas arqueanas, rígidas e possivelmente mais frias, situadas precisamente na conexão das grandes zonas de cisalhamento Tatajuba (NE-SW) e Patos (E-W), sugerem que tanto a competência variável dos litotipos quanto a geometria do sistema de cisalhamento teriam sido responsáveis pelo imbricamento das unidades nesse setor do lineamento. $O$ estudo das tramas de eixos-c de quartzo milonitos e suas microstruturas indicam que as escamas imbricadas foram submetidas a regime de deformação transpressional. Utilizando o ângulo de abertura da trama eixos-c e assumindo o modelo fractal do contato suturado de grãos de quartzo, inferimos que os milonitos se deformaram, respectivamente, em temperaturas da ordem de $600 \pm 50$ e $662 \pm 50{ }^{\circ} \mathrm{C}$. 


\section{REFERÊNCIAS BIBLIOGRÁFICAS}

Almeida, F.F.M. de, Hasui, Y., Brito Neves, B.B., Fuck, R.A., 1977. Províncias Estruturais Brasileiras. In: Simpósio de Geologia do Nordeste, 8, Campina Grande, Atas, p. 363-391.

Amaral, W.S., Santos, T.J.S., Wernick, E., Nogueira Neto, J.A., Dantas, E.L., Matteini, M., 2012. High-pressure granulites from Cariré, Borborema Province, NE Brazil: tectonic setting, metamorphic conditions and $\mathrm{U}-\mathrm{Pb}, \mathrm{Lu}-\mathrm{Hf}$ and $\mathrm{Sm}-\mathrm{Nd}$ geochronology. Gondwana Research 22, 892-909.

Archanjo, C.J., Viegas, L.G., Hollanda, M.H.B.M., Souza, L.C., Liu, D., 2013. Timing ofthe HT/LP transpression in the Neoproterozoic Seridó Belt (Borborema Province, Brazil): constraints from U-Pb (SHRIMP) geochronology and implications forthe connections between NE Brazil and West Africa. Gondwana Research 23, 701-714.

Bautista, J.M.R., 2012. Estudo de proveniência sedimentar de sequências neoproterozóicas ao longo do Lineamento Patos (Província Borborema, NE Brasil). Dissertação de Mestrado, Instituto de Geociências, Universidade de São Paulo, 62 p.

Berek, M., 1924. Mikroskopische Mineralbestimmung mit Hilfe der Universaldrehtischmethode. Gebrüder Borntraeger, Berlin, 168 p.

Blenkinsop, T.G., 2000. Deformation microstructures and mechanisms in minerals and rocks. Springer Netherlands, $150 \mathrm{p}$.

Bouchez, J.L., 1978. Preferred orientations of quartz <a> axes in some tectonites: kinematic inferences. Tectonophysics 49, 25-30.

Cavalcante, J.C., Vasconcelos, A.M., Medeiros, M.F., Paiva, I.G., 2003. Mapa Geológico do Estado do Ceará. CPRM, Fortaleza, 1:500.000.

Corsini, M., Vauchez, A., Archanjo, C.J., Jardim de Sá, E.F., 1991. Strain transfer at a continental scale from a transcurrent shear zone to a transpressional fold belt: the PatosSeridó belt system, north-eastern Brazil. Geology 19, 586-589.

Corsini, M., Vauchez, A., Caby, R., 1996. Ductile duplexing at a bend of a continental-scale strike-slip shear zone: example from NE Brazil: Journal of Structural Geology 18 (4), 385394. 
Dantas, E.L., 1992. Evolução tectono-magmática do maciço polidiapírico São Vicente/Florânia - RN. Dissertação de Mestrado, Instituto de Geociências e Ciências Exatas, Universidade Estadual Paulista, 272 p.

Fetter, A.H., 1999. U-Pb and Sm-Nd geochronological constraints on the crustal framework and geologic history of Ceará State, NW Borborema Province, NE Brazil. PhD Thesis, Department of Geology, University of Kansas, 164 p.

Ganade de Araújo, C.E., Cordani, U.G., Basei, M., Castro, N., Sato, K., Sproesser, W.M., 2012. U-Pb detrital zircon provenance of metasedimentary rocks from the Ceará Central and Médio Coreaú Domains, Borborema Province, NE Brazil: tectonic implications for a long-lived Neoproterozoic active continental margin. Precambrian Research 207, 36-51.

Hackspacher, P.C., Van Schmus, W.R., Dantas, E.L., 1990. Um embasamento transamazônico na Provincia Borborema. XXXVI Congresso Brasileiro de Geologia, Natal, Anais, pp. 2683-2696.

Harley, S.L., Kelly, N.M., Moller, A., 2007. Zircon behaviour and thermal histories of mountain chains. Elements 3, 25-30.

Hausdorff, F., 1919. Dimension und äußeres Maß. Math. Ann. 79, 157-179.

Heilbronner, R.P., Pauli, C., 1993. Integrated spatial and orientation analysis of quartz caxis by computer-aided microscopy. Journal of Structural Geology 15, 369-382.

Higgins, M.D., 2006. Quantitative textural measurements in igneous and metamorphic petrology. Cambridge University Press, Cambridge, 276 p.

Hirth, G., Tullis, J., 1992. Dislocation creep regimes in quartz aggregates: Journal of Structural Geology 14 (2), 145-159.

Hobbs, B.E., Means, W.D., Williams, P.F., 1976. An outline of structural geology. Wiley, New York, 571 p.

Hollanda, M.H.B.M., Archanjo, C.J., Souza, L.C., Dunyi, L., Armstrong, R., 2011. Longlived paleoproterozoic granit magmatism in the Seridó-Jaguaribe domain, Borborema Province-NE Brazil. Journal of South American Earth Scienes 32, 287-300.

Hough, P.V.C., 1962. A method and means for recognizing complex patterns. U.S. Patent 3069654. 
Jardim de Sá, E.F., 1994. A Faixa Seridó (Província Borborema, NE do Brasil) e o seu significado geodynâmico na cadeia Brasiliana/Pan-Africana. Tese de Doutorado, Instituto de Geociências, Universidade de Brasilia, 804 p.

Jardim de Sá, E.F., Macedo, M.H.E., Fuck, R.A., Kawashita, K., 1992. Terrenos proterozóicos na Província Borborema e a margem norte do Gráton São Francisco. Revista Brasileira de Geociências 22 (4), 472-480.

Jessel, M.W., Lister, G.S., 1990. A simulation of the temperature dependence of quartz fabrics, vol. 54. Geological Society of London, Special Publications, pp. 353-362.

Kruhl, J.H., 1996. Prism- and basal-plane parallel subgrain boundaries in quartz: a microstructural geothermobarometer. Journal of Metamorphic Geology 14, 581-589.

Kruhl, J.H., 1998. Reply: prism- and basal-plane parallel subgrain boundaries in quartz a microstructural geothermobarometer. Journal of Metamorphic Geology 16, 142-146.

Kruhl, J., Nega, M., 1996. The fractal shape of sutured quartz grain boundaries: application as a geothermometer. Geol. Rundschau 85, 38-43.

Law, R.D., 2014. Deformation thermometry based on quartz c-axis fabrics and recrystallization microstructures: A review: Journal of Structural Geology 66, 129-161.

Legrand, J.M., Liegeois, J.P., Deutsch, S., 1991. Datação U/Pb e Rb/Sr das rochas précambrianas da região de Caicó - Reavaliação da definição de um embasamento arqueano. In: Simpósio de Geologia do Nordeste, 12, Recife, Atas, pp. 276-279.

Lister G.S., Willians P.F., 1979. Fabric development in shear zones, theorothical controls and observed phenomena. Journal of Structural Geology 1, 283-297.

Lister G.S., Hobbs B.E., 1980. The simulation of fabric development during plastic deformation and it's application to quartzite: the influence of deformation history. Journal of Structural Geology 2, 289-279.

Lloyd, G., Law, R., Schmid, S., 1987. A spherical electron channeling pattern map for use in quartz petrofabric analysis - correction and verification. Journal of StructuralGgeology 9 , 251-253.

Ludwig, K.R., 2003. Isoplot 3.00: A geochronological toolkit for Microsoft Excel, vol. 4. Berkeley Geochronological Center, Special Publ., Berkeley, CA, 70 p. 
Macedo, M.H.F., Sá, J.M., Jardim de Sá, E.F., Peucat, J.J., Souza, Z.S., Martin, H., 1991. Avaliação dos dados geocronológicos do complexo Caicó (RN) e suas implicações tectônicas. In: Simpósio de Geologia do Nordeste, 12, Recife, Atas, pp. 256-259.

Mainprice, D., Bouchez, J.L., Blumenfeld, P., Tubia, J.M., 1986. Dominant c-slip in naturally deformed quartz: implications for dramatic plastic softening at high temperature. Geology 14, 819-822.

Mandelbrot, B.B, 1983. The fractal geometry of nature. Henry Holt and Company, New York, $468 \mathrm{p}$.

Medeiros, V.C. (Org.), 2008. Geologia e recursos minerais da Folha Sousa: SB.24-X-A. CPRM, Recife, 1:250.000.

Monié, P., Caby, R., Arthaud, M.H., 1997. The Neoproterozoic Brasiliano orogeny innortheast Brazil: 40Ar/39Ar and petrostructural data from Ceará. Precambrian Research 81, 241-264.

Morales, L.F.G., Hinrichs, R., Fernandes, L.A.D., 2007. A técnica de difração de elétrons retro-espalhandos (EBSD) em microscópio eletrônico de varredura e sua aplicação no estudo de rochas deformadas. Revista Pesquisas em Geociências 34 (1), 19-34.

Morgan, S.S., Law, R.D., 2004. Unusual transition in quartzite dislocation creep regimes and crystal slip systems in the aureole of the Eureka Valley-Joshua Flat-Beer Creek pluton, California: a case for anhydrous conditions created by decarbonation reactions. Tectonophysics 384, 209-231.

Nascimento, R.S.C., Galindo, A.C., 2010. Relationships between shearing and granitic magma emplacement: the Remígio-Pocinhos shear zone in the São José de Campestre massif, NE Brazil. Geologia USP (Série científica) 10, 3-18.

Nicolas, A., Poirier, J.P., 1976. Crystalline plasticity and solid state flow in metamorphic rocks. Wiley-Interscience, London, $462 \mathrm{p}$.

Okudaira, T., Takeshita, T., Hara, I., Ando, J., 1995. A new estimate of the conditions for the transition from basal <a> to prism [c] slip in naturally deformed quartzite. Tectonophysics 250, 31-46.

Oliveira, R.G., 2008. Arcabouço geofísico, isostasia e causas do magmatismo cenozóico da Província Borborema e de sua margem continental (Nordeste do Brasil). Tese de Doutorado, Departamento de Geologia, Universidade Federal do Rio Grande do Norte, $411 \mathrm{p}$.

Passchier, C.W., Trouw, R.A.J., 2005. Microtectonics. Springer Berlin, Heidelberg, 382 p. 
Pidgeon, R.T., 1992. Recrystallisation of oscilatorry oned zircon: some geochronological and petrological implications. Contributions to Mineralogy and Petrology 110, 463-472.

Price G.P., 1985. Preferred orientations in quartzites. In: Wenk H.R. (Ed.), Preferred orientations in deformed metals and rocks: an introductions to modern texture analysis. Academic Press, Orlando, pp. 385-406.

Prior, D.J., Boyle, A.P., Brenker, F., Cheadle, M., Day, A., Lopez, G., Peruzzo, L., Potts, G.J., Reddy, S., Spiess, R., Timms, N.E., Trimby, P., Wheeler, J., Zetterström, L., 1999. The application of electron backscatter diffraction and orientation contrast imaging in the SEM to textural problems in rocks. American Mineralogist 84, 1741-1759.

Randle, V., Engler, O., 2000. Introduction to texture analysis: macrotexture, microtexture and orientation mapping. CRC, London, $408 \mathrm{p}$.

Sá, J.M., McReath, I., Leterrier, J., 1995. Petrology, geochemistry and geodynamic setting of Proterozoic igneous suites of the Orós fold belt (Borborema Province, Northeast Brazil). Journal of South American Earth Sciences 8 (3/4), 299-314.

Santoro, E., 1988. Evolução geológica do Pré-Cambriano da região de Santo Antônio do Pinhal, SP: importância tectônica das zonas de cisalhamento. Tese de Doutorado, Instituto de Geociênias, Universidade de São Paulo, 153 p.

Santos, E.J., 1996. Ensaio preliminar sobre terrenos e tectônica acrescionária na Província Borborema. XXXIX Congresso Brasileiro de Geologia, Salvador, Anais, pp. 47-50.

Santos, T.J.S., Fetter, A.H., Nogueira Neto, J.A., 2008. Comparisons between the northwestern Borborema Province, NE Brazil, and the southwestern Pharusian Dahomey Belt, SW Central Africa. In: Pankhurst, R.J., Trouw, R.A.J., Brito Neves, B.B., De Wit, M.J. (Eds.), West Gondwana: Pre-Cenozoic correlations across the South Atlantic Region, v. 294. Geological Society, Special Publications, pp. 101-119.

Sato, K., Siga Jr., O., Sproesser, W., Onoe, A.T., 2009. Excimer Laser (193 nm) acoplado ao ICP-MS Neptune: primeiros resultados de análises isotópicas "in situ"de U-Pb, Lu e Hf em zircão, monazita e xenotima no CPGeo-IGc-USP. Simpósio 45 Anos de Geocronologia no Brasil, São Paulo, Boletim de Resumos Expandidos, pp. 131-133.

Schmid, S.M., 1982. Microfabric studies as indicators of deformation mechanisms and flow laws operative in mountain building. In: Hsu, K.J. (Ed.), Mountain building processes. Academic Press, London, pp. 95-110.

Schmid, S.M., 1994. Textures of geological materials: computer model predictions versus empirical interpretation based on rock deformation experiments and field studies. In: Bunge 
H.J., Skrotski, W., Siegesmund, S., Weber, K. (Eds.), Textures of geological materials. DGM, Oberursel, pp. 278-301.

Schmid, S.M., Casey, M., 1986. Complete fabric analysis of some commonly observed quartz [c]-axis patterns. In: Hobbs, B.E., Heard, H.C. (Eds.), Mineral and rock deformation: laboratory studies. American Geophysical Union, Geophysical Monograph, pp. 263-286.

Schmidt, N.H., Olesen, N.O., 1989. Computer-aided determination of crystal-lattice orientation from electron-channeling patterns in the SEM. Canad. Mineral 27, 15-22.

Silva, L.C., McNaughton, N., Vasconcelos, A.M., Gomes, J.R.C., Fletcher, I.R.C., 1997. U$\mathrm{Pb}$ SHRIMP ages in the southern state of Ceará, Borborema Province, NE Brazil. II Internation Symposium on Granites and Associated Mineralizations (ISGAM), Salvador, Extended Abstract and Program, pp. 280-281.

Stipp, M., Stunitz, H., Heilbronner, R., Schmid, S.M., 2002. The eastern Tonale fault zone: a 'natural laboratory' for crystal plastic deformation of quartz over a temperature range from 250 to $700^{\circ} \mathrm{C}$. Journal of Structural Geology 24, 1861-1884.

Stoyan, D., 1994. Methods for empirical determination of fractal dimension. In: Stoyan, D., Stoyan, H. (Eds.), Fractals, random shapes and point fields. Wiley, New York, pp. 39-45.

Takeshita, T., Wenk, H.R., Lebensohn, R., 1999. Development of preferred orientation and microstructure in sheared quartzite: comparison of natural data and simulated results. Tectonophysics 312, 133-155.

Tapponier, P., Molnar, P., 1976. Slip-line field theory and large-scale continental tectonics. Nature 264, 319-324.

Tullis, J., 1977. Preferred orientation of quartz produced by slip during plane strain. Tectonophysics 39, 87-102.

Van Schmus, W.R., Brito Neves, B.B., Hackspacher, P., Babinski, M., 1995. U/Pb and $\mathrm{Sm} / \mathrm{Nd}$ geochronolgic studies of eastern Borborema Province, northeastern Brazil: initial conclusions. Journal of South American Earth Sciences 8, 267-288.

Van Schmus, W.R., Oliveira, E.P., da Silva Filho, A.F., Toteu, S.F., Penaye, J., Guimaraes, I.P., 2008. Proterozoic links between the Borborema Province, NE Brazil, and the Central African Fold Belt. In: Pankhurst, R.J., Trouw, R.A.J., Brito Neves, B.B., DeWit, M.J. (Eds.), West Gondwama: pre-cenozoic correlations across the South Atlantic Region, vol. 294. Geological Society of London, Special Publications, pp.69-99. 
Vauchez, A., Neves, S., Caby, R., Corsini, M., Egydio-Silva, M., Arthaud, M., Amaro, V., 1995. The Borborema shear zone system, NE Brazil: Journal of South American Earth Sciences 8 (3/4), 247-266.

Viegas, L.G.F., Archanjo, C., Vauchez, A., 2013. Fabrics of migmatites andthe relationships between partial melting and deformation in high-grade transpressional shear zones: the Espinho Branco anatexite (Bor-borema Province, NE Brazil). Journal of Structural Geology 48, 45-56.

Viegas, L.G.F., Archanjo, C.J., Hollanda, M.H.B.M., Vauchez, A., 2014. Microfabrics and zircon U-Pb (SHRIMP) chronology of mylonites from the Patos shear zone (Borborema Province, NE Brazil): Precambrian Research 243, 1-17.

Wahlstrom, E.E., 1969. Optical crystallography. Wiley, London, 489 p.

Wenk, H.R., Kern, H., Schaefer, W., Will, G., 1984. Comparison of neutron and X-ray diffraction in texture analysis of deformed carbonate rocks. Journal of Structural Geology 6, 687-692.

Wenk, H.R., Bunge, H.J., Jansen, E., Pannetier, J., 1986. Preferred orientation of plagioclase-neutron diffraction and U-stage data. Tectonophysics 126, 271-284.

Wilson, C.J.L., Russell-Head, D.S., Sim, H.M., 2003. The application of an automated FA system to the textural evolution of folded ice layers in shear zones. Annals of Glaciology $37,7-17$.

Wilson, C.J.L., Russell-Head, D.S., Kunze, K., Viola, G., 2007. The analysis of quartz caxis fabrics using a modified optical microscope. Journal of Microscopy 227, 30-41. 
ANEXO A 